Universidade de SÃo PaUlo

Faculdade de Filosofia, Letras e Ciências Humanas

Departamento de Letras Clássicas e Vernáculas

Programa de Pós-graduação em Filologia e Língua Portuguesa

Alfredo Christofoletti Silveira

Ditongos no Português de São Tomé e Príncipe

(versão corrigida) 
Universidade DE SÃo PAUlo

Faculdade de Filosofia, Letras e Ciências Humanas

Departamento de Letras Clássicas e Vernáculas

Programa de Pós-graduação em Filologia e Língua Portuguesa

Alfredo Christofoletti Silveira

\section{Ditongos no Português de São Tomé e Príncipe}

(versão corrigida)

Dissertação apresentada ao Programa de Pós-graduação em Filologia e Língua Portuguesa do Departamento de Letras Clássicas e Vernáculas da Faculdade de Filosofia, Letras e Ciências Humanas da Universidade de São Paulo, como requisito parcial para a obtenção do título de Mestre em Filologia e Língua Portuguesa.

Orientador: Prof. Dr. Gabriel Antunes de Araújo 
Autorizo a reprodução e divulgação total ou parcial deste trabalho, por qualquer meio convencional ou eletrônico, para fins de estudo e pesquisa, desde que citada a fonte.

Catalogação na Publicação

Serviço de Biblioteca e Documentação

Faculdade de Filosofia, Letras e Ciências Humanas da Universidade de São Paulo

Christofoletti, Alfredo

Ditongos no Português de são Tomé e Príncipe (versão corrigida) / Alfredo Christofoletti ; orientador Gabriel Antunes de Araujo. - São Paulo, 2013.

$108 \mathrm{f}$.

Dissertação (Mestrado) - Faculdade de Filosofia, Letras e Ciências Humanas da Universidade de São Paulo. Departamento de Letras Clássicas e Vernáculas. Área de concentração: Filologia e Língua Portuguesa.

1. Ditongo. 2. Fonética. 3. Fonologia. 4. Sociolinguística. 5. Língua Portuguesa. I. Araujo, Gabriel Antunes de, orient. II. Título. 


\section{Sumário}

Agradecimentos .............................. $\mathrm{V}$

Resumo ................................ vii

Abstract . . . . . . . . . . . . . . . . . . . . . viii

Lista de Abreviaturas . . . . . . . . . . . . . . . . . . . . . . . . ix

1 Introdução 1

1.1 Apresentação . . . . . . . . . . . . . . . . . . . . . . . . . . . . . . 1

1.2 Objeto de estudo: o português vernacular são-tomense . . . . . . . . . . . . . 4

1.3 As línguas de São Tomé e Príncipe . . . . . . . . . . . . . . . . . . . . . . 8

1.3.1 Fator Histórico . . . . . . . . . . . . . . . . . . . . . . 8

1.3.2 As línguas autóctones . . . . . . . . . . . . . . . . 12

1.3.3 A situação da línguas autóctones na sociedade são-tomense . . . . . 15

1.3.4 O português em São Tomé e Príncipe . . . . . . . . . . . . . . . . . 17

1.4 Métodos de coleta e classificação do corpus . . . . . . . . . . . . . . . . . 19

1.4.1 Variável linguística dependente . . . . . . . . . . . . . . . . . 24

1.4.2 Variáveis linguísticas independentes . . . . . . . . . . . . 25

1.5 Prolegômenos ao uso dos dados estatísticos variacionistas . . . . . . . . . . 27

2 Os ditongos $\quad 30$

2.1 Alguns aspectos da fonologia das línguas nacionais de STP . . . . . . . . . 30

2.1.1 Restrição à coda . . . . . . . . . . . . . . . . . . . . . . . 31

2.1.2 Processos fonológicos das palavras com ditongos . . . . . . . . . 33

2.2 O sistema vocálico do PVS . . . . . . . . . . . . . . . . . . . . . . 36

2.3 Interpretações sobre os ditongos no português . . . . . . . . . . . . . . . . . . 42

2.4 Realização de ditongos em algumas variedades do português . . . . . . . . . . 49

3 Discussão e análise dos dados $\quad 59$

3.1 Introdução . . . . . . . . . . . . . . . . . . . . . . . . . . . 59

3.2 A análise .. . . . . . . . . . . . . . . . . . . . . 59

3.3 Ditongos ............................. 61

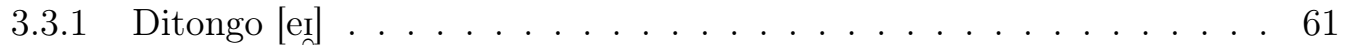

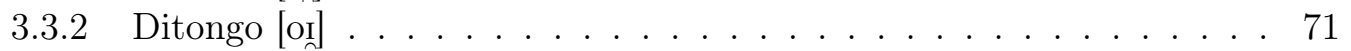

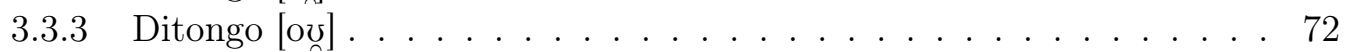

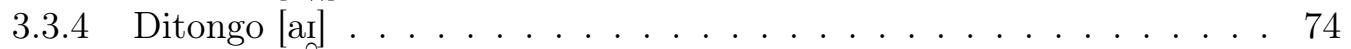

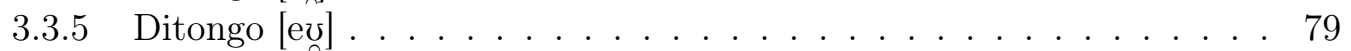

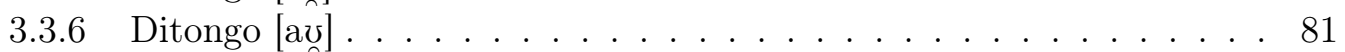

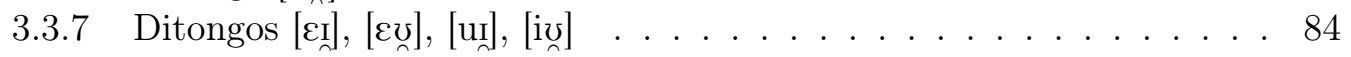

4 Considerações finais $\quad 86$

5 Referências bibliográficas $\quad 91$

$\begin{array}{lr}\text { A Corpus } & 97\end{array}$ 
When we study language and social dialects, it's hard to say that there's anything that people cannot or never will do. Given the right social circumstances, they'll do it. - Labov, W. (2006) 


\section{Agradecimentos}

Começo por agradecer ao Prof. Gabriel Antunes de Araujo que me acompanha como orientador e amigo desde a Iniciação Científica. Seu empenho e dedicação foram fundamentais não só para o desenvolvimento dessa pesquisa, mas principalmente no meu crescimento e amadurecimento como pesquisador.

A minha família que me apoia sempre, apesar de eu ser um filho muitas vezes distante.

Agradeço à FAPESP, fundação que fomenta minhas pesquisas desde a Iniciação Científica. Especiais agradecimentos à USP, especificamente à Superintendência de Assistência Social, pois sem seus apoios com moradia, alimentação e bolsas trabalho, eu mal teria terminado a graduação.

A todos meus informantes e às pessoas envolvidas durante minhas estadias em São Tomé e Príncipe, principalmente à Santa Casa de Misericórdia e o apoio total recebido da Embaixada do Brasil em STP, lugares onde fiz amigos muito queridos. Também ao Liceu Nacional e Instituto Superior Politécnico.

A todos meus professores desde a graduação, especialmente ao Prof. Dr. Mario Viaro e à Prof. Dra. Rosane de Sá Amado pelas anotações e observações feitas na banca de qualificação.

Ao apartamento 304-A e todos os envolvidos, lugar especial do Conjunto Residencial da USP no qual vivi durante toda graduação e mestrado e personagem principal na construção das amizades e no meu desenvolvimento nas mais diversas áreas da vida.

Agradeço ao Grupo de Estudos de Línguas em Contato (GELIC) pelas intervenções feitas durante os encontros, assim como pela oportunidade de participar de um grupo tão competente e amistoso. Em especial aos integrantes e amigos Ana Lívia, Eduardo Santos, Manuele Bandeira e Gabriela Braga, os quais me ajudaram com observações e 
sugestões para aprimorar o presente trabalho e especialmente à Shirley Freitas, cuja revisão e colaboração na etapa final dessa dissertação foram valorosas e imprescindíveis.

À Marina Thaler Machado, pelo apoio, carinho e paciência durante a tensa reta final deste percurso.

À Prof. Dra. Flaviane Romani Fernandes Svartman e à Prof. Dra. Silvia Figueiredo Brandão, pelas valorosas observações e sugestões durante a defesa dessa dissertação.

Ainda assim, todos os equívocos que ainda permanecerem são de minha inteira responsabilidade. 


\section{Resumo}

O objeto deste trabalho é investigar a realização dos ditongos orais no português vernacular de São Tomé e Príncipe (PVs). Esta variedade de português está em contato com outras línguas faladas no país e difere do sistema linguístico da variedade considerada padrão, o português europeu (PE) (FIGUEIREDO, 2010; GONÇALVES, 2010; CHRISTOFOLETTI, 2011; SANTOS \& CHRISTOFOLETTI, 2011). A hipótese para as peculiaridades do comportamento do sistema fonético-fonológico do PVS é o aprendizado do português como L2 (por gerações passadas recentes) (HAGEMEIJER, 2009; GONÇALVES, 2010), e a influência do contato com as línguas crioulas faladas no país, como o santome (FERRAZ, 1979), o principense (MAURER, 2009), o angolar (MAURER, 1995) e o kabuverdianu, visto que as comunidades são, em geral, bilíngues ou convivem em espaços multilíngues. As mudanças linguísticas intergeracionais e o contato também justificariam o comportamento na realização dos ditongos que possuem variações em sua realização no PVS.

O corpus deste trabalho é formado por gravações de fala espontânea de 18 informantes, coletados na capital de STP por meio da sociolinguística variacionista (LABOV, 1991 [1972]). A justificativa para o estudo das realizações dos ditongos, constatada a singularidade de suas realizações, é observar o comportamento de uma variante de português em um ambiente multilíngue; aumentar o nosso conhecimento sobre essa variante; confrontar um sistema em diglossia; possibilitar outros estudos sobre o PVS e comparações com outras variantes de português nos Países Africanos de Língua Oficial Portuguesa. Em relação às variáveis sociais, há uma relação da aplicação do processo de monotongação com a quantidade de anos de escolaridade, sendo que as pessoas mais escolarizadas tendem evitar mais a monotongação do que as pessoas menos escolarizadas. Ademais, foi constatada a singularidade do sistema fonético-fonológico dessa variedade africana de português, pois, diferente da norma europeia (MATEUS \& D'ANDRADE, 2000; MATEUS, 2002), considerada de prestígio no país, o PVS realiza a monotongação dos ditongos [eI], como em "dinheiro" [di'nевъ], "primeiro" [pri'mеь»] е "feijoada" [fezu'adø], sugerindo uma aproximação ao comportamento do português brasileiro (PB) (cf. BISOL 1991, 1994; ARAÚJO 1999; LOPES 2002 e outros), todavia, a monotongação ocorre ainda em contextos nos quais tanto nas variantes do PB, como nas do PE, ela é bloqueada. Assim, ocorre a monotongação mesmo quando a consoante seguinte é uma oclusiva alveolar surda [t], como em "feitiço" [fe'tiss]], "leitão" [le'tãon] e "direito" [di'setv], fato não documentado no PB ou no PE. Com relação ao ditongo [ov] no PVs, a monotongação é categórica, assim como nos estudos apresentados sobre variação nos ditongos de outras variedades de português. No que diz respeito ao ditongo [oI], observamos que a variação na aplicação da monotongação ocorre apenas quando seguido pela consoante $\left[\int\right]$, responsável pelo espraiamento do nó vocálico criando o glide [I] via processo fonético. O ditongo [aI], por sua vez, sofreu variação no processo de monotongação fundamentalmente diante de consoante palatal, nos demais contextos sua ocorrência foi pouco produtiva. Do mesmo modo, o ditongo [ev] teve baixo índice de ocorrência de

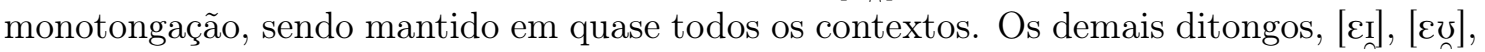
[uI] e [ivo], tiveram raras ocorrências, e foi impossível observar variações em suas realizações.

Palavras-chave: Ditongos, Fonética e Fonologia, Português, Sociolinguística, São Tomé e Príncipe. 


\section{Abstract}

The purpose of this work is to investigate the realization of oral diphthongs in vernacular portuguese of Sao Tome and Principe (PVS). This variety of portuguese is in contact with other languages spoken in the country and differs from the linguistic system of the considered standard variety, the european portuguese (PE) (FIGUEIREDO, 2010; GONÇALVES, 2010; CHRISTOFOLETTI, 2011; SANTOS \& CHRISTOFOLETTI, 2011). The hypothesis for the behavior of the phonetic-phonological system of PVs is the learning of portuguese as L2 (from recent past generations) (HAGEMEIJER, 2009; GONÇALVES, 2010), and the influence of contact with the creole languages spoken in the country, as the santome (FERRAZ, 1979), the principense (MAURER, 2009), angolar (MAURER, 1995) and kabuverdianu, since the communities are usually bilingual or living in multilingual environment. The intergenerational linguistic changes and the linguistic contact also justify the behavior in the realization of diphthongs that have variations in their realization in PVS. The corpus of this study consists of recordings of spontaneous speech of 18 informants, collected in the capital of STP through the assumptions of sociolinguistic theory and method (LABOV, 1991 [1972]). The reason to study the achievements of diphthongs, noted the uniqueness of its accomplishments, is to observe the behavior of a variant from portuguese in a multilingual environment; increase our knowledge of this variant; confront a system in diglossia; enable further studies on the PVS and compare it with other variants in the African countries witch have portuguese as official language. Regarding social variables, there is a link to the application of the process of monophthongization with the number of years of schooling, once that people with more time of school education tend to avoid monophthongization than people with less time of school education. Moreover, it was found the uniqueness of the phonetic-phonological system of PVS, because, unlike the PE (MATEUS \& D'ANDRADE, 2000; MATEUS, 2002), considered prestigious in the country, PVs performs the monophthongization of diphthongs [eI], as seeing in "dinheiro" [di'левv], "primeiro" [рri'тевv] and "feijoada" [fezu'ade], it suggests an approach to behavior of Brazilian portuguese (PB) (cf. BISOL 1991, 1994; ARAÚJO 1999; LOPES 2002 e outros), however, monophthongization still occurs in contexts in both the variants whrer it is blocked as PB, as in the PE. So monophthongization occurs even when the following consonant is an voiceless alveolar occlusive [t], as in "feitiço" [fe'tisv], "leitão" [le'tã z్ e "direito" [di'setv], nons-documented fact in PB or PE. Regarding the diphthong [ov] in PVS the monophthongization is categorical, as shown in studies on diphthong's variation in other varieties of portuguese. With respect to the diphthong [oI] we observed that the variation in the application of monophthongization occurs only when it followed by the consonant $[\delta]$, responsible for spreading the vocalic feature creating the glide [I] through phonetic process. The diphthong [aI] suffered variation in the monophthongization process, mainly before palatal consonant, in other contexts its occurrence was not very productive. Similarly, the diphthong [ev] had a low rate of occurrence of monophthongization, and

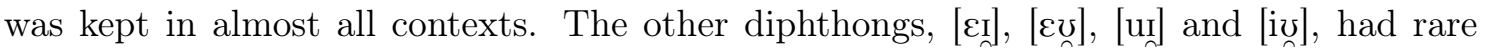
occurrences, and it was impossible to observe variations in their realizations.

Keywords: Diphthongs, phonetics and phonology, Portuguese, Sociolinguistics, Sao Tome and Principe. 


\section{Lista de Abreviaturas}

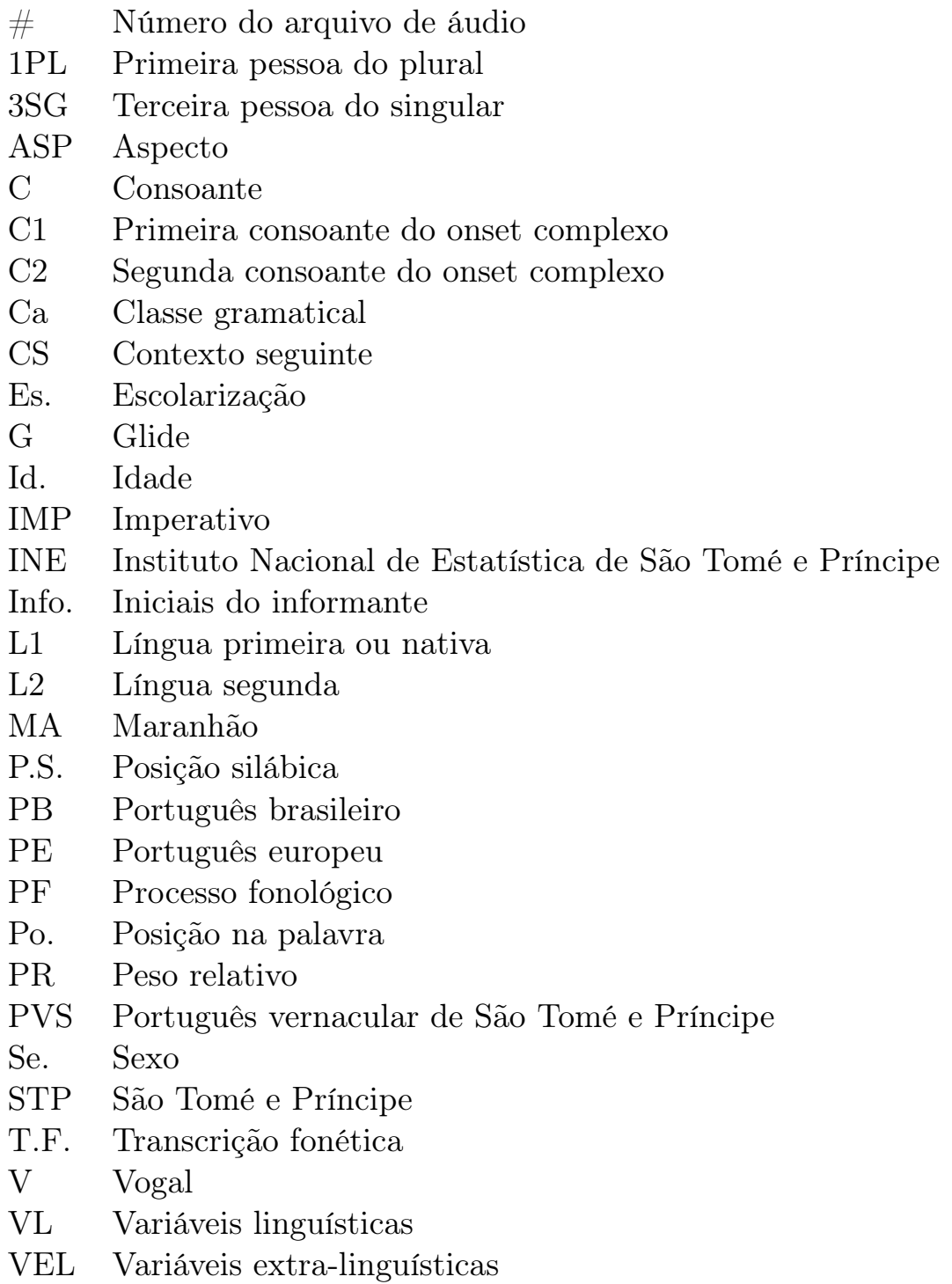




\section{Lista de Tabelas}

1.1 Número de falantes em cada censo de acordo com as línguas faladas em STP. . 6

3.1 Número de ocorrências para cada ditongo presente no corpus. . . . . . . . . . . 60

3.2 Aplicação da monotongação do [eI] cf. contexto fonético seguinte. . . . . . . . . . 65

3.3 Comparativo entre o PVS e o PB do Rio de Janeiro. . . . . . . . . . . . . . . 66

3.4 Porcentagem e peso relativo da variável classe da palavra [eı]. . . . . . . . . . 67

3.5 Resultados da variável posição do ditongo [eI] . . . . . . . . . . . . . . . . . . 68

3.6 Resultados da variável número de sílabas para o ditongo [eI]. . . . . . . . . . . . 68

3.7 Resultados da variável escolaridade do ditongo [e

3.8 Resultados da variável Idade do ditongo [eı $\ldots$. . . . . . . . . . . . . . . . . . 70

3.9 Palavras mais frequentes contendo o ditongo [or] . . . . . . . . . . . . . . . 72

3.10 Aplicação da monotongação do [aI] cf. contexto fonético seguinte na primeira rodada. . . . . . . . . . . . . . . . . . . . 75

3.11 Aplicação da monotongação do [aI] cf. classe de palavra. . . . . . . . . . . . 76

3.12 Aplicação da monotongação do [aI] cf. contexto fonético seguinte na segunda

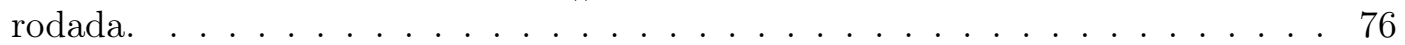

3.13 Aplicação da monotongação do [aI] cf. contexto fonético seguinte na segunda rodada. . . . . . . . . . . . . . . . . . 76

3.14 Resultados da variável escolaridade do ditongo [ar] . . . . . . . . . . . . . 77

3.15 Resultados da variável idade do ditongo [ar]. . . . . . . . . . . . . . . . . . 78 


\section{Lista de Quadros}

1 Quadro de exemplos de vogais tônicas. . . . . . . . . . . . . . . . . . 38

2 Quadro indicador das variáveis ligadas a monotongação. . . . . . . . . . . . 90

\section{Lista de Figuras}

1.1 Localização geográfica da República Democrática de São Tomé e Príncipe. . . . 1

1.2 São Tomé, capital da República Democrática de São Tomé e Príncipe. . . . . . 2

1.3 Porcentagem da população de acordo com a língua falada, INE (2012). . . . . . 7

1.4 Diagrama de falantes classificados de acordo com as variáveis sociais. . . . . . . 22

2.1 Criação do glide pelo espraiamento do nó vocálico do tepe. . . . . . . . . . . . 47

3.1 Comparação das variáveis escolaridade e idade na monotongação de [eI] (pesos relativos). . . . . . . . . . . . . . . . . . . . 70

3.2 Comparação das variáveis escolaridade e idade na monotongação de [aı] (pesos relativos). . . . . . . . . . . . . . . . . . 78

4.1 Atuação da variável escolaridade para a monotongação de [eI ] e [aI] (pesos relativos). . . . . . . . . . . . . . . . . . . . . . 87 


\section{Capítulo 1}

\section{Introdução}

\subsection{Apresentação}

A República Democrática de São Tomé e Príncipe localiza-se na costa ocidental do continente africano, mais precisamente em um região denominada Golfo da Guiné, na altura da linha do Equador, como visto na Figura 1.1:

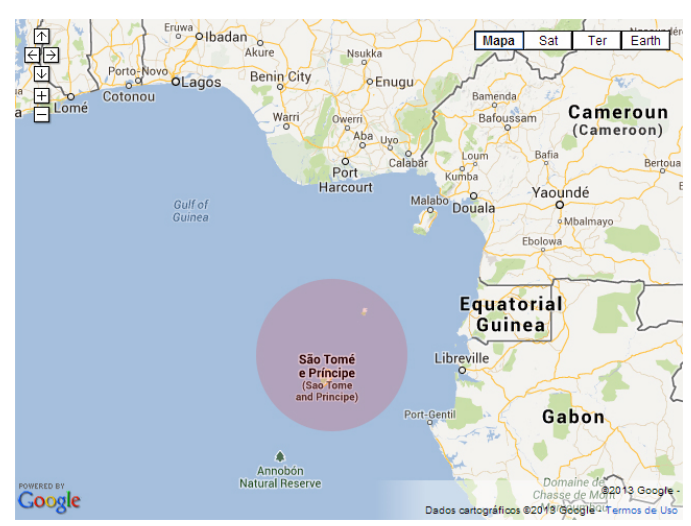

Figura 1.1: Localização geográfica da República Democrática de São Tomé e Príncipe.

O presente trabalho busca analisar as realizações dos ditongos do português popular de São Tomé, capital da República de São Tomé e Príncipe (STP) (Figura 1.2), doravante português vernacular são-tomense (PVS), por meio da sociolinguística variacionista. Como objetivo específico, investigamos os ditongos orais realizados no PVS, visando identificar se ocorre, ou não, processos de monotongação, além de observar quais variáveis, linguísticas 
e extralinguísticas, podem influenciar o fenômeno. Por hipótese, sustentamos que a realização dos ditongos, nessa variedade, difere das realizações do Português Europeu (PE), padrão normativo em STP. Em STP, além do português, são faladas outras quatro línguas crioulas $^{1}$, a saber: o santome (forro), o lung'ie (principense), o angolar e o kabuverdianu ${ }^{2}$, as quais se encontram em contato com o PVS. Essas línguas não possuem ditongos em sua fonologia ou os possuem de forma limitada, ou seja, possuem apenas ditongos crescentes. A partir disso, defenderemos que esse ambiente de contato linguístico possa estar influenciando o processo de monotongação ${ }^{3}$ no PVS. Destarte, esta dissertação procura cumprir o objetivo geral de contribuir com os estudos do PVs nos campos da fonética, fonologia e sociolinguística, dando continuidade à pesquisa "O sistema vocálico do português vernacular de São Tomé e Príncipe" (CHRISTOFOLETTI, 2010) e fornecer material para pesquisas futuras nessas e em outras áreas da Linguística que permitam investigar os efeitos do contato entre as diversas línguas presentes em STP.

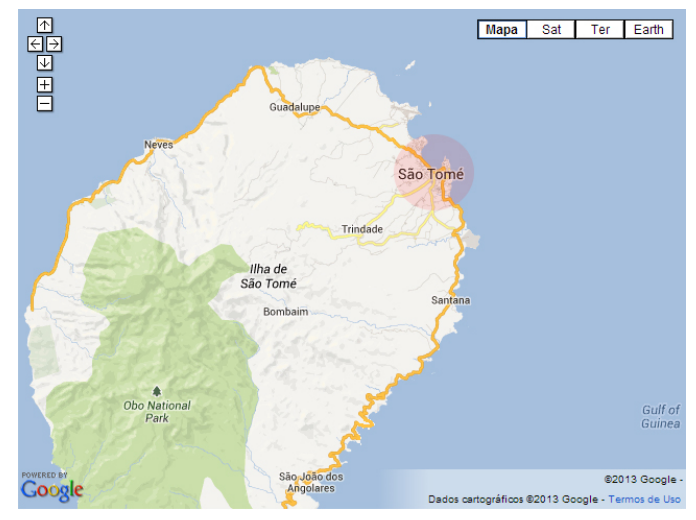

Figura 1.2: São Tomé, capital da República Democrática de São Tomé e Príncipe.

Nos últimos anos, observa-se uma ampliação nos estudos das variedades do português

${ }^{1}$ O termo "língua crioula" é utilizado neste trabalho sob o ponto de vista da característica singular da gênese dessas línguas, a qual envolve fatores sócio-históricos distintos que serão detalhados na subseção 1.3.1.

${ }^{2}$ Sobre o nome das línguas, consultar Holm \& Madeira (2009).

3 "fenômeno fonológico em que um ditongo passa a ser produzido como uma única vogal"(SILVA, 2011) 
na África (ANÇÃ, 2002; BACELAR DO NASCIMENTO et al., 2006; AFONSO, 2007, 2008; ALEXANDRE et al., 2010; entre outros), todavia são ainda poucos os que tratam das variedades vernáculas, aquelas usadas pela maioria da população em seu dia a dia (FIGUEIREDO, 2008, 2009, 2010, 2012; GONÇALVES, 2010a, 2010b; CHRISTOFOLETTI, 2011; SANTOS \& CHRISTOFOLETTI, 2011). Somado a isso, por uma série de fatores, há mais estudos sobre as variedades angolana e moçambicana, restando um amplo campo a ser estudado nos outros países africanos de língua oficial portuguesa, como São Tomé e Príncipe, Guiné-Bissau e Cabo Verde. Estudar as variedades africanas do português fazse importante na medida em que o conhecimento de seu comportamento nesse contexto sócio-histórico ajuda a entender o funcionamento da língua portuguesa em suas diversas variedades.

O foco da dissertação é uma investigação sobre a realização dos ditongos no PVs, pois segundo Couto (1994: 129), "os ditongos são a chave para se resolverem algumas das questões mais complicadas da fonologia da língua portuguesa". Entendemos que as questões ligadas aos ditongos são importantes, posto que os glides em sua margem influenciam as consoantes e vogais, bem como a interação desses com a estrutura silábica da língua. Assim, a observação dos ditongos pode trazer pistas que auxiliar-nos-ão nas investigações da estrutura fonológica dessa e de outras variedades de Português, principalmente aquelas cujo ambiente é de contato linguístico. Os resultados desse estudo podem ser importantes, pois:

i. fornecem informações sobre processos fonológicos de uma variedade de português pouco estudada;

ii. possibilitam observar o comportamento da língua portuguesa em ambientes plurilíngues; 
iii. trazem novos dados empíricos para a teoria dos ditongos nas variedades de português;

iv. proporcionam material para novos estudos dessa variedade africana de português por meio do corpus construído.

Para cumprir os objetivos desse trabalho, foi coletado um corpus, de falas espontâneas coletadas em STP durante visitas realizadas entre 2009 e 2011. O material foi coletado e analisado sob a ótica da sociolinguística variacionista (cf. Labov 1991 [1972]). A partir das gravações, foi constituído um corpus contendo palavras que contivessem ditongos em sua forma subjacente. Assim, foi feita a análise dos processos fonológicos com o intuito de se obter evidências de quais contextos e variáveis (linguísticas ou extra-linguísticas) poderiam estar influenciando a realização variável dos ditongos, isto é, se o ditongo era realizado de forma plena ou se sofria processos de monotongação. Para tanto, os dados classificados foram tratados por meio de padrões estatísticos gerados pelo programa Goldvarb 2001 (ROBINSON, LAWRENCE \& TAGLIAMONTE, 2001).

O presente trabalho está organizado da seguinte forma: neste capítulo introdutório apresentamos o objeto de estudo, a situação das línguas existentes em São Tomé e Príncipe, os métodos de coleta e classificação do corpus, e uma introdução ao uso dos dados estatísticos variacionista. No capítulo 2, faremos a síntese da bibliografia dos ditongos no português. No capítulo 3, apresentaremos a discussão e análise dos dados e, no capítulo 4, as considerações finais.

\subsection{Objeto de estudo: o português vernacular são-tomense}

Apresentaremos nesta seção algumas questões relacionadas ao português vernacular sãotomense e ao quadro linguístico atual de STP. Na seção seguinte, partiremos do fator 
histórico para observar como surgiram as diversas línguas presentes na ilha. Posteriormente, por meio de dados estatísticos fornecidos pelo INE $(2001,2012)$, veremos como o português passa a ser gradualmente mais utilizado em relação à segunda língua mais falada em STP, o santome, em consequência de fatores históricos recentes. Ao fim, discutiremos como o processo de aquisição e o contato com as outras línguas pode ter dado ao PVS características singulares no que concerne à realização dos ditongos, uma vez que estudos sobre a sintaxe do PVS já demonstraram a influência do santome na variedade de português falado em STP (cf. FIGUEIREDO, 2008, 2009, 2010 e GONÇALVES, 2010a, 2010b).

Os dados oficiais utilizados nesta seção são do último censo aplicado no país em 2011. O censo de STP além de colher dados demográficos, também colhe dados sobre as línguas faladas no país. Assim, embora não seja informado o teor da pergunta (qual língua você fala, quais?, quando e onde aprendeu? etc.), os dados ajudam a compreender a situação linguística dos são-tomenses. Utilizaremos também dados dos censos anteriores (1981, 1991 e 2001) como forma de comparação. É fundamental recorrer a estas informações, pois elas trazem sinais para a observação da situação das diversas línguas dentro do espaço geográfico da Ilha. Os dados dos censos mais recentes, de 2001 e 2011, não nos permitem saber se as línguas foram adquiridas/usadas como língua materna (L1) ou como língua aprendida posteriormente à aquisição (L2), uma vez que essas informações não foram inseridas no relatório explicativo sobre o censo. Além disso, os resultados são inclusivos, ou seja, pessoas que falam português podem também falar outras línguas, isso significa que os índices revelam um ambiente de multiliguismo, uma vez que a pessoa pode falar o português e outras línguas ao mesmo tempo. Os resultados de 2011 são diferentes dos obtidos no censo de 2001, o qual indicou o português sendo falado por 98,9\% da população, seguido pelo santome, com $72,4 \%$ do total de habitantes. Na ocasião do recenseamento feito em 2001, o questionário aplicado incluía o português, o francês, o santome, o lung'ie 
e um item denominado "Outros", enquanto que no censo de 2011, foram incluídas as opções inglês, kabuverdianu e angolar, proporcionando maior precisão sobre a situação das demais línguas crioulas faladas no país, além do santome e do lung’ie. Segundo o censo de 2011 (INE, 2012), a língua portuguesa ainda é falada pela maioria da população (90,9\%), seguida pelo santome, falado por $33,6 \%$.

A queda de quase dez por cento no número de falantes de português entre o censo de 2001 (98,9\% de uma população de 137.599) e o censo de 2011 (90,1\% de 187.356) nos é estranho, pois não houve evento durante esse período que justificasse esse resultado, já que nas últimas décadas a língua portuguesa em São Tomé e Príncipe vinha sendo gradualmente mais utilizada em detrimento das demais línguas faladas no país. Gonçalves (2010a), por meio de informações dos três recenseamentos pós-independência (1981, 1991 e 2001 respectivamente), observou que o número de falantes de português aumentou consideravelmente desde o primeiro censo de 1981 (60.519 falantes) até o penúltimo de 2001 (136.085 falantes), evidenciando o uso do português como principal língua utilizada pela população (o número de falantes em 2011 subiu para 170.306). No site do INE5 há um aviso alertando que os dados de 2011 exibidos ainda são preliminares e sujeitos à verificação.

\begin{tabular}{lllllllll}
\hline Censo & $\begin{array}{l}\text { Portu- } \\
\text { guês }\end{array}$ & Forro & \multicolumn{2}{l}{$\begin{array}{l}\text { Kabu- } \\
\text { verdianu }\end{array}$} & Francês Inglês & Outra & Lung'ie Angolar \\
1981 & 60.519 & 54.387 & - & 521 & - & 8.180 & 1.533 & - \\
1991 & 94.907 & 69.899 & - & 3.896 & - & 12.781 & 1.558 & - \\
2001 & 136.085 & 99.621 & - & 9.319 & - & 17.612 & 3.302 & - \\
2011 & 170.309 & 62.889 & 14.725 & 11.759 & 8.605 & 4.224 & 1.760 & 1.217 \\
\hline
\end{tabular}

Tabela 1.1: Número de falantes em cada censo de acordo com as línguas faladas em STP.

A Figura 1.3 apresenta a distribuição das línguas e número de falantes em STP, segundo o censo de 2011. Ao comparar a Figura 1.3 com a Tabela 1.1, observa-se uma discrepância

${ }^{4}$ Esse item se refere às "línguas estrangeiras e não estrangeiras, utilizadas pela população no mosaico linguístico característico do país" (INE, 2001: 48).

${ }^{5}$ http://www.ine.st/docs/2012/Censos/2012/index.html 
acentuada entre os censos de 2001 e 2011 no número de falantes de santome. Em 2001, 99.621 falantes representavam 72,4\% da população do país; no censo de 2011, esse número caiu para 33,6\% (62.889 falantes) do total de habitantes. Novamente, não houve nenhum acontecimento que justificasse essa queda, sendo a causa, possivelmente, um problema de diferentes metodologias na aplicação do censo.

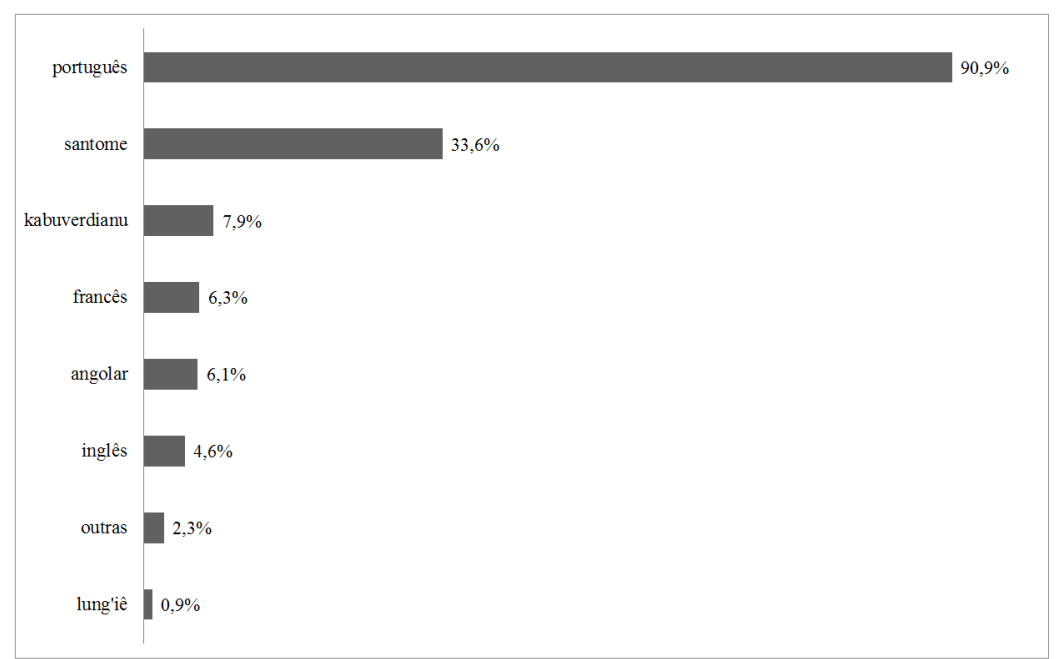

Figura 1.3: Porcentagem da população de acordo com a língua falada, INE (2012).

Por meio da Figura 1.3, ainda podemos notar que o kabuverdianu é a terceira em número de falantes no país, apesar de ser uma língua trazida por meio da contratação de mão-de-obra cabo-verdiana em meados do século XX. A língua francesa em quarto lugar indica que na ocasião do censo não houve a preocupação em se obter informações sobre a forma de aquisição e domínio das línguas faladas pelos habitantes, pois o francês é disciplina presente no currículo escolar, assim como o inglês. Durante o trabalho de campo no país, não foi constatado o uso oral da língua francesa, tampouco da inglesa, no dia a dia dos habitantes. 


\subsection{As línguas de São Tomé e Príncipe}

São Tomé e Príncipe é um país plurilíngue, assim, faz-se necessária uma pequena introdução sobre as línguas mais faladas nesse país. Iniciaremos pelos fatores históricos da formação do país, essenciais para o entendimento da presença da língua portuguesa e do surgimento das línguas locais. Em seguida, apresentaremos uma breve descrição de cada língua autóctone.

\subsubsection{Fator Histórico}

A ocupação de São Tomé e Príncipe passa por dois principais momentos históricos distintos: a primeira fase do povoamento motivado pelo cultivo e produção do açúcar por meio de atividade escravocrata, nos séculos XV e XVI; e a fase dos "contratados" para o ciclo do café e do cacau, nos séculos XIX e XX (HAGEMEIJER, 2009). As ilhas, antes desabitadas, começam a ser povoadas na segunda metade do século XV pelos portugueses (LORENZINO, 1996; HAGEMEIJER, 2009), os quais traziam africanos, provenientes de vários pontos do continente, para servirem como mão de obra e darem início às plantações de cana-de-açúcar. Assim, é formada na ilha de São Tomé uma nova sociedade composta por culturas e línguas diversas.

Durante a primeira fase de ocupação, os africanos provinham principalmente de regiões como o delta do Níger, onde se falam línguas do grupo edo, e do Congo e Angola, onde se falam línguas do grupo bantu. O amálgama constituído pela situação de contato entre as diversas línguas faladas pelos africanos e a língua portuguesa falada pelo colonizador, o sistema escravocrata e o ambiente "ilha", fez com que o momento se tornasse ideal para o surgimento de uma nova língua. Essa língua, formada nesse contexto, apesar de ser linguisticamente semelhante a qualquer outra, tem, em seu rápido surgimento, aspectos sócio-históricos comuns a outras línguas surgidas em contextos similares (cf. ARENDS et al., 1995). Em situações de contato parecidas, podem surgir dois tipos de língua: os 
pidgins e os crioulos. Os pidgins servem como código emergencial em sociedades compostas por falantes de diversas línguas ininteligíveis e surgem para funcionar como meio de comunicação básica, geralmente restrita para apoiar algum tipo de contato instantâneo e temporário (DE CAMP, 1971 apud FIGUEIREDO, 2010). Para Muysken e Smith (1995), os pidgins se caracterizam por serem códigos utilizados entre falantes de línguas distintas entre si e por não ser língua nativa de nenhum falante.

As línguas crioulas devem ser consideradas naturais como outras línguas. No entanto, sua gênese segue um padrão observável em todo o Atlântico, sendo necessário notar não apenas suas marcas gramaticais, mas também o processo histórico envolvido em sua criação. Araujo (2011) cita alguns dos elementos favorecedores para o surgimento de uma língua crioula, desde que membros de comunidades de fala diferentes sejam confinados:

i. Ambiente "ilha": não necessariamente uma ilha geográfica, mas um local isolado, que não permita livre movimentação dos indivíduos;

ii. Relação demográfica entre grupos étnicos de dominados/controlados e entre estes grupos e os colonizadores: uma vez que, dentro do ambiente acima descrito, existem várias línguas e, dentre elas, nenhuma com representação demográfica relevante ao ponto de se tornar maioritária, manifesta-se a necessidade de se criar um código de comunicação emergencial. Se houver um grupo étnico em número muito superior aos demais, os grupos minoritários tenderão a usar a língua da maioria. Assim, a disparidade na relação entre as várias línguas dos dominados torna-se um fator importante para o surgimento de uma língua crioula. A relação dos grupos de escravizados, no mundo colonial português, com os colonizadores também é fundamental, verificado o sistema de estratificação social do sistema escravocrata (i.e. aqueles que trabalham na casa-grande têm mais contato com a língua do colonizador, enquanto os que trabalham nas plantações possuem contato menor ou nenhum), o qual perfaz com que 
a transmissão da língua-alvo (língua do colonizador) seja feita de forma múltipla, ou seja, não somente entre falantes nativos;

iii. Racismo: as proibições e restrições da convivência e relações entre os colonizadores e escravizados impostas por leis raciais impedem o contato amplo entre os grupos, favorecendo a manutenção dos aspectos citados no item anterior;

iv. O papel das mulheres escravizadas dentro do ambiente do colonizador: as mulheres podem, além de desempenhar o papel de trabalhadoras nas plantações, também trabalhar dentro da casa do colonizador, lidando com serviços domésticos, o que as deixam expostas a um grande nível de contato com a língua colonizadora, assim como serem responsáveis pela criação das crianças escravizadas e ainda dos filhos do colonizador;

v. A relação entre escravizados veteranos (ladinos) e recém-chegados (boçais): os escravizados que já se encontram trabalhando nas plantações têm a função de ensinar àqueles que chegam os métodos de produção, assim como transmitir a língua do colonizador, que pode estar em um estágio de crioulização inicial ou já estabelecida;

vi. Imposição da religião do colonizador: o ensino e o culto da religião do colonizador pode se dar por meio da língua crioula, favorecendo a transmissão dessa língua;

vii. Fugas e formação de quilombos: os escravizados fugidos das plantações se agrupam em quilombos, nos quais ficam isolados não só da sociedade como também da língua do colonizador. No entanto, esse isolamento ainda fornece alguns fatores listados anteriormente para a formação de línguas crioulas.

Os elementos descritos podiam ser encontrados na colonização atlântica durante a expansão marítima portuguesa a partir do século XV. O ambiente "ilha", por exemplo, 
poderia surgir ainda mesmo no continente, uma vez que os africanos escravizados eram levados a galpões ou fortes, nos quais ficavam confinados por longos períodos à espera dos navios negreiros. Posteriormente, os escravizados eram levados para as ilhas que serviam como entreposto, como São Tomé e Príncipe (HAGEMEIJER, 2009: 3) e, a partir dali, embarcavam para as plantações em diversos pontos da América (LORENZINO, 1996: 2).

Em São Tomé e Príncipe, encontravam-se diversos fatores que favoreceram a gênese de uma língua crioula como discorrido acima, sendo esta considerada o protocrioulo do Golfo da Guiné (cf. FERRAZ, 1979, 1987; HAGEMEIJER, 2009, 2011). Essa língua se ramificou em quatro outras línguas distintas, a saber o santome e o angolar, faladas na ilha de São Tomé, o principense ou lung'ie, falado na ilha do Príncipe, e o fa d'ambô, falado na ilha de Ano Bom (HAGEMEIJER, 2009).

Ainda que a primeira fase de ocupação tenha sido profícua para o estabelecimento das línguas autóctones nas ilhas, um segundo período da história tornou-se fundamental para o quadro linguístico de São Tomé e Príncipe (LORENZINO, 1996; HEGEMEIJER, 2009). Em meados do século XIX, o início da cultura do café e do cacau exigiu um volume enorme de mão de obra, que foi suprida com trabalhadores contratados de outros países. Assim, um grande número de trabalhadores provenientes de Cabo Verde, Angola, Moçambique e outros países africanos foram levados a São Tomé e Príncipe, ampliando o número de línguas faladas na ilha, uma vez que esses trabalhadores traziam consigo suas línguas nativas. Esses dois fatos históricos - a princípio, a produção em larga escala de cana-de-açúcar (séculos XV e XVI); e posteriormente, as produções de café e de cacau (séculos XIX e XX) - fizeram das ilhas de São Tomé e Príncipe o que Hagemeijer (2009) denominou "ilhas de Babel", ou seja, caracterizadas até os dias de hoje como um país plurilíngue. Eventos recentes (final do século XX) contribuíram ainda mais para o atual quadro linguístico do país. A partir da independência, em 1975, diversos fatores atuaram 
diretamente na sociedade e no uso das línguas, como a escolarização universal (decorrente do sistema político escolhido pós-independência), a migração dos trabalhadores das roças (fazendas) para a capital, o maior prestígio da língua portuguesa, etc. Esses e outros fatores serão detalhados na seção 1.3.4.

\subsubsection{As línguas autóctones}

São Tomé e Príncipe caracteriza-se por uma pluralidade de línguas faladas em seu território, designadamente o português, o santome, o lung'ie ou principense, o angolar, o kaboverdianu, além do português dos Tongas e resquícios de línguas africanas do grupo bantu (HAGEMEIJER, 2009). A seguir, apresentaremos algumas informações sobre essas línguas que se encontram presentes em contato com o português.

O santome, também conhecido como são-tomense, foro ou forro, é a língua autóctone mais falada no país. Foi a língua dos filhos de colonizadores portugueses com africanas escravizadas, os autodenominados "filhos de São-Tomé", que formaram o grupo étnico denominado Forro, os quais tornaram-se proprietários de terra e donos de escravos, alcançando um influente status social entre os séculos XVI-XVII (LORENZINO, 1996) e falando, originalmente, o santome. Consequentemente, a língua falada por essa sociedade, o santome, auferiu o status de língua-alvo para os novos africanos escravizados que chegavam à ilha durante o século XVI (HAGEMEIJER, 2009).

No entanto, apesar do status dessa língua durante esse período (séc. XVI-XVIII), nos dias atuais, diferente de outros países falantes de línguas crioulas, a exemplo de Cabo Verde e Curaçao, o santome não possui estatuto de língua oficial (apesar de constar na constituição como uma das línguas nacionais) e está excluído do sistema educacional. O termo "dialeto" perdura entre muitos falantes até hoje para denominar a língua santome, 
o que demonstra seu baixo prestígio na sociedade. Após a independência, em 1975, até os dias atuais, a única língua oficial e ensinada nas escolas é o português.

Outra língua falada na ilha de São Tomé é o angolar, cuja população, nos cálculos de Lorenzino (1996), é de cerca de 5000 pessoas. Os angolares são descendentes dos africanos escravizados que fugiram das roças na fase de plantação e formaram quilombos isolados na costa ao sul da ilha de São Tomé (HAGEMEIJER, 2009). O angolar, apesar de possuir o sistema sintático próximo ao santome, devido à origem comum, carrega um amplo léxico de origem bantu, especificamente do kimbundu, e ainda, em menor número, léxico edo (HAGEMEIJER, 2009). Essa especificidade do léxico na língua angolar é reflexo da própria história dessa sociedade, que viveu quase sempre marginalizada não só geograficamente, mas também do sistema econômico do país. Atualmente, residem falantes de angolar em comunidades de pescadores não mais completamente isolados, contudo distantes da capital e do centro econômico de São Tomé e Príncipe.

O lung'ie, ainda que presente no arquipélago, está restrito à ilha do Príncipe, sendo poucos os falantes residentes em São Tomé. No início do século XVI, a ilha começou a ser povoada por escravos trazidos de São Tomé, portanto falantes do protocrioulo, o que fez com que a língua se desenvolvesse de forma independente devido ao isolamento geográfico $^{6}$ e ao contato com outras línguas de novas levas de escravizados. Hagemeijer (2009) demonstra que o léxico do lung'ie apresenta características das línguas edo, enquanto fonologicamente conserva um grande número de propriedades exclusivas da área onde o edo é falado, por exemplo a presença da oclusiva velar /gb/ (FERRAZ, 1975 apud HAGEMEIJER, 2009), que inexiste nas línguas do grupo bantu; e a presença da vibrante simples [r] (HAGEMEIJER, 2009), atípica nos demais crioulos do Golfo da Guiné e no

${ }^{6} \mathrm{~A}$ Ilha do Príncipe situa-se a cerca de $150 \mathrm{~km}$ ao norte da Ilha de São Tomé. 
bantu$^{7}$. Devido ao isolamento e às outras línguas faladas no pequeno espaço geográfico da ilha do Príncipe, já se estimou erroneamente que o lung'ie se extinguisse perto dos anos 2000 (GÜNTHER, 1973). Apesar de ainda ser utilizado, o número de falantes de lung'ie é reduzido e estes possuem, em geral, mais de sessenta anos de idade e alguns poucos jovens (AGOSTINHO, em preparação). Portanto, o número cada vez menor de falantes, a falta de transmissão da língua às crianças, seu baixo prestígio e o crescente interesse em se falar o português são fatores que apontam para o desaparecimento da língua.

O kaboverdianu é uma das outras línguas crioulas faladas no país. Durante a era do café e do cacau (séc. XIX e XX), para suprir a necessidade do grande número de trabalhadores nas lavouras, foi contratada mão de obra proveniente de países da África Continental e de Cabo Verde (HAGEMEIJER, 2009). Esses contratados ficavam confinados nas roças, nas quais se encontram comunidades que ainda preservam o kabuverdianu. As características do kaboverdianu dentro do espaço geográfico de STP não foram estudadas, tampouco foram elaborados estudos comparativos entre a variedade do kaboverdianu de STP e as variedades da língua em Cabo Verde, assim como o resultado da influência desta língua no português falado em São Tomé e Príncipe.

A língua dos Tongas ou português dos Tongas também está presente no quadro linguístico dos habitantes de STP. Os Tongas são descendentes de africanos continentais que chegaram às roças, nos séculos XIX e XX. Estes aprenderam o português como L2 no ambiente de trabalho em STP (BAXTER, 2002). Muitos destes trabalhadores eram falantes de kimbundu e umbundu, originando uma língua de contato, o português dos Tongas (ROUGÉ, 1992; BAXTER, 2002, 2004; HAGEMEIJER, 2009). Essa variedade é resultado do contato das línguas dos contratados com o português falado nas roças. Ainda nos dias

${ }^{7}$ Contudo, Hagemeijer, Araujo \& Bhath (2013) argumentam que tanto o /gb/ quanto o [r] já estavam presentes no proto-crioulo. 
de hoje, de acordo com Rougé (1992: 173), os falantes das línguas dos Tongas não sabem falar santome, sendo sua língua o português como L2.

\subsubsection{A situação da línguas autóctones na sociedade são-tomense}

Em São Tomé e Príncipe, a pluralidade de línguas com baixo prestígio, frente à língua portuguesa, favoreceu o processo de desuso das línguas das comunidades marginais do sistema econômico. Situação diferente, por exemplo, à da língua kaboverdianu em Cabo Verde, que junto com as canções (mornas e coladeras) e a literatura, tornou-se parte da identidade cultural da população durante os séculos em que o país ficou, de certa forma, abandonado pela falta de interesses econômicos (CARDOSO, 2007: 150). Atualmente, o kabuverdianu goza prestígio em seu país, principalmente após a independência, quando se viu uma valorização da língua materna. Há ainda uma vontade política em constituir uma sociedade bilíngue, tornando o kaboverdianu uma língua oficial (CARDOSO, 2007).

Posicionamento inverso é visto em São Tomé e Príncipe, lugar onde o português foi e é utilizado como língua unificadora, principal meio de comunicação entre os diversos grupos, além de ser a língua presente na escolarização e a qual dá acesso ao sistema econômico. Assim, as línguas autóctones, de menor prestígio, têm seu número de falantes diminuído a cada geração e ainda são tímidas as políticas governamentais que privilegiem a valorização dos crioulos presentes no país. A valorização dessas línguas é recente e avessa ao comportamento dos falantes frente à sua língua, mesmo durante o período em que os Forros eram comunidade dominante durante o século XVII (cf. LORENZINO, 1996).

As línguas santome, lung'ie, angolar e kaboverdianu estão ainda presentes nos usos informais em São Tomé e Príncipe, como conversas de casa, entre amigos, festas populares, etc. Sendo o santome a segunda língua mais falada no país, com 33,6\% de falantes do total de habitantes (censo de 2011), é possível ouvi-lo nas conversas informais, músicas e até 
mesmo em alguns programas de rádio e televisão que visam à divulgação da cultura popular do país. Porém, o que se percebe é o crescente uso do português, que está passando de língua segunda à língua primeira no decorrer das gerações, sendo utilizado onde antes apenas os crioulos tinham espaço. Com isso, a concorrência de duas línguas no uso dos mesmos domínios, sendo que uma delas possui um status de maior prestígio (high variety ou H), ou seja, uma situação de diglossia (FERGUSON, 1964 [1959]), não possibilita aos falantes a capacidade de manter o domínio necessário à sobrevivência da língua de menor prestígio (low variety ou L), podendo promover a perda inevitável dessa língua. Sobre essa escolha pela variedade $\mathrm{H}$, refere-se Wardhaugh (1995: 09):

there may be so little prestige attached to the $\mathrm{L}$ variety that people may even deny that they know it although they may be observed to use it far more frequently than the $\mathrm{H}$ variety. Associated with this prestige valuation for the $\mathrm{H}$ variety, there is likely to be a strong feeling that the prestige is deserved because the $\mathrm{H}$ variety is more beautiful, logical, and expressive than the $\mathrm{L}$ variety. That is why it is deemed appropriate for literary use, for religious purposes, and so on. ${ }^{8}$

De fato, como atestado em diversas gravações no corpus utilizado nessa dissertação, os informantes em geral negam que dominam ou que sabem falar a língua santome, mesmo quando dizem usar a língua crioula em casa para falar com os mais velhos.

Em decorrência dessa transição e da transmissão múltipla ${ }^{9}$ do português em uma comunidade ampla de falantes, é possível que uma nova variedade esteja se estabelecendo.

\footnotetext{
8“"pode haver tão pouco prestígio associado à variedade L que as pessoas podem, até mesmo, negar que elas a conhecem, embora seja possível observá-las utilizando a variedade L muito mais que a variedade $\mathrm{H}$. Associado a essa valorização da variedade $\mathrm{H}$, é provável que exista um sentimento de que esse prestígio é merecido por se pensar que a variedade $\mathrm{H}$ é mais bonita, lógica e expressiva que a variedade L, assim ela é a apropriada para ser empregada na literatura, propósitos religiosos e assim por diante". (Tradução nossa).

"Usamos o termo "transmissão múltipla" no sentido de aprendizado de uma língua por meio de falantes que possuem diversas variedades da língua-alvo e os níveis de proficiência da L2 variam substancialmente (ARAUJO, 2011).
} 
Com o intuito de se observarem as realizações dos ditongos dessa nova variedade é que se realiza o presente trabalho.

\subsubsection{O português em São Tomé e Príncipe}

Desde a independência, em 1975, o governo de STP percebeu a importância do português como a língua de unificação dos vários grupos presentes no país (ESPÍRITO SANTO, 1985: 25), além de promover acessibilidade diante à pluralidade de línguas faladas no país, assim o português nunca perdeu o prestígio sobre as demais línguas.

Atualmente, o português é falado pela maioria da população, mais de $90 \%$ das pessoas no país (INE, 2012). Todavia, o input disponível para o português é originário de variedades interlinguísticas de português L2, fato que contribui para a formação de uma variedade distinta daquela considerada padrão. O santome, com 33,6\% de falantes (INE, 2012), é a segunda língua mais utilizada pela população. Uma vez que não foi estabelecido o controle no inquérito para o censo, não é possível definir se as línguas faladas foram adquiridas como L1 ou L2, portanto esses números apenas ilustram a situação da preponderância do uso dessas línguas no país. Todavia, Gonçalves (2010a) salienta que a aquisição do português durante a primeira fase de colonização (séc. XV), e em algumas regiões do país até recentemente, era como língua segunda (L2), uma vez que as línguas nativas (L1) - as línguas crioulas de cada região - eram adquiridas no ambiente familiar e utilizadas em situações informais. O português, língua oficial, era aprendido e praticado na sociedade apenas em situações formais, no contato com os portugueses ou estrangeiros (GONÇALVES, 2010a).

Após a independência, o português é mantido como língua oficial e, em consequência do modelo socialista adotado pelo país, se inicia a escolarização universal obrigatória. Isso faz com que se estabeleça uma norma padrão de prestígio, o português europeu, 
aprendido na escola. Na capital, por exemplo, o Liceu Nacional, no qual se encontra grande parte dos professores provenientes de Portugal, que lecionam diversas disciplinas, como filosofia, informática, matemática, língua portuguesa, etc., forma os alunos do ensino médio. Ademais, o Liceu é a única escola oficial a disponibilizar esse nível de ensino (CARDOSO, 2007: 364). Ao mesmo tempo, nos distritos mais distantes da capital, no entanto, a maioria dos professores designados para dar aulas são os alunos recém-formados no ensino médio, os quais não dominam a "norma culta lusitana"10. Dessa maneira, o aprendizado da variedade de prestígio nos distritos periféricos é precário, não só pela baixa qualidade do ensino, como também pela falta de uma especialização e preparo profissional para a formação de professores. Os estudos dos reflexos desse sistema de ensino (com professores que buscam ensinar a "norma culta" do português sem a dominar) e sobre como o contato das línguas crioulas com o português pode influenciar uma à outra ainda são poucos; no entanto, Gonçalves (2010a), em sua dissertação de mestrado, por exemplo, demonstrou como o santome pode estar influenciando a sintaxe do PVS, ao que se refere à substituição da preposição "a" por "até". Em (1) e (2) estão dois exemplos de construções com o verbo "ir" em santome (exemplos de HAGEMEIJER, 2009).

(1) $\hat{\mathbf{E}}$ ba ke.

3SG ir casa

'Ele foi a/para casa.'

(2) A ka be ku non antê poson. IMP ASP ir com 1PL até cidade 'Vão conosco à cidade.'

10 No período entre janeiro e fevereiro de 2011, com Gabriela Braga, a prof. Joana Castaño do Instituto Superior Politécnico (ISP) e o prof. Paulo Rodrigues do Liceu Nacional, fizemos um trabalho em conjunto analisando a produção escrita de alunos do último ano do ensino médio do Liceu Nacional, constatando grande número de "desvios" e falta de domínio da norma padrão escrita. Os resultados foram apresentados no Centro Cultural como parte dos eventos do Dia da Língua Nacional e atividade pelo convênio entre a Universidade de São Paulo e o Instituto Nacional Politécnico. 
Em (3), vemos a construção de uma frase com o verbo ir em PVS e como ela é construída em PE (exemplo de GONÇALVES, 2010a):

(3) Já fui até Pico também quando era mais miúdo.

$(\mathrm{PE}=$ fui ao Pico $)$

Em síntese, observamos que o Pvs se encontra em um contexto no qual há uma situação de contato com outras línguas, sofrendo influências que modificam essa variedade de português, dando-lhe características distintas da variedade de maior prestígio, o PE (cf. FIGUEIREDO, 2008, 2009, 2010; HAGEMEIJER, 2009; GONÇALVES, 2010, CHRISTOFOLETTI, 2011; SANTOS \& CHRISTOFOLETTI, 2011).

\subsection{Métodos de coleta e classificação do corpus}

O corpus utilizado no presente trabalho foi constituído por dados coletados durante minha Iniciação Científica entre 2009 e 2010 (CHRISTOFOLETTI, 2010) e é composto por arquivos de áudio em formato WAV (cada informante possui um arquivo específico) e trinta minutos transcritos de cada informante. As gravações são de fala espontânea e foram feitas em diversos ambientes com um gravador digital. Antes de se iniciar a gravação, foram coletadas algumas informações sociolinguísticas dos informantes, como a naturalidade (foi dada preferência a informantes oriundos da cidade de São Tomé), filiação (pais sãotomenses $)^{11}$, informações sobre escolaridade, além de solicitar a permissão do falante para documentação e informá-lo sobre a natureza da pesquisa ${ }^{12}$. Em seguida, o entrevistador dava início à conversa que tratava de temas gerais, tentando amenizar a presença do gravador, que age sempre como inibidor em situações de fala espontânea (VAUX, COOPER

\footnotetext{
11 Pai e mãe nascidos em STP e não provenientes de outros países, como, por exemplo, Cabo Verde. ${ }^{12}$ Tomamos o cuidado de apenas informar que se tratava de uma pesquisa universitária, sem apresentar o tema que estava sendo pesquisado.
} 
\& TUCKER, 2007). Labov (1991 [1972]) demonstra que as narrativas pessoais são as mais produtivas para a conversação espontânea, pois, ao narrar suas próprias experiências de vida, o falante se desliga da forma como verbaliza. Partindo dessa observação, Lucchesi, Baxter \& Ribeiro (2009: 160-162) apontam alguns tópicos que se revelaram propícios para estimular o informante, deixando-o mais à vontade e aliviando o controle de fala. Nas entrevistas, utilizaram-se com frequência temas como a descrição de festas populares locais, a história da comunidade, a emigração, as festas religiosas, os casamentos, os aspectos da vida conjugal, etc., além de desenvolver alguns temas próprios que se mostraram produtivos, como a situação econômica do país, os casos de corrupção na política e as futuras eleições.

Durante a coleta das gravações, os falantes foram escolhidos de forma aleatória. Posteriormente, para respeitar o método de análise variacionista e pensando na utilidade desses dados em um estudo sobre variação e processos fonológicos, os falantes foram separados considerando as seguintes variáveis:

a) Sexo: masculino, feminino. Esta distinção é necessária para apontar em qual dos dois gêneros a variação fica mais evidente, uma vez que as variações linguísticas podem se manifestar de formas distintas conforme o gênero do falante.

b) Idade: faixa 1 (quinze a vinte e cinco anos), faixa 2 (vinte e seis a quarenta anos) e faixa 3 (mais de quarenta anos ${ }^{13}$ ). Assim, teremos três grupos bem distintos, formados por pessoas que nasceram antes da independência, no período comunista (1975-1990) e no período capitalista (pós 1990). As três faixas etárias para análise foram escolhidas levando em consideração o número de anos (quinze) utilizado para definir uma geração (cf. NARO, 2003: 44). A escolha da idade inicial parte da hipótese clássica da abordagem em tempo

${ }^{13} \mathrm{O}$ informante mais idoso tinha a idade de 53 anos 
aparente, na qual "o estado atual da língua de um falante adulto reflete o estado da língua adquirida quando o falante tinha aproximadamente 15 anos de idade" (NARO, 2003: 44).

c) Escolaridade: baixa, média e alta. Baixa - menos de três anos; média - de três a nove anos; alta - mais de nove anos. É a partir dela que, ao cruzar os dados, poder-se-á observar se a variação da realização dos ditongos está ligada ao tempo de escolaridade e quantificar a influência da escola na realização dos ditongos no português vernacular sãotomense. Nas amostras, apesar de não haver informantes com zero ano de escolaridade, a maior parte dos informantes com até três anos de escolaridade não conseguia ler e alguns, mesmo com cinco anos de escolaridade, mostraram-se com muita dificuldade de leitura, quando conseguiam.

Com o cruzamento das categorias sociais: idade, escolaridade e sexo, formou-se um conjunto com dezoito perfis distintos, porém, quatro desses perfis (aqueles cuja escolaridade era de nível mais baixo) não estavam disponíveis para a gravação. Desse modo, em um segundo trabalho de campo, ocorrido no início de 2011, com a duração de dois meses, o conjunto de informantes foi completado. Além disso, foi possível gravar mais material de fala espontânea, totalizando 50 horas de gravação. Paralelo à busca pelos perfis, criamos também um corpus à parte com coletas de fala controlada, no qual pedimos ao informante que falasse uma lista de palavras-alvo (contendo ditongos) dentro de uma frase-veículo ("Eu digo _____ bem alto"), que foi repetida para melhor captação do áudio. Esse material não foi usado nas análises estatísticas presentes neste trabalho. O objetivo principal foi utilizar apenas o corpus de fala espontânea para a verificação da realização dos ditongos no PVS, no entanto o corpus paralelo serviu para analisar a estrutura de ditongos que não apareceram ou apareceram raramente na fala espontânea.

Foram escolhidos os falantes que, além de se encaixarem no perfil (falantes de português nascidos em STP e filhos de pais são-tomenses), fizeram as entrevistas com mais dados 
aproveitáveis e com melhor qualidade de áudio. Na Figura 1.4, apresentamos um diagrama de como ficaram organizados os perfis. Na primeira linha, estão divididos os grupos em Masculino/Feminino; na segunda linha, se encontra a divisão por faixa etária (faixa 1: 15-25, faixa 2: 26-45 e faixa 3: mais de 45); na terceira linha, o nível referente aos anos de escolaridade (baixo: até 3 anos, médio: de 3 a 9 anos e alto: mais de 9 anos); e na última linha, encontram-se as iniciais dos falantes que se encaixaram no seu respectivo perfil:

\begin{tabular}{|c|c|c|c|c|c|c|c|c|c|c|c|c|c|c|c|c|c|}
\hline sexo & & & $\mathrm{Ma}$ & $\mathrm{SC}$ & ino & & & & & & & & ni & & & & \\
\hline idade & Faix & & & aixa & & & aixa & & & aixa & & & ixa & & & ixa & \\
\hline ridade & \begin{tabular}{|l|l} 
Alta & Medi
\end{tabular} & Baixa & Atta & Media & Baixa & Alta & Media & Baixa & Alta & Media & Baixa & Atra & Media & Baixa & Ata & Media & Baixa \\
\hline nante & \begin{tabular}{|l|l} 
AP & LEE
\end{tabular} & LEL & GIC & CAS & Jos & VAS & ASN & AA & ASS & $\mathrm{NFC}$ & LAU & INC & $\mathrm{NC}$ & ALC & MAR & ANA & IG \\
\hline
\end{tabular}

Figura 1.4: Diagrama de falantes classificados de acordo com as variáveis sociais.

No corpus, estão inseridos e classificados dados de todas as ocorrências das palavras com ditongo documentadas durante as 18 entrevistas (seguindo o método apresentado na seção 1.4). Assim, se a palavra "motoqueiro", por exemplo, foi repetida três vezes por um falante, ela foi inserida e analisada todas as três vezes de modo independente. Esse método visa registrar todas as possíveis realizações das palavras, pois uma mesma pessoa pode pronunciar uma mesma palavra de forma diferente, assim, temos condições de abranger o máximo possível de realizações e até, por meio das análises estatísticas, verificar as suas ocorrências. Por outro lado, pronúncias idiossincráticas poderiam interferir nos números, daí a necessidade de se utilizar diversos falantes, com todas as combinações das variáveis sociais elencadas possíveis. Essas informações serviram como base para se chegar aos resultados finais, uma vez que todas as ocorrências das palavras com ditongo foram recolhidas e classificadas.

Os ditongos orais formados pelo processo de ditongação nas sílabas fechadas com coda /S/, como em "três" ['treIf]], "mês" ['meIJ]] e "mas" ['maIj]], foram excluídos nesta análise, 
uma vez que, nesses contextos, a formação do ditongo é opcional e se dá no nível fonético por espraiamento do traço [+coronal] da consoante seguinte (cf. BISOL, 2009). Todavia, é importante salientar que esse processo de espraiamento e formação de ditongo, o qual Cintra (1983) aponta ser uma diferença entre as variedades de português faladas no Brasil, nas quais o processo ocorre, e as faladas em Portugal, acontece também no PVs. Em Cintra (1983), não foram levantados quantitativamente os dados, mas exemplos do processo de ditongação são frequentes nos falantes do PVS, principalmente quando a vogal nuclear é /e/, seguida de /s/. No trabalho de Leiria (1995), a autora observa que, nas variedades do sul do Brasil, a ditongação de sílabas travadas em /S/ e cuja vogal nuclear é /e/ é substancialmente mais comum. Dessa forma, um trabalho voltado a esse caso específico no PVS pode ser um tema de uma pesquisa futura.

Para o trabalho com os dados do corpus, foi organizado um quadro, no qual foram inseridas as palavras contendo o ditongo no espaço correspondente às linhas e, então, classificadas conforme as variáveis linguísticas e extralinguísticas a serem elencadas nessa seção, situadas nos espaços de dezesseis colunas. Na primeira coluna, foi inserido o registro gráfico da palavra, selecionada no corpus gravado em áudio. Em seguida, na segunda coluna, foi feita a transcrição fonética da palavra, usando-se o alfabeto fonético internacional. Na terceira coluna, foi anotada a marcação do tempo, presente no arquivo de áudio, em que a palavra ocorre. Como algumas entrevistas estão divididas em diversos arquivos, foi criada uma quarta coluna, na qual é identificado o número desse arquivo. Na quinta coluna, foi identificada a vogal núcleo por meio de um código único para cada possibilidade de realização. Na sexta coluna, foi inserido o tipo do glide que constitui o ditongo, "j” para 
o anterior, "w" para o glide posterior ${ }^{14}$. Na sétima coluna, foi identificado o contexto seguinte $^{15}$ ao ditongo, ou seja, qual fonema ocorre imediatamente após o ditongo. Na oitava coluna, foi inserida a classe das palavras, divididas em verbos (v) e não-verbos (n), uma vez que alguns processos fonológicos ocorrem de forma distinta em cada categoria. Na nona coluna, encontra-se identificado o posicionamento do ditongo na palavra, se no início (1), meio (2) ou fim (3). Na décima coluna, foi classificado o acento do ditongo, se pretônico (p), tônico (t) ou postônico (o). Visando observar se há influência da morfologia na realização dos ditongos, na décima primeira coluna foi identificada a localização morfológica, ou seja, se o ditongo se encontra na base (b) ou no afixo (a) da palavra. A décima segunda coluna pertence à variável dependente, na qual foi identificado se houve (1), ou não (0), o processo de monotongação. Nas quatro últimas colunas estão registrados os dados sobre idade (1, 2 e 3), escolaridade (b (baixa), c (média) e d (alta)), sexo (m, f) e iniciais do informante, respectivamente.

\subsubsection{Variável linguística dependente}

O foco desse trabalho será investigar as realizações dos ditongos orais decrescentes, os quais podem ser realizados plenamente ou de forma monotongada. Assim, a variável dependente neste estudo será a aplicação, ou não, do processo de monotongação no ditongo alvo. Dessa forma, foi organizada uma tabela única para cada possibilidade de ocorrência de ditongo

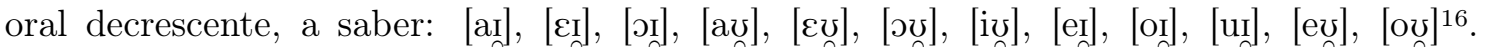
Algumas possibilidades foram descartadas por falta de ocorrência, como [əI] e [ov] , nesse

\footnotetext{
${ }^{14}$ Os valores escolhidos para representar as variáveis na tabela são apenas para referência rotular no uso do programa Goldvarb 2001, podendo ser expressa por qualquer caractere alfanumérico. Dessa forma, a escolha por "j" e "w" não tem relação com a característica linguística do glide, que será discutida no capítulo 2.

${ }^{15}$ Foi observado apenas o contexto seguinte por causa de sua influência nos segmentos precedentes verificados em outros estudos sobre monotongação como Meneghini (1983), Paiva (1996), Cabreira (1996) e Mollica (1998).

${ }^{16}$ A notação dos ditongos é seguida conforme transcrição fonética proposta por Silva (2010).
} 
caso, recorremos aos dados do corpus de fala controlada para observar a realização fonética do ditongo, porém sem juntar aos dados que receberam tratamento estatístico. Assim, a análise desses dados não foi feita por meio de estatísticas calculadas pelo Goldvarb 2001, mas apenas observadas as possibilidades de realizações em variados perfis de falantes.

\subsubsection{Variáveis linguísticas independentes}

As variáveis linguísticas independentes são aquelas que podem vir a influenciar no resultado da variável dependente. Assim, as variáveis aplicadas escolhidas, neste estudo, foram:

a) Classe morfológica do item lexical: Permite observar se os processos de monotongação ou manutenção do ditongo estariam condicionados à classe morfológica da palavra em que se encontra o ditongo. São examinadas as seguintes possibilidades: verbos e nãoverbos.

b) Posição do ditongo no vocábulo: Refere-se à localização do ditongo dentro da palavra. São consideradas três possibilidades: posição inicial, posição medial e posição final. Nos casos de monossílabos, serão considerados como em posição inicial. Essa escolha se baseou no fato de os monossílabos, por serem tônicos, se aproximarem mais de uma sílaba no início do que uma sílaba no fim de palavra. Em dissílabos, a segunda sílaba será considerada final. Nas palavras com três ou mais sílabas, excetuando a primeira e a última sílaba, todas entre essas são consideradas mediais.

c) Tonicidade: O controle dessa variável busca averiguar se a aplicação da regra de monotongação ou a manutenção do ditongo sofre influências do acento na sílaba em que ocorre ou ocorreria o ditongo. As palavras serão separadas em quatro grupos de acordo com o tipo de sílaba na qual o ditongo está presente: tônica, pretônica, postônica ou átona final.

d) Localização do ditongo na estrutura morfológica da palavra: Esta variável diz respeito 
ao tipo de morfema em que ocorre o ditongo. São consideradas duas possibilidades: o locus do ditongo encontra-se na raiz da palavra ou no afixo (prefixos ou sufixos).

e) Contexto fonético subsequente: Refere-se à natureza do elemento imediatamente adjacente após o ditongo. Por meio dessa informação, serão observados quais segmentos influenciam a aplicação ou não da regra de monotongação. Serão considerados o ponto e o modo de articulação das consoantes: bilabiais (p, b), labiodentais (f, v), alveolares plosivas $(\mathrm{t}, \mathrm{d})$, alveolares fricativas $(\mathrm{s}, \mathrm{z})$, pós-alveolares $\left(\int, 3\right)$, velares $(\mathrm{k}, \mathrm{g})$, nasais $(\mathrm{n}, \mathrm{m})$, róticos $(\mathrm{r}, \mathrm{r}$, в), vogais e de pausa (fim de palavra).

f) Número de sílabas da palavra: Foi controlado ainda o tamanho da palavra, contandose seu número de sílabas. Dividimos as palavras em uma (1), duas (2), três (3) ou mais sílabas (4). Dessa forma, poderíamos observar se essa variável influenciaria na aplicação do processo de monotongação.

As variáveis independentes sociais são as mesmas citadas anteriormente, ou seja: idade, escolaridade e sexo. A variável idade foi dividida em três faixas etárias e a variável escolaridade em três grupos de tempo de permanência na escola. A variável sexo foi composta pela divisão masculino e feminino.

A princípio, optou-se por inserir na tabela todas as palavras que continham ditongos pronunciadas pelo falante durante a entrevista. No entanto, como o tempo das entrevistas varia de trinta minutos a duas horas, foi adaptado e aplicado o método desenvolvido por Pagotto (2004), buscando balancear os dados. O método consiste em iniciar a coleta a partir dos dez primeiros minutos da gravação (o que também evitou coletar dados de fala controlada, enquanto o falante ainda se encontra inibido pela gravação) e limitar a coleta até os 40 minutos da entrevista. Esse processo busca:

(...) evitar que se extraíssem exaustivamente todas as ocorrências da variável numa única entrevista, o que, além de sobrecarregar o trabalho de computação, 
poderia implicar o desbalanceamento excessivo dos dados (PAGOTTO, 2004: 244).

Como definição de "palavra", para a documentação dos ditongos no corpus, utilizamos a proposta de Vigário $(2003,2007)$ para a palavra prosódica mínima. Assim, não utilizamos o termo palavra no que concerne à morfologia ou à ortografia. Toneli (2011: 2) define a palavra prosódica mínima da seguinte forma:

a palavra é dotada apenas de um acento primário e é formada por estruturas incorporadas (palavras com sufixos ou hospedeiros mais enclíticos), como em "hospede+aria" = hospedaria [ospeda'ria]; fala + se = fala-se ['falasi], ou estruturas adjungidas (palavras com prefixos ou hospedeiros mais proclíticos) como em re + escrita $=$ reescrita $[$ rescrita], $\mathrm{me}+$ fala $=$ me fala $[$ mi'fala].

No apêndice desse texto, há um exemplo da tabela com os dados inseridos, na qual é possível visualizar a organização do material. Esse tipo de organização, por meio de tabelas no software Microsoft Excel, mostrou-se ideal para a recuperação de informações por meio dos filtros automáticos, além de possibilitar a criação de lista em arquivos .txt para alimentar as análises estatísticas.

\subsection{Prolegômenos ao uso dos dados estatísticos}

\section{variacionistas}

Para obtermos evidências para as análises apresentadas nesta dissertação, foi preciso, além do levantamento do corpus e seleção das variáveis apresentadas na seção 1.4, dispor de uma ferramenta que fosse capaz de calcular as estatísticas necessárias utilizando a grande quantidade de dados obtidos. Dessa forma, escolhemos o software Goldvarb 2001 (ROBINSON, LAWRENCE \& TAGLIAMONTE, 2001) para análise multivariada. Essa versão para plataforma Windows é baseada no programa anterior Goldvarb 2.0 (RAND \& SANKOFF, 
1990), que fora desenvolvido para computadores Macintosh. O Goldvarb é uma versão do pacote Varbrul (Variable Rules Analysis), "um conjunto de programas computacionais de análise multivariada, especificamente estruturado para acomodar dados de variação sociolinguística" (GUY \& ZILLES, 2007: 105).

A análise multivariada proporciona resultados que nos guiam na busca de explicações para os fenômenos linguísticos observados. Isso significa que os números aqui apresentados servem como evidências que darão suporte a uma hipótese, e não que os números em si sejam respostas absolutas. Neste trabalho, aparecerão, com frequência, referências a duas categorias de resultados importantes obtidos por meio do Goldvarb 2001, por esse motivo, explicarei a seguir o significado desses números.

O primeiro se refere ao peso relativo, o valor de cada fator da análise que é "a estimativa dos efeitos restritivos e sua significância" (GUY \& ZILLES, 2007: 41). Esse valor será um número entre 0 e 1 , o qual indica a direção e a intensidade que uma das variáveis influencia na regra (no caso de nosso estudo, a monotongação). Existe um padrão para a interpretação desses valores: valores acima de 0,5 indicam um favorecimento à aplicação da regra; valores abaixo de 0,5 indicam um desfavorecimento; e valores iguais a 0,5 indicam que a variável em questão não influencia na aplicação da regra. Além disso, é possível haver os knockouts, ou seja, valores iguais a 0 que indicam que a regra nunca se aplica naquela variável, assim como valores iguais a 1, que indicarão que a regra sempre será aplicada no contexto da variável em questão.

O segundo valor ao qual faremos referências neste trabalho tem relação com o número de significância do conjunto de variáveis escolhidas pelo Goldvarb 2001. Após aplicar a função Step Up EJ Down no programa, este gera uma lista com as estatísticas testadas dos pesos relativos e todas as variáveis, e retorna então a qualidade do conjunto de variáveis que tem maior probabilidade de estar influenciando no fenômeno linguístico que estamos 
analisando. O valor indicado pelo programa representa a significância da variável para a variação pesquisada, nesse caso, a monotongação. O valor, quanto mais próximo de 0 , representa uma maior significância.

Durante o processo, pode acontecer de algumas variáveis retornarem resultados categóricos, conhecidos como knockouts. Quando isso ocorre, faz-se necessário analisar cada caso para que possamos decidir qual a melhor decisão a ser tomada, como juntar variáveis ou descartá-las e recodificá-las para uma nova rodada. Neste trabalho, quando esta situação ocorrer, detalharemos os procedimentos tomados. 


\section{Capítulo 2}

\section{Os ditongos}

Neste capítulo, apresentaremos uma síntese da bibliografia consultada sobre os ditongos na língua portuguesa, tanto na variedade europeia, considerada a norma padrão em STP, quanto na variedade brasileira. A justificativa para se observarem estudos do ditongo no PB baseia-se nas características do sistema vocálico do PVS que, segundo Christofoletti (2010), se aproxima dessa variedade. Assim, a seguir, partiremos das observações acerca do sistema vocálico do PVS e, posteriormente, discorreremos sobre os estudos dos ditongos nas variedades do português.

\subsection{Alguns aspectos da fonologia das línguas nacionais de STP}

Por meio da observação dos exemplos de palavras de origem portuguesa nos crioulos do Golfo da Guiné, conseguimos elencar alguns processos fonológicos aplicados na adaptação do léxico português. Esses processos fonológicos formam um padrão que é encontrado em todos os crioulos de base portuguesa do Golfo da Guiné, o que contribui para a hipótese da origem comum desses crioulos. Todavia, esses processos foram ainda observados no kaboverdianu, um crioulo da Alta Guiné, fato que permite considerar a hipótese de que forças sociolinguísticas semelhantes atuam nessas línguas. A seguir, por terem relação 
direta com os ditongos, as características da fonologia das línguas santome, principense e angolar que serão apresentadas são: restrição à coda; monotongação; e metátese.

\subsubsection{Restrição à coda}

Uma das restrições de marcação mais profícuas nas línguas, a qual tende a evitar a construção de sílabas pesadas, ou seja, preencher o elemento da posição de coda, tem relação direta com a realização dos ditongos, uma vez que consideramos o glide do ditongo decrescente na posição da coda silábica. No santome, existe uma restrição ao preenchimento da coda, sendo que o único elemento realizado nessa posição é o [f] (como em [dif'glasa], ['flefku], ['kaJka]) (ARAUJO, 2010). Ainda assim, sua distribuição é restrita à sílaba inicial (posição mais comum) ou medial (posição menos comum) da palavra, não ocorrendo em posição de fim de palavra (ARAUJO, 2010). Dessa forma, as palavras que em português possuíam alguma líquida na coda (/l, R/) sofreram processos fonológicos como metátese (4a), paragoge (4b), epêntese (4c) ou simples apagamento (4d). Exemplos de Araujo (2010):

(4) a. fal.cão [fla.'kõ]

b. flor ['flo.li]

c. ór.fão ['o.lu.fu]

d. tar.ta.ru.ga [ta.ta.'lu.ga]

O mesmo padrão é observado no angolar que, assim como visto no santome, restringe o preenchimento da coda, sendo que nem mesmo o fonema /S/ é utilizado. Maurer (1995: 35) considera que "L'Agolar ne connaît pas de syllabes fermées, à l'exception des syllabes fermées par une consonne nasale, comme dans an-da 'mâcher'"17. Nos exemplos, de

\footnotetext{
17"O angolar desconhece sílabas fechadas, exceto as sílabas fechadas por uma consoante nasal,
} como em an-da 'andar'" (tradução nossa). 
Graham \& Graham (2004), podemos observar os processos de metátese (5a), apagamento (5b) e epêntese (5c):

(5) a. na.riz ['di.si]

b. tar.ta.ru.ga [te.te.'u.g $\left.{ }^{\mathrm{w}} \mathrm{a}\right]$

c. sal ['sa.lu]

Em decorrência da restrição à formação de coda, ocorrem processos como o apagamento (6a), a paragoge (6b) e a metátese (6c). Estes processos, que também ocorrem no santome, aqui são aplicados de forma distinta, uma vez que o onset complexo em angolar é proibido (MAURER, 1995: 34), diferente do santome. Uma dessas formas distintas é o alongamento da vogal do núcleo para suprir o apagamento da coda (6d):

(6) a. fes.ta ['fe.sa]

b. sal ['sa.lu]

c. es.co.la [si.'ko.la]

d. mul.tar [mus.'ta]

O principense apresenta alguns traços semelhantes aos demonstrados anteriormente nas outras línguas crioulas, como a restrição ao preenchimento de coda e, assim como nas outras línguas crioulas, são utilizados alguns processos para a adaptação das palavras. Em (7a) e (7b) é utilizado o apagamento da coda, em (7c), ocorre a epêntese, transformando a coda em onset e formando uma nova sílaba:

(7) a. por.to ['po.tu]

b. mor.te ['mo.tji]

c. cal.ção [ka.li.'sã] 
Na coda, podem ocorrer apenas traços nasais $(8 \mathrm{a}, 8 \mathrm{~b})$ ou glides (8c, 8d) (AGOSTINHO, em preparação), exemplos da autora:

(8) a. pron.to ['prõ.tu]

b. trin.ta ['trĩ.ta]

c. ba.rro [u.'bav $]$

d. fe.rro [u.'fev]

\subsubsection{Processos fonológicos das palavras com ditongos}

Apesar de o processo de monotongação na realização de ditongos já ser verificado no português arcaico (TEYSSIER, 2001 [1989]; SILVA, 2006), ou seja, os ditongos já se encontravam em variação, podemos afirmar que as palavras com ditongos do português que serviram como léxico para os crioulos não estavam com o processo de monotongação estabelecido. Assim, devido a razões estruturais, as línguas crioulas não incluíram os ditongos na aquisição de seu léxico.

Os únicos ditongos existentes em santome são os crescentes. Nos exemplos abaixo, retirados de Araujo (2010), as palavras de origem portuguesa que possuíam ditongos decrescentes são realizadas sem o ditongo no santome, como visto em (9), mesmo nas palavras que possuem os ditongos considerados "verdadeiros", como em (9d, 9e, 9f). Em (9a e 9b), observamos a monotongação dos ditongos em contextos atestados em português até os dias atuais, ou seja, diante de /r/, em (9c), vemos outra monotongação presente amplamente aplicada em diversas variedades de português. Contudo, em (9d), (9e) e (9f), temos exemplos de monotongações que não são comuns nas variedades de português, tanto brasileiro, quanto europeu, ou seja, diante de /t/ ou /d/, porém, documentadas na variedade estudada neste trabalho, o PVS, ao menos no que concerne ao ditongo [eI]. 
(9) a. ban.dei.ra [bẽ.'de.la]

b. po.ei.ra [pu.'c.la]

c. ou.tro ['o.tlu]

d. noi.te ['not $\left.\int \mathrm{I}\right]$

e. lei.te ['lete]

f. doi.do ['dodo]

Em (10), vemos um exemplo do processo que transformou um ditongo decrescente em um crescente, isto é [oI] $\rightarrow[$ [

(10) boi ['bune]

Podemos relacionar o processo em (10) com os ditongos pela restrição do preenchimento da coda, que pode estar bloqueando a inserção do glide, inibindo a formação do ditongo na sílaba. Essa restrição corrobora a proposta de Collischonn (1997), a qual aponta o glide como constituinte de coda e não como parte do núcleo, contrariando, portanto, a proposta de Mateus \& D'Andrade (2000), vista em 2.1.2, a qual analisava o glide como parte do núcleo da sílaba.

O angolar também não possui ditongos decrescentes em seu sistema fonológico. As palavras apresentam as mesmas características explicadas acima nos exemplos do santome. Nos dados do angolar (11 e 12), ocorreu a monotongação mesmo que o ditongo estivesse em posição tônica, como em (11a), no qual há também um abaixamento da vogal; ou ainda em posição átona, como em (11b) e (11c). Existem ainda exemplos do processo de adaptação de ditongos decrescentes em crescentes (12), devido à restrição do preenchimento da coda. Abaixo estão listados alguns exemplos retirados de Graham \& Graham (2004): 
(11) a. lei.te ['le.te]

b. chei.rar [se.'la]

c. quei.mar [ke.'ma]

(12) boi ['bue]

Os mesmos casos de monotongação ou metátese de palavras com ditongos no português podem ser observados no principense, porém há uma singularidade nessa língua que está no fato de que, apesar da sequência GV ser mais comum, como visto em todos os ditongos em (13), é possível encontrar palavras com a sequência VG (14). Podemos observar que, em (14a), a palavra de origem portuguesa ganhou uma vogal temática inicial e, ao apagar o fonema /r/, formou-se o ditongo VG tônico, em (14b), o ditongo pretônico foi totalmente elidido, sendo preservado o ditongo VG tônico (exemplos de Agostinho, em preparação).

(13) a. boi ['bune]

b. pai ['pvָe]

c. di.nhei.ro ['dino]

(14) a. fe.rro [u.'feṽ]

b. eu.ro.peu [ro.'pev]

O kaboverdianu, um crioulo da Alta Guiné, mas falado também em STP, permite o preenchimento da coda com os fonemas $/ \mathrm{R} /$, /S/, /N/ e /l/. Porém, como mostrado nos exemplos em (15) (ROUGÉ, 2004), é possível encontrar processos de monotongação que são atestados nos dados do PVS, como os exemplos a seguir do kaburdianu (variante de Santiago): 
(15) a. di.rei.tos [di.'re.tus]

b. pei.to ['pe.tu]

c. com.pa.nhei.ro [kũ.pa.'ne.ru]

\subsection{O sistema vocálico do PVS}

Christofoletti (2010) constatou que o sistema vocálico do PVS se distancia do sistema vocálico do $\mathrm{PE}$, apresentando algumas características próprias. No quadro das vogais tônicas orais do PE, norma considerada de prestígio em STP, figuram nove sons vocálicos (fones) distintos: [u, i, $\varepsilon, \mathrm{e}$, , , o, a, e, ə] (RUA, 2005: 37), enquanto que, no PVs, foi observada a ausência categórica de vogais médias-centrais [ə] e [๔] (entre as vogais tônicas), formando um quadro de sete vogais orais $[\mathrm{u}, \mathrm{i}, \varepsilon, \mathrm{e}, \mathrm{\jmath}, \mathrm{o}, \mathrm{a}]^{18}$. A seguir, discorreremos sobre os elementos vocálicos em cada posição acentual da palavra.

A sílaba tônica é aquela que recebe maior elevação de voz (tom) e intensidade em uma palavra na língua portuguesa, conforme Câmara Jr. (1995 [1970]), sendo esta a posição ideal para se identificar as vogais, por ela dispor, em sua plenitude e nitidez, os traços que as distinguem. Ao se referir às vogais em sílaba tônica em variedades do português, a principal diferença notada entre o PE (de Lisboa, cf. MATEUS \& D'ANDRADE, 2000) e a variedade brasileira (falar culto do Rio de Janeiro, descrito por CÂMARA JR., 1995 [1970]) é a presença da vogal média-central [ə] e da vogal [e] na variedade europeia. Quando a vogal tônica, no nível subjacente, for a média-alta anterior /e/, segundo Mateus \& D'Andrade (2000), será realizada como [ə] se for seguida de consoante palatal ou glide anterior, por exemplo, nas palavras do PE (variedade de Lisboa): "lei" ['ləI], "abelha" [a'bəイe], "fecho"

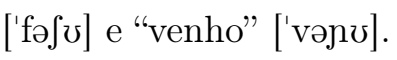

${ }^{18} \mathrm{O}$ segmento vocálico [e] também se encontra no PVS como um alofone de [a], sendo realizado conforme o contexto em que se encontra. 
Nos dados do PVS, não foi encontrada ocorrência da vogal média-central [ə], mesmo nos contextos em que, no PE descrito por Mateus \& D'Andrade (2000), deveria ocorrer, como diante de consoante palatal, conforme o exemplo retirado do PVs "igreja" [i'greze] ou de um glide anterior, como em "ligeiro" [li'zerv]. No caso dos verbos, os quais, segundo Câmara Jr. (1995 [1970]) seriam os exemplos clássicos para os que defendem dois fonemas /a/ distintos ${ }^{19}$, quando conjugados no pretérito perfeito e no presente, como nos exem-

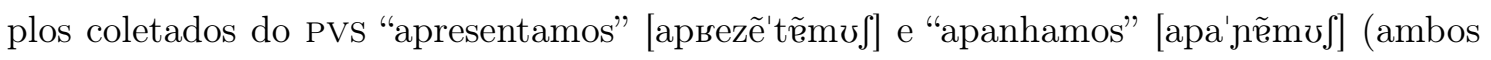
no pretérito perfeito), vê-se que a vogal da sílaba tônica foi nasalizada por estar contígua a uma consoante nasal (regra obrigatória no PB, porém não no $\mathrm{PE}$ ) e, portanto, não foi considerada como uma realização do schwa [ə], mas como uma vogal [a], levemente centra-

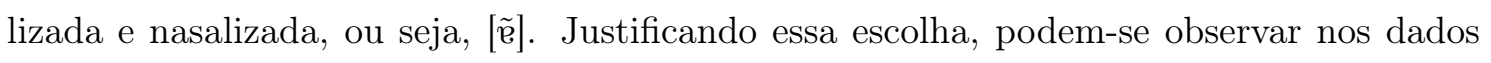
algumas realizações da vogal baixa tônica não nasalizada diante de consoante nasal, como

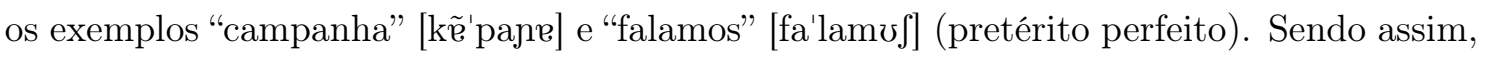
observamos que o subsistema vocálico tônico do PVS é composto por sete vogais orais, $/ \mathrm{u}$, i, $\varepsilon$, e, ə, o, a/, sem a presença do schwa [ə], mesmo como alofone do [e] tônico. No Quadro 1, estão demonstradas as palavras, retiradas do corpus, contendo cada uma das vogais tônicas orais em palavras com diferentes números de sílabas:

\footnotetext{
19"O exemplo clássico é a oposição, na $1^{\mathrm{a}}$ conjugação verbal, entre -ámos (terminação no pretérito perfeito: "ontem cantámos") e -amos (terminação no presente: "cantamos agora e sempre"). Tal oposição parece muito frequente, por causa do grande número de verbos da $1^{\mathrm{a}}$ conjugação; mas em última análise não o é, pois só depende de duas terminações únicas." (CÂMARA JR. 1995 [1970]: 41).
} 


\begin{tabular}{|c|c|c|c|c|c|c|c|c|}
\hline \multirow[b]{2}{*}[\mathrm{i}]{} & \multicolumn{2}{|c|}{ Monossílaba } & \multicolumn{2}{|c|}{ Dissílaba } & \multicolumn{2}{|c|}{ Trissílaba } & \multicolumn{2}{|c|}{ Polissílaba } \\
\hline & mil & ['mił] & vida & ['vide] & feitiço & [fe'tisv] & cansativo & [kãsa'tivv] \\
\hline [u] & luz & ['luf] & cura & ['kuьs] & noturno & [no'turnv] & guadalupe & [gwada'lupi] \\
\hline [e] & três & ['tref] & chego & ['/egv] & empresa & [ẽ'preze] & eza & [natu'reze] \\
\hline$[\varepsilon]$ & dez & ['d $\left.\varepsilon \int\right]$ & hotel & [o'tet] & novela & [no'vele] & discoteca & [difkv'teke] \\
\hline [o] & dois & ['dof] & calor & [ka'lo] & agosto & [a'goftu] & perigoso & [peri'gozv] \\
\hline$[\ni]$ & nós & ['nつf] & avó & [a'vo] & angola & [ã'gole] & camisola & [kami'zole] \\
\hline [a] & sal & ['sał] & fraca & ['frake] & cidade & [si'dadi] & amizade & [ami'zadi] \\
\hline
\end{tabular}

Quadro 1: Quadro de exemplos de vogais tônicas.

As vogais tônicas apresentadas no Quadro 1 são as mesmas encontradas na variedade brasileira, ou seja, sete vogais orais na posição tônica: /i, u, e, o, ع, ə, a/. As línguas crioulas locais e em contato direto com a variedade do português falado ali possuem, também, um sistema vocálico constituído pelo conjunto de sete vogais orais (cf. FERRAZ, 1979; MAURER 1995, 2009) e podem ser a principal influência para a opção do PVs. No entanto, essa hipótese precisa ser investigada por meio de estudos sobre outros processos fonológicos.

Na posição pretônica, assim como em algumas variedades do português (CÂMARA JR, 1995 [1970]; MATEUS \& D'ANDRADE, 2000; EMILIANO, 2009), os dados do PVS apresentaram uma redução no número de vogais, sendo que as vogais médias-baixas / $\varepsilon$, / são neutralizadas com as médias-altas /e, o/, sendo realizadas [e, o], significando a perda de um traço que distinga as vogais médias-altas das médias-baixas. Assim, no subsistema vocálico das pretônicas figuram cinco vogais orais, /i, u, e, o, a/, como mostrado em (16). Há ainda a aplicação variável do alçamento da vogal média-alta [e] pretônica, tornando-a um alofone da vogal [i], como em (17a). O mesmo ocorre com a vogal média-alta [o], como em (17b): 
(16) [i] cidade [si'dadr]

[e] seguro [se'gurv]

[a] salário [sa'larv]

[o] social [sosi'ał]

[u] sujeito [su'zetv]

(17) a. [e] cebola [si'bole]

b. [o] saboroso [sabu'rozv]

Assim, como na variedade europeia ${ }^{20}$, há uma tendência ao alçamento das médiasaltas pretônicas, porém, em PVS, os fonemas /e, o/ pretônicos são realizados como [i] e [u], respectivamente. Segundo Christofoletti (2010), a aplicação do processo de alçamento das vogais médias pretônicas no PVS está ligada à faixa etária do falante, sendo que os mais velhos possuem uma taxa de aplicação do processo de $57 \%$, enquanto os mais jovens possuem uma taxa de aplicação em 77\%. Portanto, no subsistema das pretônicas, verificase a redução vocálica, porém não de forma categórica, sugerindo uma mudança em curso. Essa mudança aponta para uma tendência à neutralização do [o] como alofone de /u/ e do [e] como alofone de /i/, como acontece na variedade europeia de Lisboa. Segundo a análise dos dados de Christofoletti (2010) no PVS, o subsistema vocálico pretônico é constituído por cinco vogais orais, [i, u, e, o, a], porém tende para o conjunto reduzido de três vogais $[i, u, a]$.

No subsistema vocálico das postônicas não-finais, há exclusivamente as palavras proparoxítonas. Christofoletti (2010) aponta que o conjunto das vogais realizadas nessa posição, no PVs, é [i, u, a]. Em (18), podemos observar os exemplos retirados do corpus de fala espontânea, em (18a), vemos como o fonema /e/ é neutralizado com o fonema /i/, sendo

\footnotetext{
${ }^{20} \mathrm{Na}$ variedade lisboeta do PE, o fonema /e/ pretônico pode ser realizado como [ə] ou [i] , e /o/ sendo realizado [u]; todavia esse processo não é categórico (MATEUS \& D'ANDRADE, 2000).
} 
realizado como [i]. Em (18b), o /o/ postônico não-final é neutralizado com o fonema /u/ realizado como $[\mathrm{u}]$, enquanto que em (18c), temos apenas um exemplo com o fonema /a/ sendo realizado como [a] por não ter ocorrido outro exemplo no corpus.

a. [i] $\rightarrow$ [i] católica [ka'tolike] [e] $\rightarrow$ [i] número ['nũmirv]

b. $[\mathrm{u}] \rightarrow[\mathrm{u}]$ estátua [if'tatue]

$$
[\mathrm{o}] \rightarrow[\mathrm{u}] \text { época ['epuke] }
$$

c. [a] $\rightarrow$ [a] sábado ['sabadv]

No sistema do PE descrito por Mateus \& d'Andrade (2000), é apresentado o conjunto dos seguintes fones na posição postônica não-final: [i, ə, u], enquanto que, no PB (variedade utilizada por CÂMARA JR, 1995 [1970]), é apresentado o seguinte conjunto: [i, u, e, o, a]. Assim como nas pretônicas, no PVS ocorre a neutralização das vogais médias /e, o/ com os fonemas $/ \mathrm{i}, \mathrm{u} /$, respectivamente, seguindo o padrão europeu, como nos exemplos: "época" ['Epuke], "número" ['nũmirv] e "área" ['arie]. Porém, diferentemente do PE, o schwa [ə] não aparece, portanto a vogal /a/ postônica não-final é realizada como [a], como nos exemplos: "sábados" ['sabadvf], "árabe" ['arabi] e "lâmpada" ['lãpade]. Desta forma, o que se verifica no subsistema das postônicas não-finais é que o PVS diferencia-se do subsistema tanto do PE (por não conter o schwa [ə]) quanto algumas variedades do PB (por não conter as vogais médias $[\mathrm{e}]$ e $[\mathrm{o}])$.

As silabas átonas finais são as mais fracas, uma vez que os valores conferidos como fraco/forte surgem da atribuição do acento primário (BISOL, 2003), como consequência, ocorre a neutralização das vogais presentes nessas sílabas (CÂMARA JR., 1995 [1970]). Tanto na variedade europeia, quanto na variedade brasileira, o conjunto de vogais nessa posição é formado por [i, u, a]. Porém, é importante ressaltar que isso não ocorre nas 
sílabas travadas por $/ \mathrm{l} / \mathrm{ou} / \mathrm{r} /$, uma vez que o preenchimento da coda com esses fonemas bloqueia o processo de alçamento (VIGÁRIO, 1999), como nos exemplos: "móvel" ['məveł] e "impossível" [ĩpu'siveł]. Já para as sílabas cujas codas contêm a consoante /s/, o alçamento da vogal ocorre de maneira semelhante às variantes do PE e do PB, como nos exemplos: 'Neves' ['nevif], 'simples' ['sĩplif] e 'Dolores' [du'lorif], ou ainda nos casos do morfema de plural "-s", realizado como [J], em que o alçamento também se aplica, como em 'eles' ['elif], 'domingos' [du'mĩgvf], 'cursos' ['kursvf] e 'frases' ['frazif]. Assim, no PVs, figuram apenas três vogais na posição postônica final: [i, u, a]. No Brasil, há estudos apontando que, em algumas variedades de português brasileiro, essa neutralização ainda não se completou, como em Bisol (2003), Lenzi e Brener (2008), Silva (2009), entre outros. Em (19), é apresentado um exemplo para cada fone. Vemos, no primeiro exemplo (19a), a vogal /i/ em sílaba átona final; em (19b), se encontra um exemplo com palavra terminada com a vogal /e/ realizada como [I], decorrente do alçamento vocálico aplicado em fim de palavra; em (19c), assim como no exemplo anterior, o alçamento vocálico foi aplicado na vogal /o/, a qual foi realizada como [ə]; no exemplo (19d), verificamos o alçamento ocorrendo na vogal /a/, que em final de palavra é realizada como [e]. Exemplos do PVs:

(19) a. [i] difícil [di'fisit]

b. [i] noite ['norti I]

c. [u] baixo ['ba $v]$

d. [a] deixava [de' $\left.\int a v e\right]$

Em síntese, no âmbito das tônicas, posição proeminente da palavra e considerada por Câmara Jr. (1995 [1970]) como o local onde é possível identificar os traços distintivos das vogais existentes, observou-se que, no PVS, o conjunto formado é de sete vogais orais: /i, u, e, o, $\varepsilon$, ə, a/. Nos demais contextos, o conjunto de vogais médias se reduz. Dessa forma, o 
conjunto das vogais pretônicas, que são mais fracas em comparação com as tônicas, perde

a distinção entre $[e]-[\varepsilon]$ e $[o]$ - $[\jmath]$, significando a elevação da vogal média-baixa para média-alta, formando assim um conjunto de cinco vogais na posição pretônica: /i, u, e, o, a/. Nas sílabas postônicas, posição mais fraca, ocorre o alçamento das vogais médias para altas. Assim, a oposição entre [e] - [i] e [o] - [u] desaparece e novamente o conjunto é reduzido, dessa vez para três vogais: [i, a, u].

\subsection{Interpretações sobre os ditongos no português}

Há estudos sobre os ditongos em variedades do português (principalmente no que concerne ao PB) alguns dos quais, elencados a seguir. Assim, para cumprir a proposta do presente trabalho, faz-se necessária uma breve apresentação dos principais resultados e teorias sobre as investigações dos ditongos aos quais tivemos acesso. Dessa forma, poderemos contrastar esses trabalhos com os resultados obtidos neste estudo.

Os ditongos são usualmente tratados como sequência de segmentos, sendo um desses segmentos interpretado como uma vogal e o outro segmento como um glide. Silva (2010) lembra que "do ponto de vista fonético, o que caracteriza um segmento como vocálico ou consonantal é o fato de haver ou não obstrução da passagem de corrente de ar pelo trato vocálico" (SILVA, 2010: 73). Ou seja, os segmentos vocálicos têm passagem livre, enquanto os segmentos consonantais apresentam obstrução ou fricção. Os glides, por outro lado, podem apresentar características fonéticas de um dos dois tipos de segmentos. O que irá determinar sua característica é a análise de sua função na estrutura sonora em cada língua em particular (SILVA, 2010).

Assim, os ditongos apresentam a mudança da qualidade de uma vogal, continuamente, no espaço de uma sílaba e são classificados de acordo com a referência ao segmento inicial e final desse contínuo. Por exemplo, na palavra ['pertø], notamos a passagem do segmento 
vocálico [e] para [I] em um movimento contínuo. Ambos os segmentos estão ocupando o espaço de uma sílaba, na qual um ocupa o núcleo dessa sílaba, nesse caso [e], e outro é considerado assilábico ${ }^{21}$, [I] (SILVA, 2010: 74), ocupando a margem da sílaba.

Os ditongos na língua portuguesa são classificados em dois tipos, dependendo da posição do glide em relação à vogal núcleo de sílaba: crescentes, ou seja, uma sequência glide-vogal (GV) e decrescentes, vogal-glide (VG). Os ditongos crescentes são constituídos por uma sequência de dois segmentos cuja saliência fônica recai no segundo segmento, deixando o primeiro assilábico, ou seja, uma sequência GV. Em Bisol (1991), a existência de tais ditongos é negada e a autora afirma que a língua portuguesa "não tem ditongos crescentes. O principal argumento é que o glide na sequência GV normalmente está em variação livre com a vogal homorgânica" (BISOL, 1991: 56). Para os casos de glide posterior precedido de consoantes velares e seguida pelas vogais /a/ ou /o/, como os exemplos "qual" ['kªw] e "quórum" ['kw analisado como uma unidade monofonemática. Sobre essas unidades, Silva (2010) também as considera como consoantes complexas, $\left[\mathrm{k}^{\mathrm{w}}, \mathrm{g}^{\mathrm{w}}\right]$, no entanto ela chama atenção para as palavras com o infixo -ion- (cf. "estacionamento, nacionalista, opcional, sensacional", etc.), as quais são realizadas obrigatoriamente como ditongos crescentes no português brasileiro. Couto (1994) defende a existência dos ditongos crescentes, inclusive no nível fonológico. O autor se utiliza do conceito de ambissilabicidade proposto por Clements \& Keyser (1993, apud COUTO, 1994) para comprovar a existência desse tipo de ditongo e utiliza como

\footnotetext{
${ }^{21}$ Assilábicos são os segmentos que não podem ocorrer como pico de sílaba, ou seja, ainda que se encontram na posição do núcleo silábico, não possuem a saliência fônica de uma vogal silábica. Nesses casos, na representação fonética, o elemento recebe o diacrítico [ ${ }_{\curvearrowleft}$, indicando sua assilabicidade.
} 
exemplo palavras que contém tritongos, como "Judeia, ideia, ceia, meia, apoia, boia, boiada, tapuia", etc., pois nessas palavras a realização do ditongo pode variar entre V-GV (ide-ia) ou VG-V (idei-a).

Em relação ao ditongo decrescente, ou seja, àquele cuja sequência é VG, a literatura aponta algumas divergências sobre a presença do glide na representação subjacente e sua posição dentro da sílaba no português. Câmara Jr. (1995 [1970]), adicionalmente, introduz ainda outra questão sobre os glides: essas vogais assilábicas devem ser consideradas consoantes ou vogais da língua portuguesa? Câmara Jr. afirma:

Considerar as vogais assilábicas como fonemas consonânticos é aumentar o número de consoantes portuguesas, mas em compensação diminuir os tipos portugueses de sílaba que cabe descrever. O contrário acontece se as interpretamos como alofones posicionais vocálicos. Há, entretanto, uma consideração que me parece preponderante em favor desta última solução. Refiro-me à possibilidade de se encontrar um $/ \mathrm{r} /$ brando depois do ditongo. Com efeito esta consoante só existe em português depois de vogal, onde cria uma oposição com o $/ \mathrm{r} /$ forte (...). Em face dessa propriedade fonêmica do $/ \mathrm{r} /$ fraco, a sua presença entre ditongo e vogal nos força a interpretar a vogal assilábica, mesmo em termos fonêmicos, como vogal (alofone assilábico de uma vogal, e, nunca, como uma consoante) (1995 [1970]: 46).

O argumento usado para considerar os glides como vogais (ou semivogais) pode ser estendido ao PVS, contudo, segundo Polycarpo (em preparação), a consoante tepe alveolar [r] não ocorre somente entre vogais, podendo aparecer também na posição de onset simples, como em "recurso" [re'kursv] e "respondeu" [respõ'dev]]; além de poder ocorrer como segundo elemento de onset complexo, por exemplo [bra'ziw] 22 "Brasil", e na coda: ['kursv] "curso"; portanto, no PVS não se pode aplicar o argumento utilizado por Câmara Jr. No entanto, após certos ditongos sofrerem monotongação, como em "motoqueiro" e "matandeiro" realizados no PVS respectivamente, como [moto'kes»] е [matã'des»], o tepe alveolar

\footnotetext{
${ }^{22}$ Nas transcrições fonéticas desse trabalho, quando o ditongo for formado pela vocalização da lateral /l/ pós-vocálico, o símbolo utilizado será [w] em detrimento do [vo]].
} 
não ocorre obrigatoriamente, diferentemente do PB e do PE, contrariando assim, o teste proposto por Câmara Jr. (1995 [1970]) descrito anteriormente.

Com relação à posição do glide dentro da estrutura silábica do português, Câmara Jr. postula que a sílaba composta por um ditongo decrescente segue o padrão (C)VV, estando o glide inserido no núcleo. Para justificar esse argumento, o autor cita a monotongação no português, como no exemplo do ditongo [oun] realizado como [o]. Cita, ainda, a variação livre do ditongo decrescente quando se encontra em posição átona, como no exemplo, vaida-de e va-i-da-de. Câmara Jr. defende a existência de onze ditongos decrescentes no Português, pois considera [əv] uma vogal seguida pela vocalização de /1/. Em (20), estão listados exemplos de palavras com cada uma das possibilidades de ditongo no português:

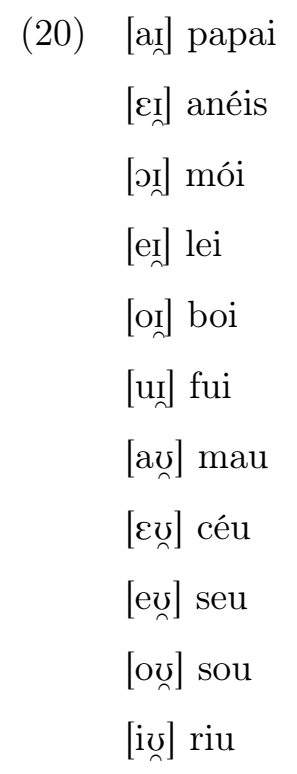

Quanto à posição do glide na estrutura silábica, Collischonn (1997) defende que esse se encontra na posição da coda silábica nos ditongos decrescentes. Para comprovar esse argumento, a autora mostra que não há sequências de ditongo decrescente seguido de consoantes líquidas na mesma sílaba em português, fato que comprovaria que os segmentos de líquidas e glides pós-vocálicos ocupam a mesma posição na sílaba, ou seja, a coda.

Para Bisol (1999), os glides não existem na representação subjacente. Tanto os ditongos crescentes quanto os decrescentes provém de duas vogais heterossilábicas. Na verdade, 
em Bisol (1989, 1994), os ditongos decrescentes são classificados de duas formas distintas: verdadeiros e falsos. Segundo a autora, os ditongos verdadeiros não são passíveis de redução, sendo constituídos por duas vogais na forma subjacente, enquanto os ditongos falsos são resultantes de espraiamento do nó vocálico da consoante que o segue (como se pode ver em (23)), desta forma, possuindo apenas uma vogal na forma subjacente. Bonilha (2000: 68) salienta que "de acordo com essa classificação, a forma subjacente dos ditongos que sofrem variação, ao ser constituída por apenas uma vogal, retira desses a possibilidade de sofrer monotongação". Portanto, segundo Bisol (1994), a existência do ditongo em "caixa" seria mera questão ortográfica.

(21) Ditongo verdadeiro

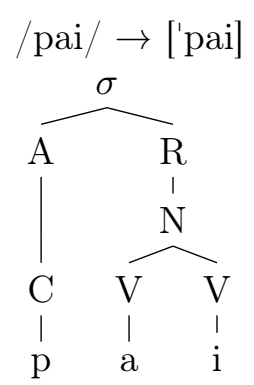

(22) Ditongo falso

$$
\begin{aligned}
& / \mathrm{caJa} / \rightarrow[\text { 'kaja] } \\
& \begin{array}{cc}
\mathrm{A} & \mathrm{R} \\
& \mathrm{N} \\
& \mathrm{N} \\
\mathrm{C} & \mathrm{V} \\
\mathrm{I} & \mathrm{I} \\
\mathrm{c} & \mathrm{a}
\end{array}
\end{aligned}
$$

Para ilustrar como é criado o espraiamento do nó vocálico, a seguir é demonstrado um exemplo apresentado por Bisol (2009), em que é possível ver o processo diante do tepe: 
$(23)$

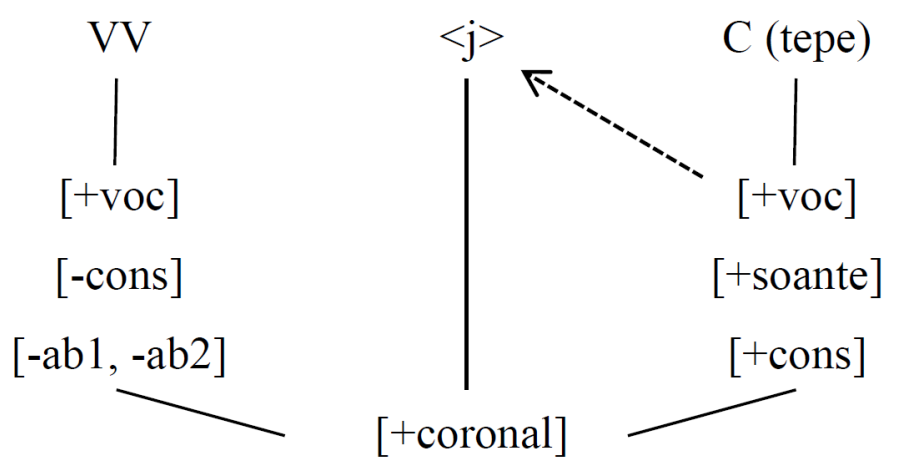

Figura 2.1: Criação do glide pelo espraiamento do nó vocálico do tepe.

Todavia, em relação à classificação dos ditongos em verdadeiros e falsos, encontramos dificuldades ao nos depararmos com os dados do PVS, assim como outras variedades de português africano, pois palavras que seriam classificadas como ditongos verdadeiros no português e, portanto, impossibilitadas de sofrer a monotongação como "direito" e "leite", no PVS são monotongadas, inclusive com alto índice de aplicação do processo. Assim, a divisão dos ditongos decrescentes entre verdadeiros e falsos se torna deficiente para o PVS.

Uma das evidências, apresentadas por Bisol (2009), de que o glide no ditongo variável é produto da expansão do traço vocálico presente na líquida, está na gramática do português. Nas palavras da autora:

A líquida lateral, que se realiza em português como lateral velar ou dorsal em posição pós-vocálica, tende a manifestar-se como glide posterior no português brasileiro, lençow por lençol, mew por mel. Todavia, diante de S-Plural, converte-se em glide coronal, em concordância com a coronalidade de /S/. Tal forma consagrada pela gramática do português é representada na escrita.

$$
\begin{aligned}
& \text { farol }+\{\mathrm{S}\} \quad[\text { fa'rojs }] \text { (faróis) } \\
& \mathrm{m} \varepsilon l+\{\mathrm{S}\} \quad[\text { 'mejs }] \text { (méis) } \\
& \text { koronel }+\{\mathrm{S}\} \quad[\text { koro'nejs] (coronéis). (2009: 7). }
\end{aligned}
$$

Com relação à posição do glide na estrutura silábica, Bisol (1999: 720) parte de uma condição para a boa formação da coda em português, a qual proíbe os segmentos não 
soantes, ou seja, as obstruintes, com exceção do fonema /S/. Dessa forma, as codas só podem ser formadas pelas soantes, ou seja, líquidas e nasais, e pelo fonema /S/. No caso de uma rima formada com a estrutura $\mathrm{VC}_{1} \mathrm{C}_{2}$ (cf. "perspectiva, solstício"), é aplicada a regra de adjunção de /S/, na qual um arquifonema /S/ é inserido em uma coda bem formada. Assim, o $\mathrm{C}_{1}$ só pode ser ocupado por uma soante e o $\mathrm{C}_{2}$, por $/ \mathrm{S} /$.

A mesma condição, para Bisol (1999), é aplicada aos glides dos ditongos decrescentes, já que eles ocupam a coda e compartilham a propriedade [+soante], podendo, portanto, preencher a posição de coda silábica. Como contra-argumentos à Mateus \& D'Andrade (2000), Bisol cita: i) as vogais longas, representantes de núcleos ramificados, não fazem parte do inventário fonológico do português; e ii) o português não possui sequência de ditongos decrescentes mais líquidas na mesma sílaba, uma vez que o glide ocupa essa posição, como se verifica na inexistência de palavras formadas por essa combinação. Portanto, neste trabalho aceitaremos a proposta de Bisol (1999), entendendo que o glide do ditongo decrescente, no PVS, encontra-se posicionado na coda silábica.

Uma descrição dos ditongos por meio da análise do português europeu (variante falada em Lisboa) pode ser encontrada no trabalho de Mateus \& D'Andrade (2000). Segundo esses autores, os glides que aparecem na superfície são todos provenientes de vogais altas subjacentes (seja as que constituem ditongos crescentes ou decrescentes). Para defender tal posição, usam como argumento o fato de não haver contraste entre vogais e glides no PE, como pode ser comprovado pela inexistência de pares como ['paI] (CVV) e ['paj] (CVC) com significados distintos. Assim, para que uma vogal alta se torne um glide nos ditongos decrescentes basta que a ela seja atribuída uma marca em sua representação lexical que a impeça de receber o acento e seja antecedida por uma vogal. Em relação à posição do glide dentro da sílaba, os autores assumem que esse segmento faz parte do núcleo (análise diferente da proposta por Bisol), compartilhando-o com a vogal mais proeminente. Como 
argumento, eles exemplificam que na formação de ditongos nasais, como em "mão" ['mã్̃ ], tanto a vogal como o glide são nasalizados. Com o mesmo argumento, sustentam que nas palavras realizadas com ditongos crescentes, como em "criança" e "pião", a não nasalização do glide pré-vocálico indicaria que esse se encontra na posição de onset, e não no núcleo, uma vez que a nasalização não é aplicada.

Portanto, as opiniões no que concerne ao glide, se vocálico ou consonantal, e à sua posição na estrutura silábica, se no núcleo ou nas adjacências (onset e coda), ainda são discutidas e esperamos que os resultados alcançados neste trabalho possam vir a contribuir com as hipóteses atuais, pois, como será visto no capítulo 3, a aplicação da monotongação de alguns ditongos é influenciada por restrições fonotáticas ligadas à posição de coda. Assim, esse fato corrobora a teoria sobre os glides do ditongos decrescentes não se encontrarem no núcleo da sílaba.

\subsection{Realização de ditongos em algumas variedades do português}

Nesta seção, trazemos um breve resumo de trabalhos sociolinguísticos voltados para a descrição da realização dos ditongos em algumas variedades do português brasileiro. Os ditongos mais estudados são [eI], [aI] e [oữ], por serem os mais suscetíveis à aplicação da monotongação (veremos adiante que essa suscetibilidade também se confirmou no PVs). Posteriormente, compararemos os resultados alcançados neste trabalho com os de outros pesquisadores em outras variedades.

O trabalho de Meneghini (1983) buscou pesquisar os ditongos orais decrescentes nos falantes de Ibiaçá (RS). Por meio da observação de variáveis linguísticas, como o contexto seguinte e a tonicidade, e extralinguísticas, como a zona rural ou urbana, o sexo e a idade, 
o autor observou como esses fatores poderiam influenciar na monotongação. De todos os ditongos pesquisados, o autor encontrou variação em apenas três: [ey], [ay] e [ow] ${ }^{23}$, os demais alcançaram resultados categóricos na não aplicação do processo de apagamento do glide. A variável contexto seguinte foi determinante para a monotongação dos ditongos. Em [ey], a regra só se aplica diante dos segmentos [r], [f], [3] ou [g]; já em [ay], o apagamento do glide verifica-se na presença da consoante $\left[\int\right]$. Quanto ao [ow], a regra aplica-se em qualquer ambiente não tendo, assim, relação com o contexto. No que concerne às variáveis extralinguísticas, a única relação encontrada pelo autor foi com a variável idade, a qual mostrou uma tendência, não muito acentuada, de os mais velhos empregarem mais a forma monotongada do que os mais jovens. Segundo Araújo (1999: 57), "não há uma tentativa de explicação dos resultados obtidos. O autor [Meneghini] se preocupa apenas em descrever o fenômeno em função dos contextos estipulados para tal".

Paiva (1996) trabalhou com a variedade de português falada no Rio de Janeiro, analisando a variação em dois ditongos, o [ow] e o [ey]. Seu corpus contava com 3133 dados, nos quais não havia ditongos em final de palavra, pois, segundo a autora, não ofereciam variação, mantendo-se o glide em [ey] e apagando-se o glide em [ow]. A hipótese norteadora do trabalho era que a supressão das semivogais se dava de forma sistêmica e condicionada essencialmente por fatores de ordem estrutural, como contexto seguinte e tonicidade da sílaba, e não social. A autora também buscava evidências de que a supressão de [y] e [w] são dois processos distintos, com motivações fonéticas diferenciadas. As variáveis elencadas por Paiva foram: a extensão da palavra, ponto e modo de articulação do elemento imediatamente seguinte ao ditongo, a tonicidade da sílaba em que ocorreu o ditongo e incidência da variável no radical ou no sufixo do item lexical. Além das variáveis linguísticas,

\footnotetext{
${ }^{23}$ Decidimos preservar a forma original como os autores grafaram e se referiram aos ditongos em seus trabalhos. Dessa forma, [ey] é o ditongo [eI], [ay] é o ditongo [aI] e [ow] é como foi representado o ditongo [ov].
} 
a autora considerou ainda algumas variáveis sociais, como: o grau de escolaridade, idade e gênero. Contudo, a análise contemplou apenas o ditongo [ey] e os resultados obtidos com relação às variáveis sociais foram inexpressivos, corroborando a hipótese inicial de que a monotongação é motivada principalmente por fatores linguísticos. Foram consideradas estatisticamente relevantes as variáveis ponto e modo de articulação, a extensão da palavra e a estruturação interna da palavra.

Quanto ao ponto de articulação, os segmentos com peso relativo maior e, portanto, os que mais contribuíram com a aplicação da monotongação do ditongo [ey] foram: os segmentos velares, que tiveram o peso relativo de 0,89 e os alveopalatais, com 0,93 ; enquanto que os segmentos dentais $(0,15)$, os alveolares $(0,27)$ e as vogais $(0,10)$ não favoreceram a regra. Porém, a autora salienta que os valores relativos às velares estão limitados à monotongação na palavra "manteiga", razão pela qual ela os excluiu. Quanto ao modo de articulação, o que mais favorece a supressão de [I] é o tepe com 0,99, assim como as fricativas com 0,56. Os demais segmentos agem como inibidores do processo: oclusivos com 0,13 , nasais com 0,13 e laterais com 0,25 .

A explicação para os altos índices de monotongação exibidos pelos segmentos alveopalatais, fricativos e tepe, segundo Paiva, está em considerar a monotongação como um processo de assimilação decorrente de segmentos fonéticos idênticos contíguos ao ditongo. Dessa forma, quando o segmento seguinte ao ditongo apresenta alguns traços em comum com o glide, este é cancelado. Os segmentos alveopalatais compartilham com o glide os traços $[+$ alto $]$ e [+coronal]. Contrariamente, os alveolares e dentais possuem o traço [-alto], justificando seu efeito bloqueador. O [r] apresenta "o maior número de propriedades vocálicas" (PAIVA, 1996 apud ARAÚJO, 1999: 60), como os traços [+sonorante] e [+contínuo]. Assim, o traço [+contínuo] é o responsável pelo efeito de cancelamento do glide [y].

Um contra-argumento a essa hipótese seria a manutenção do ditongo quando este 
se encontra diante de vogal, como nas palavras "assembleia", "alheio", já que as vogais compartilham traços idênticos aos dos glides, como o [+contínuo] presente no tepe e nas fricativas, todavia, isso não é suficiente para apagá-los. Para justificar esse comportamento discrepante, a autora aponta este procedimento como uma tendência geral da língua para evitar a formação de hiatos.

Outra variável que se mostrou sensível à aplicação da regra, no ditongo [ey], foi a extensão da palavra. Os pesos relativos de cada possibilidade estão apresentados a seguir: monossilábicas com peso relativo de 0,07 ; dissilábicas com 0,67 ; trissilábicas com 0,71 ; e polissilábicas com 0,71. Estes números indicam que as palavras monossilábicas restringem o processo de monotongação, enquanto que a partir das palavras dissilábicas a monotongação é favorecida.

O último grupo de fatores linguísticos selecionados no trabalho de Paiva (1996) foi a estruturação interna das palavras. Nessa variável, a autora identificava a localização do ditongo morfologicamente, ou seja, se os ditongos estavam localizados no sufixo ou no radical do item lexical. Os resultados do peso relativo foram 0,61 para os sufixos e 0,38 para os ditongos no radical. Desse modo, o contexto mais favorável à aplicação da monotongação de [ey] seria quando este estivesse localizado em um sufixo. Todavia, a autora ressalta que esses resultados estão ligados a uma provável sobreposição das variáveis: estruturação interna das palavras e características do segmento fonético seguinte ao ditongo, já que os números se relacionam com um único sufixo derivacional, o "-eiro", este formado pelo tepe, segmento fonético que, como visto anteriormente, é grande favorecedor da aplicação da regra. Assim, esse resultado pode estar ligado à presença do tepe e não à posição morfológica. Paiva conclui que a monotongação de [ey] pode ser considerada um processo próximo do categórico quando o contexto seguinte contiver segmentos alveopalatais ou tepe. A autora também conclui que são duas regras de motivações fonéticas que interferem no processo, 
sendo ambas com relação à contiguidade de segmentos: a primeira compartilhando ponto de articulação (segmentos alveopalatais); e a segunda, modo de articulação (tepe).

No que diz respeito ao ditongo [ow], os resultados de Paiva (1996) apontam que a regra de monotongação é aplicada independentemente do contexto linguístico. Desse modo, os resultados corroboram a hipótese de que a monotongação do ditongo [ow] está mais avançada do que a de [ey]. A evidência para essa afirmação está no fato de, além de não se sujeitar às restrições do segmento seguinte, o peso relativo da aplicação da monotongação de [ow] alcança o valor de 0,98, enquanto que o ditongo [ey] está submetido a restrições de contexto e um índice de aplicação da regra no valor de 0,61. Assim, a autora conjetura que a monotongação de [ow] já esteja concluída e implementada no sistema. Todavia, salienta que possam existir restrições de ordem lexical, exigindo uma investigação mais precisa em termos de difusão lexical.

Cabreira (1996) pesquisou as variedade de português das cidades de Curitiba, Florianópolis e Porto Alegre. Seu objetivo principal era investigar a relação entre fatores linguísticos e extralinguísticos na aplicação do processo de monotongação dos ditongos [ay], [ey] e [ow] nos dialetos citados. O autor ainda buscou verificar se havia semelhança entre as variedades das taxas de aplicação da monotongação. O corpus utilizado totalizava 3765 ocorrências na primeira análise e 5988 ocorrências na segunda análise. Com relação às variáveis escolhidas, o autor elencou sete linguísticas: contexto seguinte, sonoridade do elemento seguinte, natureza morfológica do ditongo, posição do elemento quanto à sílaba, tonicidade da sílaba, valor fonemático do ditongo, estrutura profunda do ditongo; e quatro variáveis extralinguísticas: sexo, idade, escolaridade e variedade geográfica.

Entre as variáveis linguísticas, destaca-se a atuação da variável natureza morfológica do ditongo, pois esta foi importante para indicar uma aplicação maior da regra de monotongação nos radicais das palavras dos ditongos [ey] e [ay] seguidos por palatal e para o 
ditongo [ey] seguido por tepe. Segundo Cabreira (1996), esse resultado contradiz os dados de Paiva (1996), pois, no trabalho dessa autora, a regra se dava fortemente no sufixo da palavra. Sobre essa diferença, Cabreira observa que em sua análise, no caso de [ey] seguido por tepe, se restringiu às ocorrências do ditongo apenas diante de $[\mathrm{r}]$, enquanto que Paiva incluía todas as ocorrências do ditongo em seu trabalho. Assim, ele aponta que a sua análise ganha vantagem, já que evita a superposição entre os dois fatores em destaque. Contudo, Paiva (1996), como vimos, já havia alertado sobre essa possibilidade de superposição em seu trabalho.

A primeira variável elencada, relevante para os ditongos [ey] e [ay] seguidos por [f] ou [3], foi a posição do elemento seguinte quanto à sílaba. Essa variável demonstrou que a monotongação é maior quando o elemento seguinte está em outra sílaba (peso relativo de 0,92) do que quando o elemento seguinte se encontra na mesma sílaba $(0,02)$. Cabreira afirma que esse resultado fortalece a proposta de Bisol (1989: 189-190), segundo a qual a monotongação é mais aplicada em ditongos em sílabas leves (mai.se.na) do que em ditongos em sílabas pesadas (mais). A próxima variável, sonoridade do elemento seguinte, mostrou que para os ditongos [ey] e [ay] seguidos por palatais, a aplicação da regra diante da fricativa surda $\left[\int\right](0,58)$ é maior do que diante da sonora [3] $(0,22)$, ambos os resultados foram parecidos tanto no ditongo [ey] quanto no ditongo [ay].

No que concerne ao ditongo [ow], o contexto seguinte não tem nenhum papel significativo na aplicação da regra de monotongação corroborando os resultados alcançados por Paiva (1996). O valor fonemático do ditongo indicou que os ditongos fonemáticos (nos termos de Bisol, 1991) ${ }^{24}$ são os menos suscetíveis à monotongação. Para o autor, a baixa

\footnotetext{
24"fonemático é aquele tipo de ditongo cuja redução à vogal simples cria uma homonímia, como em 'couro $\rightarrow$ coro', observe-se que a forma resultante da redução coincide com outra palavra já existente na língua, o substantivo masculino 'coro'. O segundo tipo de ditongo, dito não fonemático, pode ser reduzido sem que disso resulte uma homonímia, como em 'pouco $\rightarrow$ poco'" (LOPES, 2002: 31)
} 
frequência de aplicação da regra em ditongo dessa natureza (peso relativo de 0,40) sugere uma motivação funcional que é evitar ambiguidade. No entanto, o próprio autor se questiona quanto a isso, dada a alta incidência de apenas dois itens lexicais: vou e ou, sem redução.

A única variável extralinguística selecionada pelo programa, escolaridade, obteve resultado semelhante para os ditongos [ey] e [ay], indicando que os indivíduos de baixa escolaridade são os que mais aplicam a regra. Esses resultados poderiam corroborar a suposição de que o contato com a norma escrita, proporcionado pela escola, viesse inibir o uso da forma não padrão. No entanto, com respeito ao ditongo [ow], esse resultado se revela diferente dos ditongos [ey] e [ay]: os números apontam para uma menor aplicação da regra entre os falantes com $2^{\underline{O}}$ grau (peso relativo de 0,39 ), enquanto que, entre aqueles que estudaram até a $5^{\mathrm{a}}$ série, este número sobre para 0,51 , e aqueles que têm até a $8^{\mathrm{a}}$ série apresentam um índice um pouco mais expressivo de redução do ditongo $(0,58)$.

Mollica (1998) investigou o processo de monotongação dos ditongos [ey] e [ow] em estudantes de três escolas do Rio de Janeiro, duas públicas e uma particular. O corpus da pesquisa foi composto pela produção escrita de alunos desde a fase de alfabetização até a terceira série do segundo grau; para cada série, foram subdivididos dois grupos: um que recebeu orientações explícitas a respeito das regras de monotongação na fala ${ }^{25}$ e outro que não as receberam. O objetivo da pesquisa era estabelecer a ligação entre o fenômeno de variação e o processo de aquisição da escrita como pressuposto básico para uma pedagogia bem orientada e dirigida e preparação de materiais didáticos específicos para solucionar problemas relacionados à língua escrita na escola. Destacam-se como

\footnotetext{
25"Estabeleceu-se que para uma das turmas, o pesquisador explicitaria que, na língua oral, muitas vezes deixamos de pronunciar determinados sons que não chegam a causar danos na comunicação. Todavia, é indispensável saber que devemos representar esses sons em forma de grafemas na língua escrita de acordo com as normas ortográficas vigentes" (MOLLICA, 1998: 56).
} 
resultados mais relevantes alcançados neste estudo: (a) as turmas de alfabetização e de $1^{\mathrm{a}}$ série mostraram-se indiferentes a um comando explícito sobre a influência da fala na escrita, começando a assimilar diferenças entre o oral e o escrito apenas a partir da $2^{\mathrm{a}}$ série; (b) a forma "correta" de /ey/ foi aprendida mais rapidamente em comparação a /ow/. Segundo Mollica, "quanto mais operado o processo na língua falada, tanto mais resistente é a aprendizagem das regras de escrita" (1998: 59); (c) no decorrer das séries, a monotongação de /ey/ e /ow/ tendem a reduzir-se de maneira mais rápida quando houve a orientação específica nesse sentido; (d) o sexo feminino tende a monotongar menos. Todavia, na $1^{\mathrm{a}}$ e $3^{\mathrm{a}}$ séries, foram os meninos que monotongaram menos. A autora salienta que essa diferença costuma ser maior em turmas em que o nível socioeconômico é mais baixo. Ressalta ainda que as mulheres tendem a aderir mais facilmente às formas standard, motivadas pelo "prestígio encoberto"26; (e) quanto à instrução realizada na sala de aula no momento da pesquisa, os casos de monotongação de /ey/, houve mais eficácia pedagógica do que nos casos de monotongação de /ow/.

Araújo (1999) pesquisou a alternância entre [e्న] e [e] no português falado na cidade de Caxias (MA), em uma perspectiva sincrônica e com metodologia baseada nos pressupostos da Teoria da Variação. O corpus é composto de dados coletados de gravações, de aproximadamente 30 minutos cada uma, da fala de informantes previamente selecionados e estratificados com base no sexo, no grau de instrução e na idade. O total de dados coletados pela autora foi de 1305, os quais foram submetidos ao pacote de programas VARBRUL

26"O termo prestígio encoberto (covert prestige) foi empregado por Labov (1966) para indicar a forte sensibilidade feminina às formas linguísticas padrão. Essa tendência feminina tem recebido diferentes explicações, na sua maioria ligadas ao papel mais efetivo da mulher na socialização da criança. Responsável pela transmissão das normas de comportamento social, dentre elas a linguística, à mulher cabe a obrigação de ser o modelo exemplar. Dessa forma, a atenção da mulher às formas linguísticas de prestígio pode ser vista como manifestação de uma tendência mais geral ao 'bom' comportamento. De forma geral, permite-se ao homem e não à mulher a quebra de regras sociais, fato que se reflete no comportamento linguístico (cf. Chambers \& Trudgil, 1980)" (ARAÚJO, 1999: 66) 
para as devidas análises estatísticas. As variáveis linguísticas controladas foram: contexto fônico precedente, segmento seguinte, sonoridade do elemento seguinte, posição do ditongo, tonicidade da sílaba, dimensão do item lexical e velocidade da fala. As variáveis extralinguísticas foram as mesmas da estratificação: idade, escolaridade e sexo, e a classe social do falante.

A variável segmento seguinte foi considerada a mais relevante para o processo de monotongação. Os dados mostram maior incidência de monotongação quando o ditongo se encontra diante de tepe (peso relativo de 0,85$)$ e de vogal central baixa [a] $(0,61)$, como nas palavras 'feira' e 'cadeira', 'meia' e 'feia', respectivamente; enquanto que um baixo índice desse fenômeno se manifesta diante de $[\mathrm{n}](0,12)$ e de [3] $(0,18)$, como nas palavras 'treino' e 'feijão'. Diante dos segmentos [ []$(0,46)$ e [g] $(0,47)$, o índice de monotongação é intermediário. A autora chama atenção para o fato de que o segmento tepe é o que concentra o maior número de ocorrências (479 de 541), quase a metade de todo o corpus. Esse fato faz “(...) suspeitar que o fenômeno de simplificação do ditongo [eI] tenha se originado diante do segmento $[r]$ e não diante de [S] ou de [3], conforme mencionado por Lemle (1978: 69)" (VEADO, 1983 apud ARAÚJO, 1999: 80).

A variável escolaridade se mostrou igualmente relevante para a aplicação da regra de monotongação, todavia, os dados estão divididos em apenas duas categorias: escolarizados e não-escolarizados. Confirmando a hipótese, os indivíduos escolarizados (peso relativo de 0,35$)$ aplicam menos a regra de monotongação do que os falantes não-escolarizados $(0,63)$. Para Araújo, a relevância desta variável nos dados demonstra que a regra de monotongação no dialeto de Caxias (MA) possui diferenciação diastrática, ou seja, este fenômeno está ligado a diferenças de ordem, o que demonstra a ação inibidora da escola em relação à implementação do fenômeno. Desta forma, o contato da variedade oral com 
a norma padrão e com a escrita acarreta uma modificação no comportamento linguístico dos falantes, os quais passam a usar menos a forma monotongada.

Na próxima seção, apresentaremos alguns aspectos da fonologia das línguas crioulas que fornecerão aporte para a interpretação de alguns comportamentos na realização dos ditongos verificados no capítulo 3 desse trabalho.

Em síntese, neste capítulo, foram discutidos alguns estudos sobre o ditongo no português, tanto na variedade brasileira quanto europeia, entre eles, destacaram-se as obras de Câmara Jr. (1995 [1970]), Bisol (1991) e Mateus \& D’Andrade (2000). Concordamos com a proposta de Bisol (1991, 1994) e Collischonn (1997), segundo a qual o glide do ditongo decrescente se encontra na coda silábica. Para corroborar com essa escolha, analisamos a fonologia das línguas crioulas faladas em STP, observando que estas línguas evitam a formação de sílabas fechadas por ditongos, ou seja, evitam o preenchimento da coda, aplicando, entre outros processos, a monotongação. Vimos também a proposta de Bisol sobre a existência de ditongos verdadeiros e falsos, estes últimos ganhando essa classificação por serem formados em decorrência de espraiamento do nó vocálico da consoante seguinte e assim, decidimos excluir de nossa análise os ditongos formados no nível fonético, como "mês" ['meÎన]] e "três" ['treI J]], por não conterem o ditongo na forma subjacente. Também não entraram em nosso trabalho a análise dos ditongos crescentes, pois, segundo Bisol (1991), estes estariam em variação livre entre a realização como ditongo ou hiato, sendo negada pela autora sua existência na língua portuguesa. 


\section{Capítulo 3}

\section{Discussão e análise dos dados}

\subsection{Introdução}

Neste capítulo, apresento os ditongos do corpus, a análise estatística dos dados e a interpretação dos resultados. A seguir, é apresentada a discussão sobre as estatísticas absolutas do processo de monotongação nos dados. Por fim, divididas em subseções, estão as análises individuais de cada ditongo documentado no corpus.

\section{$3.2 \quad$ A análise}

O corpus de nossa dissertação é composto por 3017 ocorrências de ditongos registrados ortograficamente, dessas, 816 correspondem a dados com o ditongo [eI]; 606 com ditongo [oI]; 588 com ditongo [oun]; 469 com o ditongo [aI]; 387 com ditongo [ev్ ]; 37 com ditongo

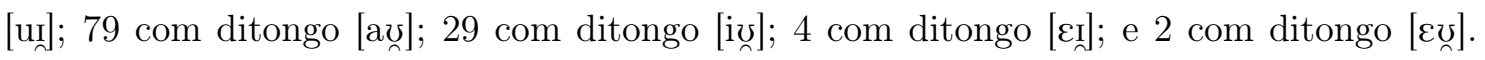

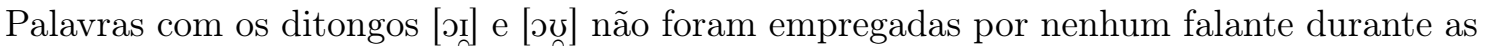
gravações, assim, não há dados no corpus contendo esses ditongos. A seguir, é apresentada uma tabela com os dados acima descritos: 


\begin{tabular}{|c|c|}
\hline Ditongo & Ocorrências \\
\hline [eI] & 816 \\
\hline [OI] & 606 \\
\hline [ov] & 588 \\
\hline [aI] & 469 \\
\hline [ev్ ] & 387 \\
\hline [av] & 79 \\
\hline [uI] & 37 \\
\hline [ivo] & 29 \\
\hline$[\varepsilon \mathrm{I}]$ & 4 \\
\hline [عv] & 2 \\
\hline [כI] e [כઇ్ ] & 0 \\
\hline Total & 3017 \\
\hline
\end{tabular}

Tabela 3.1: Número de ocorrências para cada ditongo presente no corpus.

De forma absoluta, após a primeira rodada dos dados no Goldvarb 2001, foi observado que o processo de monotongação foi aplicado em $49 \%$ do total de dados com ditongos,

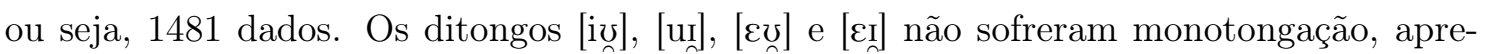
sentando, assim, resultados categóricos (knockouts). Dessa forma, houve a necessidade de se fazer análises independentes para cada ditongo, uma vez que o resultado alcançado na análise feita com todos os ditongos em conjunto não reflete a situação individual dos ditongos. Além disso, a literatura (cf. MENEGHINI, 1983; PAIVA, 1996; CABREIRA, 1996; MOLLICA, 1998 e ARAÚJO, 1999) sobre as realizações variáveis dos ditongos comumente apresenta análises individuais, em sua maioria do ditongo [eI] e do ditongo [oun], devido à sua alta produtividade e variação na aplicação da regra de monotongação (caso do ditongo [e्స]) ou à aplicação categórica da monotongação (como é o caso do ditongo $[\mathrm{ov}])^{27}$. A seguir, faremos observações independentes acerca de cada ditongo, para que, ao fim, possamos comparar os resultados alcançados aos já observados sobre as realizações dos ditongos em outras variedades de português.

\footnotetext{
${ }^{27}$ Meneghini (1983) estudou todos os ditongos, porém encontrou variação em apenas [ay], [ey] e [ow]. Cabreira (1996) analisou os ditongos [ay], [ey] e [ow]. O trabalho de Paiva (1996) abarcou os ditongos [ey] e [ow]. Mollica (1998) observou a influência da escolaridade na realização dos ditongos [ey] e [oy]. Por fim, Araújo (1999) observou a alternância entre [ey] e [e].
} 


\subsection{Ditongos}

\subsubsection{Ditongo [eI]}

O processo de monotongação do ditongo [eI] foi tratado por Teyssier (2001 [1989]), o qual diz que a monotongação acabou não sendo totalmente incorporada no português contemporâneo, apesar do amplo número de falantes que monotongavam o [er] , por causa de Lisboa, onde se encontravam os falantes que mantinham o ditongo. Teyssier conclui que:

Difícil é precisar quando se produziu, no Sul de Portugal, a monotongação de ei. No teatro da segunda metade do século XVIII, e por ei caracteriza o falar das personagens populares do Alentejo (ex.: sardenhero por sardinheiro). A monotongação era, pois, um fato consumado naquela data. É de crer, no entanto, que as suas primeiras manifestações fossem mais antigas. (TEYSSIER, 2001 [1989]: 53)

Das 3017 ocorrências do corpus, foram filtradas as que continham o ditongo [eI] presente na forma subjacente. Assim, restaram 816 palavras, das quais apenas 291 (35\%) não sofreram processo de monotongação.

Carregados os dados, na primeira rodada no software Goldvarb 2001, algumas das variáveis retornaram resultados categóricos, como o contexto subsequente e número de sílabas da palavra, havendo assim a necessidade de reorganizar os dados, uma vez que, não havendo variação em algum contexto, o programa deixa de mostrar corretamente informações importantes para a devida análise estatística. Assim, ocorreram duas situações que exigiram a recodificação. A primeira foi no ditongo [eI] diante de $/ \mathrm{k} / \mathrm{ou} / \mathrm{g} /$, pois tivemos apenas uma única ocorrência desse ditongo nesse contexto, foi na palavra "manteiga", realizada como [mã'tege]. A mesma situação foi verificada no trabalho de Paiva (1996); para resolver esse knockout, assim como a autora, optamos por não incluir essa única ocorrência 
na rodada seguinte, entendendo que essa ação não prejudica os demais resultados. A segunda situação ocorreu devido a 11 palavras que possuíam cinco sílabas, todas elas foram monotongadas, gerando assim o knockout. Decidimos classificar essas palavras junto com as palavras de quatro sílabas, o que formaria o grupo das "polissílabas".

Tomadas essas ações, partimos para a segunda rodada do programa para verificar os dados cruzados, de forma a observar quais variáveis o programa retornaria como eliminados e quais seriam significantes para a aplicação da monotongação. As variáveis eliminadas foram: tonicidade, posição morfológica e sexo do informante, ou seja, nesses dados (do ditongo [eI] ) essas três informações são consideradas não influentes para a aplicação do processo de monotongação. A melhor rodada selecionada pelo programa, cuja significância foi de 0,04 (quanto mais próximo de zero, maior a significância da rodada) e o input ${ }^{28}$ de 0,75 , selecionou as seguintes variáveis linguísticas: contexto seguinte, classe da palavra, posição do ditongo na palavra, e número de sílabas da palavra. As variáveis sociais elencadas foram idade e escolaridade.

Em relação à variável contexto seguinte, observamos que nas 524 palavras (64\% das 816) que sofreram monotongação, como esperado, o processo de monotongação ocorreu com mais frequência em contexto diante de róticos (PR de 0,96$)$, grupo no qual se encontra o tepe (98\% das 316 palavras nesse contexto foram monotongadas), como pode ser visto em (24). Os exemplos são apresentados com a grafia oficial do português, seguidas das transcrições fonéticas do PVS:

${ }^{28}$ Esse dado representa o nível geral de uso de determinado valor da variável dependente. 
(24) car.tei.ra [ka.'te.re]

di.nhei.ro [di.'ne.sv]

cu.ran.dei.ro [ku.ьã.'de.sv]

en.fer.mei.ra [en.fe.'me.re]

Diante das consoantes pós-alveolares fricativas ([j] e [3]) 95\% das 125 palavras nesse contexto sofreram monotongação, (PR de 0,94), como mostrado em (25). Ressaltamos que o processo se deu igualmente em sílaba pretônica (25a e 25b) ou tônica (25c):
a. a.lei.ja.da [a.le.'za.de]
b. dei.xa.va [de.'Sa.ve]
c. pei.xe ['pe.Ji]

Um dado que já havia chamado atenção no início do estudo foi o ditongo diante da consoante oclusiva alveolar [t] em posição posterior ao ditongo, por não ocorrer de forma sistemática em estudos sobre a realização dos ditongos nas variedades do PB apresentadas no capítulo 2. No PE, apenas uma região parece monotongar esse ditongo diante de [t]: a ilha de São Miguel, no Açores, segundo Bernardo \& Montenegro (2003 apud RUA, 2005), a monotongação de [eI] encontra grande vitalidade em São Miguel, em palavras como leite ['let]e beira ['bere]. Além de confirmado, o contexto do ditongo diante de [t] no PVS mostrou-se como uma variação estável no processo de monotongação ( $81 \%$ das 80 palavras nesse contexto foram monotongadas, PR de 0,50 ), lembrando que apesar da alta porcentagem de aplicação, o valor que importa é o do peso relativo, pois ele indica se o contexto é favorável ou não. A aplicação do processo se dá independentemente se a sílaba for tônica (26a), átona (26b) ou ainda quando se encontra no início (26b) ou meio da palavra (26c e 26d). 
(26) a. di.rei.to [di.'se.tv]

b. fei.ti.ço [fe.'ti.sv]

c. a.zei.te [a.'ze.ti]

d. sa.tis.fei.to [sa.trf.'fe.tv]

Ao confrontar os pesos relativos dos casos em que houve a monotongação com os que não houve, dentro de cada contexto, observa-se que a aplicação da monotongação é bastante elevada em quase todos os contextos. Quando diante das fricativas pós-alveolares o PR é de 0,94; da oclusiva alveolar surda [t], é de 0,50; dos róticos, chega aos 0,96; diante das nasais, ou seja, [n] ou [m], há variação, ora não aplicando a monotongação como em "reino"

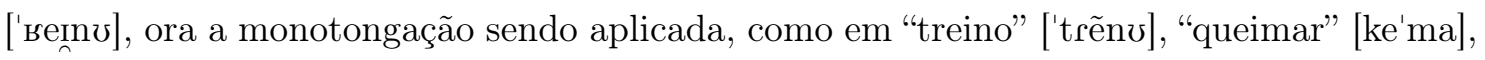
"treinar" [tвe'na], porém, o peso relativo é de 0,23 , indicando um contexto desfavorável para a aplicação do processo. Vale lembrar que a ditongação diante de nasal, no PB, quando ocorre, são nessas mesmas palavras e cognatos. Quando diante das fricativas alveolares [s] e [z], como em "seis e" ['sezi], o peso relativo é de 0,65, indicando um contexto favorecedor para a aplicação do processo de monotongação. No entanto, o quadro se inverte quando no contexto seguinte está uma vogal (0,002), ou seja, sua relevância fica praticamente anulada. Nesses casos, vemos uma aproximação aos resultados dos dialetos do sul do Brasil e um distanciamento à variedade de Caxias (MA) (ARAUJO, 1999). No PVS, quando o contexto seguinte é fim de palavra $(0,007)$, o que, em quase todos os dados, significou que a classe da palavra era um verbo (conjugado na primeira pessoa do singular do pretérito perfeito, i.e., "cheguei", "viajei", "sentei", etc.), com a única exceção da palavra "lei", que não é um verbo. Nesse caso, houve o bloqueio da monotongação do ditongo [e्ન], pois a monotongação desse 
ditongo acarretaria a perda de uma informação morfológica, no caso a informação de tempo e pessoa do verbo, sugerindo que a variável classe de palavra se mostraria importante ${ }^{29}$.

Quando a consoante seguinte era uma velar, ou seja, [g], só obtivemos um exemplo, "manteiga" [mã'tege], e foi monotongado, resultando um knockout no Goldvarb 2001, o que significa a não presença de variação. A Tabela 3.2 apresenta os resultados:

\begin{tabular}{cccccc}
\hline Contexto & Monotongo & Não-monotongo & Total & \%Aplicada & Peso Relativo \\
Róticos & 312 & 4 & 316 & 98 & 0,963 \\
3, $\int$ & 119 & 6 & 125 & 95 & 0,939 \\
s, z & 6 & 7 & 13 & 46 & 0,651 \\
t, d & 65 & 15 & 80 & 81 & 0,501 \\
n, m & 19 & 2 & 21 & 90 & 0,228 \\
pausa & 2 & 202 & 204 & 99 & 0,007 \\
vogais & 1 & 55 & 56 & 1 & 0,002 \\
k, g & 1 & 0 & 1 & 100 & - \\
\hline
\end{tabular}

Tabela 3.2: Aplicação da monotongação do [eI] cf. contexto fonético seguinte.

Pode-se observar que os contextos verificados como favorecedores da monotongação no PVS, o tepe ou a fricativa palato-alveolar, também se verificaram no PB (na variedade de Altamira/PA, cf. LOPES, 2002). No entanto, as possíveis realizações do arquifonema / R/ em coda, no PVs, seguem um padrão não documento no $\mathrm{PB}$, sendo o / $\mathrm{R} /$ realizado como $[\mathrm{в}]$ (fricativa uvular vozeada) com maior frequência. Assim, podemos inferir que a característica dos traços das consoantes em contexto seguinte, ao menos no PVs, não seja a única responsável pelo processo de monotongação que ocorre nessa variedade, uma vez que, apesar de róticos, os fones $[\boldsymbol{r}]$ е $[в]$ possuem ponto e modo de articulação distintos. Assim, a influência das línguas crioulas faladas em STP desempenha um papel importante, pois apesar do santome não possuir róticos na posição de coda, essa língua, assim como as demais línguas autóctones, não possui ditongos decrescentes.

\footnotetext{
${ }^{29}$ Todavia, como veremos no caso do ditongo [ov] em fim de verbo flexionado, mesmo esse sendo também um ditongo que carrega uma informação morfológica (terceira pessoa do singular, pretérito perfeito), esse fato não se mostra determinante para bloquear a monotongação, sendo esta aplicada categoricamente.
} 
Esses resultados se aproximam daqueles alcançados na variedade de português brasileiro do Rio de Janeiro (cf. PAIVA, 1996). A seguir, a tabela comparativa apresenta os valores entre as duas variedades.

\begin{tabular}{ccc}
\hline Contexto Seguinte & PVS & PB (PAIVA, 1996) \\
f & 0.96 & 0.99 \\
3, $\mathrm{s}$ & 0.94 & 0.93 \\
s, z & 0.65 & 0.53 \\
t, d & $\mathbf{0 . 5 0}$ & $\mathbf{0 . 1 3}$ \\
n, m & $\mathbf{0 . 2 3}$ & $\mathbf{0 . 1 3}$ \\
pausa & 0.01 & - \\
vogais & 0.00 & 0.00 \\
k, g & 0.00 & 0.00 \\
\hline
\end{tabular}

Tabela 3.3: Comparativo entre o PVS e o PB do Rio de Janeiro.

Nota-se que, na Tabela 3.3, os contextos cujos valores se distanciam mais, entre o PVS e oPB, é diante de /t, d/ e /n, m/. Essa discrepância entre as duas variedades pode ser influência do santome, lung'ie ou angolar, sobre o PVS, pois como mostrado em 2.1, as línguas autóctones não possuem ditongos decrescentes e, assim, as palavras nessas línguas que continham ditongo na origem portuguesa, foram monotongadas. Dessa forma, ditongos que em português são mantidos, como nos casos de contexto diante de /t, d/ passam a sofrer monotongação.

No ditongo [eI], a influência da classe de palavra como fator para a aplicação da monotongação pode ser explicada por consequência de [eI] ser um morfema flexional dos verbos da primeira conjugação, sendo produtivo e frequente, uma vez que flexiona o verbo para a primeira pessoa do singular do pretérito perfeito. Do total de 816 palavras com ditongos, $275(33 \%)$ eram formas verbais, dessas, apenas em 64 palavras (23\%) foi aplicada a monotongação. Como vimos, na posição final de palavra, o ditongo não é monotongado e, em $23 \%$ dos casos, há verbos em que o ditongo se encontra na posição medial e não representa o morfema flexional, como nas palavras "aproveita", "aleija", "deixa", etc. Na Tabela 3.4, estão apresentadas as porcentagens e pesos relativos na oposição verbos e não-verbos. 


\begin{tabular}{ccccc}
\hline Classe & Monotongo & Não-monotongo & Total & Peso Relativo \\
Verbos & $64(23 \%)$ & $211(77 \%)$ & 275 & 0,328 \\
Não-verbos & $460(85 \%)$ & $80(15 \%)$ & 540 & 0,804 \\
\hline
\end{tabular}

Tabela 3.4: Porcentagem e peso relativo da variável classe da palavra [eI].

Pôde-se observar que o peso relativo do "Não-verbos" é de 0,80 , número considerado alto. A princípio, denota o fato de a palavra ser um não-verbo supostamente favorecer a aplicação da monotongação. Todavia, é preciso observar que, dessas 460 palavras que sofreram o processo de monotongação, apenas 3 ocorrências de uma mesma palavra ("dezesseis") possuem o ditongo [eI] na posição final. Assim, a próxima variável escolhida pelo programa, posição do ditongo dentro da palavra, pode ser a maior responsável pelo processo de monotongação do ditongo [eI] .

Como apresentado na seção 1.4, classificamos as palavras considerando três possibilidades de posição dos ditongos, sendo: posição inicial, posição medial e posição final. Se a palavra for um monossílabo, consideramo-las como em posição inicial. Em dissílabos, a segunda sílaba será considerada final. Nas palavras com três ou mais sílabas, todas as ocorrências de ditongos entre a primeira e última sílaba são consideradas mediais. Das 816 palavras, 280 contavam com o ditongo em posição inicial, sendo monotongadas $62 \%$ delas, alcançando um peso relativo de 0,51 , indicando assim uma variação estável. Na posição medial, $93 \%$ das 370 palavras foram monotongadas, o peso relativo chegou a 0,81 , indicando um contexto altamente favorecedor da monotongação. Este alto índice no peso relativo pode ser explicado por ser a posição medial a mais suscetível às variáveis linguísticas como acento, contexto seguinte e número de sílabas. Por outro lado, apenas $1 \%$ das 165 palavras em posição final foram monotongadas, cujo peso relativo alcançado foi $0,03, \mathrm{o}$ que indica um contexto desfavorecedor para a monotongação. Esse dado corrobora nossa 
hipótese, apresentada no parágrafo anterior, que o fato da variável "Classe" ser selecionada tem relação com a posição do ditongo e não com a classe de palavra. A Tabela 3.5 apresenta os valores de forma organizada.

\begin{tabular}{ccccc}
\hline Posição & Monotongo & Não-monotongo & Total & Peso Relativo \\
Inicial & $174(62 \%)$ & $106(37 \%)$ & 280 & 0,514 \\
Medial & $347(93 \%)$ & $23(6 \%)$ & 370 & 0,815 \\
Final & $3(1 \%)$ & $162(98 \%)$ & 165 & 0,031 \\
\hline
\end{tabular}

Tabela 3.5: Resultados da variável posição do ditongo [ê]].

Quanto à variável número de sílabas, documentamos 59 palavras monossílabas que continham o ditongo [eI], 277 dissílabas, 366 trissílabas e 114 polissílabas. Os pesos relativos apontam para uma variação estável nas palavras mais longas, trissílabas $(0,46)$ e polissílabas $(0,54)$, enquanto que as dissílabas se mostram como favorecedoras ao processo de monotongação com peso relativo de 0,63 . Já os monossílabos se apresentam como contexto inibidor da monotongação do ditongo [er], com peso relativo de 0,15. A seguir, a Tabela 3.6 demonstra os valores citados.

\begin{tabular}{ccccc}
\hline No Sílabas & Monotongo & Não-monotongo & Total & Peso Relativo \\
Monossílabas & $12(20 \%)$ & $47(79 \%)$ & 59 & 0,154 \\
Dissílabas & $146(52 \%)$ & $131(47 \%)$ & 277 & 0,629 \\
Trissílabas & $270(73 \%)$ & $96(26 \%)$ & 366 & 0,456 \\
Polissílabas & $97(85 \%)$ & $17(14 \%)$ & 114 & 0,539 \\
\hline
\end{tabular}

Tabela 3.6: Resultados da variável número de sílabas para o ditongo [eي].

A respeito das variáveis sociais, duas foram selecionadas pelo Goldvarb 2001 como significantes. Primeiro, verificou-se uma relação da aplicação do processo de monotongação do ditongo [eI] com a quantidade de anos de escolaridade. As pessoas mais escolarizadas tendem a evitar mais a monotongação ( $58 \%$ de aplicação do processo, peso relativo de 0,270) do que as pessoas menos escolarizadas (69\% de aplicação do processo e peso relativo 0,643). Na faixa intermediária, ou seja, das pessoas com escolaridade entre três e nove anos, a taxa de aplicação do processo de monotongação se apresenta em $61 \%$ das palavras e o peso 
relativo 0,483. Assim, o que podemos observar na Tabela 3.7 é uma progressão conjunta entre a quantidade de anos de escolaridade com a probabilidade de ocorrer a monotongação, ou seja, quanto mais anos de escolaridade o falante tiver, menor a probabilidade de ocorrer o processo.

\begin{tabular}{ccccc}
\hline Escolaridade & Monotongo & Não-monotongo & Total & Peso Relativo \\
Baixa & $240(69 \%)$ & $103(30 \%)$ & 343 & 0,643 \\
Média & $177(61 \%)$ & $112(38 \%)$ & 289 & 0,483 \\
Alta & $108(58 \%)$ & $76(41 \%)$ & 184 & 0,270 \\
\hline
\end{tabular}

Tabela 3.7: Resultados da variável escolaridade do ditongo [ẽ्].

Devido às características sócio-históricas da formação do país e à relação dessa formação com as políticas educacionais ${ }^{30}$, as variáveis escolaridade e idade não estão diretamente relacionadas. A faixa etária primeira, que abrange indivíduos dos 15 aos 25 anos, não necessariamente contém apenas indivíduos com baixo número de anos de escolaridade. Há ainda o fator qualidade de ensino: os indivíduos mais velhos, cuja escolarização foi obtida durante a era colonial, apesar do baixo número de anos de escolaridade, possuíam, em grande parte, uma desenvoltura muito maior no que diz respeito ao domínio da norma culta $^{31}$ da língua portuguesa. Essa desenvoltura está ainda relacionada com a exigência social de se dominar o "português correto". Durante os relatos gravados, os próprios informantes mais velhos, por vezes, lamentam a baixa qualidade do ensino nos dias atuais e o baixo domínio do "português culto" por parte dos mais jovens. Observando os resultados dos pesos relativos em relação à idade, como esperado, percebemos que os mais jovens aplicam mais a monotongação (peso relativo de 0,723$)^{32}$, uma vez que são considerados

${ }^{30}$ Como exposto na seção 1.3.1, STP passou por três fases sócio-histórias que transformaram as políticas educacionais, começando pelo período da colonização (antes de 1975), depois, o período comunista (de 1975 a 1990), no qual foram tomadas medidas para a escolarização universal das crianças, e, por fim, o período capitalista (pós 1990), o qual se encontra até os dias atuais e existe um esforço para combater o analfabetismo nos adultos.

${ }^{31}$ Por norma culta, em São Tomé e Príncipe, considera-se a norma lusitana.

${ }^{32}$ Acima de 0,5 indica favorecimento da aplicação da monotongação, abaixo desse valor, indica desfavorecimento. 
mais inovadores no que diz respeito ao uso da língua. A taxa de aplicação da regra vai diminuindo gradualmente conforme a idade aumenta (peso relativo de 0,489 ), confirmando os mais velhos como mais conservadores no que diz respeito ao uso da língua (peso relativo 0,269). A Tabela 3.8 apresenta os números relacionados aos dados da variável idade:

\begin{tabular}{ccccc}
\hline Idade & Monotongo & Não-monotongo & Total & Peso Relativo \\
Faixa 1 & $188(68 \%)$ & $85(31 \%)$ & 273 & 0,723 \\
Faixa 2 & $173(59 \%)$ & $119(40 \%)$ & 292 & 0,489 \\
Faixa 3 & $163(65 \%)$ & $87(34 \%)$ & 250 & 0,269 \\
\hline
\end{tabular}

Tabela 3.8: Resultados da variável Idade do ditongo [er].

Ao compararmos os resultados das variáveis idade e escolaridade, vemos que ambas formam uma linha decrescente, como aparece na Figura 3.1:

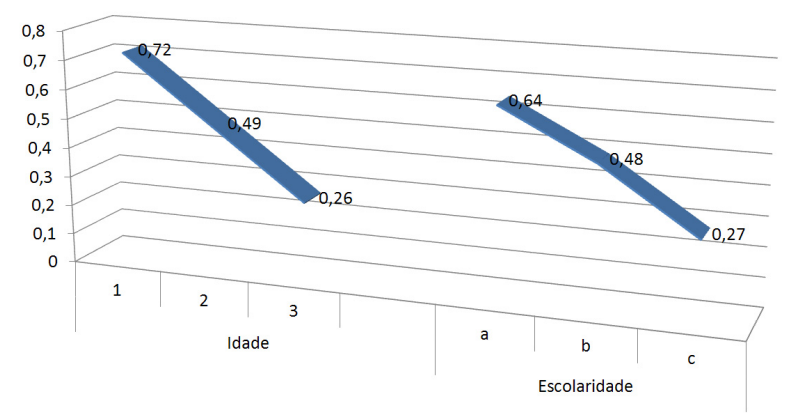

Figura 3.1: Comparação das variáveis escolaridade e idade na monotongação de [eI] (pesos relativos).

Os resultados da variável escolaridade corroboram outros estudos sobre a influência da escolarização na aplicação da monotongação do ditongo [eI] nas variedades brasileiras de português analisadas por Silva (1997), Araújo (1999) e Lopes (2002). Esses autores também verificaram que, quanto maior o tempo de escolaridade, menor a porcentagem de aplicação da monotongação.

Figueiredo (2012) analisou a variável escolaridade na marcação do plural do sintagma nominal do português falado em Almoxarife, uma região específica de STP, e também verificou a relação da marcação com o nível de escolaridade dos informantes. Porém, o autor chama a atenção para os fatores históricos do desenvolvimento e execução do sistema 
educacional, assim como o modo de aprendizado do português como L2 por gerações passadas recentes, fator que também pode justificar os índices de aplicação do processo de monotongação verificado no ditongo em questão.

Em síntese, verificamos que, no ditongo [eI], a taxa de aplicação do processo de monotongação está relacionada aos anos de escolaridade do indivíduo, e as variáveis significantes para a possibilidade de aplicação são principalmente o contexto seguinte ao ditongo e a posição do ditongo dentro da palavra. Os contextos seguintes mais significantes são os mesmos observados por outros estudos em variedades brasileiras, com exceção de quando o contexto é um /t/. Este fato pode estar ligado à influência da língua santome, cujas palavras que continham ditongos, provindas do português, são monotongadas por razões estruturais da língua.

\subsubsection{Ditongo [oI]}

O ditongo [oI] foi documentado em 606 dados, sendo monotongado em $35 \%$ deles. As palavras que puderam ser monotongadas foram "depois" [di'pof] e "coisa" ['koze]. Essas palavras foram altamente frequentes, correspondendo a $35 \%$ e $28 \%$ das 606 , respectivamente. A palavra "depois" foi a maior responsável pelo aumento do número de ocorrências de casos de monotongação (176), ou seja, 83\%. A palavra "coisa" foi monotongada apenas três vezes (cerca de 2\%). Ao retirar essas palavras, a monotongação é aplicada apenas uma vez na palavra "dezoito" [di'zotv]. Assim, a análise da variação da realização do ditongo fica prejudicada, não sendo possível a aplicação da análise estatística por meio do Goldvarb 2001. Organizamos a Tabela $3.9 \mathrm{com}$ as palavras mais frequentes ${ }^{33}$, exibindo número de frequência e porcentagem de aplicação de monotongação em cada palavra. Além das duas

\footnotetext{
${ }^{33}$ Os 'Outros vocábulos', citados na tabela são, nomeadamente: Toyota, oito, oitavo, oitenta, oi, noite, noitinha, goiaba, goiabeira, doido, boi, biscoito e apoio.
} 
mais frequentes citadas anteriormente, vemos que a palavra "foi", terceira mais frequente, não sofreu monotongação. Já a palavra "dois" possui alto índice de monotongação, $71 \%$.

\begin{tabular}{lcc}
\hline & $\begin{array}{c}\text { Frequência do vocábulo } \\
\text { no corpus }\end{array}$ & $\begin{array}{c}\text { Frequência da monotongação } \\
\text { no vocábulo }\end{array}$ \\
\hline Depois & $213 / 606=35 \%$ & $173 / 213=83 \%$ \\
Dois & $52 / 606=8 \%$ & $37 / 52=71 \%$ \\
Coisa & $168 / 606=28 \%$ & $3 / 168=2 \%$ \\
Foi & $69 / 606=11 \%$ & $0 / 69=0 \%$ \\
Outros vocábulos & $104 / 606=18 \%$ & $1 / 104=0,96 \%$ (dezoito) \\
\hline
\end{tabular}

Tabela 3.9: Palavras mais frequentes contendo o ditongo [or].

Observando as variáveis linguísticas, nota-se que o bloqueio da monotongação em "foi" pode ser justificado por ser o ditongo a marca de flexão do verbo. No caso da palavra "dois" e "depois", a aplicação variável da monotongação parece ser influência do contexto seguinte, o [J] em coda. Se considerarmos as observações de Bisol, vistas no capítulo 2, essas palavras se encaixariam na categoria dos ditongos falsos, sendo o "i" um registro meramente ortográfico, pois o glide seria criado devido ao espraiamento do nó vocálico de [f]. No entanto, é importante lembrar que a monotongação dessas palavras, tanto no PB quanto no PE, não são comuns. No caso do PE, foi registrado por Maia (1975 apud RUA, 2005) no falar da região de Algarve, possibilidades de monotongação em palavras como "pois" e "bois", em que o ditongo [oI] se encontra posicionado em posição de final de palavra e antes de uma consoante fricativa sendo realizado como ['pof] e ['bof]. Ou seja, a monotongação de [or] não é encontrada no PB (ao menos nas variedades citadas neste trabalho), todavia, é encontrada no PE e marginal também no PVS.

\subsubsection{Ditongo [ov ]}

Das 588 palavras presentes no corpus com o ditongo [oữ], houve apenas 3 ocorrências de não aplicação do processo de monotongação, uma vez na palavra "pouco", uma na palavra "ou" 
e uma na palavra "estou", independente do contexto ou posição na palavra, evidenciando uma aplicação categórica do processo. Não havendo variação, a análise pelo programa Goldvarb 2001 se mostra inócua.

Das palavras monotongadas, $57 \%$ representam verbos, a maioria sendo na forma do pretérito dos verbos terminados em -ar, como: "acabou" [aka'bo], "gostou" [gof'to], "revoltou" [revo'to]. Mas também ocorreu em outras formas verbais como: "sou" ['so] e "ouvi" [o'vi]. Houve ainda a monotongação nos não-verbos, como visto em (27). Esses resultados estão em concordância com o que Câmara Jr. (1995 [1970]: 56) observou sobre o ditongo [ovg] na variedade do PB (variedade culta do Rio de Janeiro) analisada pelo autor, ou seja, sua representação é meramente ortográfica, sendo monotongado no registro informal. No PE, segundo Rua (2005), a própria variedade considerada padrão, a de Lisboa, tem estabelecida a monotongação dos ditongos [oun]. Segundo Teyssier (2001), a monotongação de [oun] está registrada desde o século XVII, distribuindo-se, hoje, pela área central e sul de Portugal (havendo apenas uma ilha de ditongação em Leiria), já no Norte de Portugal, área mais conservadora, o ditongo está presente. A seguir, estão exemplos de monotongação nas palavras extraídas do nosso corpus:

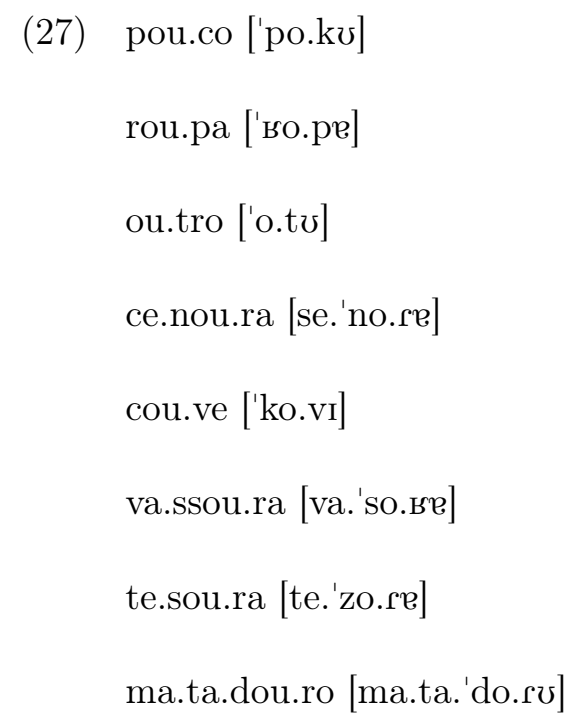




$$
\begin{aligned}
& \text { ou.ri.ço [о.'เi.sv] } \\
& \text { cri.ou.lo [kri.'o.lv] }
\end{aligned}
$$

Assim, no PVS, o ditongo [ov] se comporta como nas demais variedades de português possuindo uma taxa de monotongação praticamente categórica em qualquer contexto linguístico. Os anos de escolaridade não influenciam na diminuição dessa taxa de monotongação, o que corrobora a hipótese de que o processo foi totalmente assimilado.

\subsubsection{Ditongo [aI]}

No corpus de 3017 palavras, há 469 palavras contendo o ditongo oral [ar] dessas, 122 (26\%) foram monotongadas. O contexto mais produtivo, na primeira rodada do Goldvarb 2001, deu-se antes da consoante fricativa $\left[\int\right]$, como mostrado nos exemplos em (28). No entanto, a aplicação não é categórica, sendo mantido o ditongo em alguns exemplos, como apontado em (29):

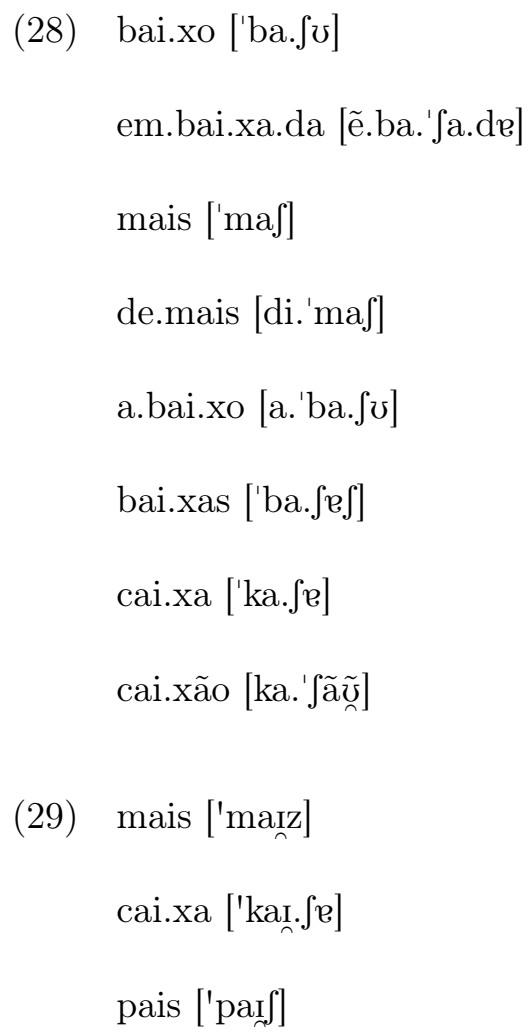


vais ['vaIf]

in.ter.na.ci.o.nais [ĩ.ter.na.si.o.'naI J]

tex.tu.ais [tef.tu.'arf]

Nesse ditongo, a proposta de Bisol (2009) para o PB parece poder ser aplicada também ao PVS, uma vez que o nó vocálico da consoante seguinte pode ou não ser espraiado, como demonstrado no capítulo 2. Quando o contexto seguinte contiver uma vogal, como em "praia" ou "maior", manter o ditongo se torna necessário para evitar hiatos.

Assim como fizemos no ditongo [eI] , juntamos as palavras com cinco sílabas às de quatro sílabas, formando a categoria dos polissílabos. A variável contexto seguinte apresentou variação apenas nos contextos diante de $\left[3, \int\right]$ e $[z, s]$. Quando o ditongo se encontrava em fim de palavra, foi categoricamente mantido (165 palavras, 35\% do total de palavras com ditongo [ar]), assim como quando diante de vogal (42 palavras, 8\%), diante de /v/ (apenas 2 palavras, "gaivota" e "raiva") e diante de /1/ (uma única palavra, "tailandeses"). Como podemos observar na Tabela 3.10 .

\begin{tabular}{ccccc}
\hline Contexto & Monotongo & Não-monotongo & Total & \%Aplicada \\
3, $\int$ & 81 & 110 & 191 & 42 \\
s, z & 41 & 27 & 68 & 60 \\
pausa & 0 & 165 & 165 & 0 \\
vogais & 0 & 42 & 42 & 0 \\
f, v & 0 & 2 & 2 & 0 \\
l & 0 & 1 & 1 & 0 \\
\hline
\end{tabular}

Tabela 3.10: Aplicação da monotongação do [aI] cf. contexto fonético seguinte na primeira rodada.

A variável classe de palavra também retornou resultado categórico no que se refere aos verbos, ou seja, todos mantiveram o ditongos, apenas havendo a monotongação nos dados não-verbos, como podemos ver na Tabela 3.11 . 


\begin{tabular}{ccccc}
\hline Classe & Monotongo & Não-monotongo & Total & \%Aplicada \\
não-verbo & 122 & 216 & 338 & 36 \\
verbo & 0 & 131 & 131 & 0 \\
\hline
\end{tabular}

Tabela 3.11: Aplicação da monotongação do [å] cf. classe de palavra.

Para poder analisar a variação nos casos do ditongo [aIn, trabalhamos com os dados contendo o ditongo diante de $\left[3, \int\right]$ e $[\mathrm{z}, \mathrm{s}]$ e cuja classe fosse a dos não-verbos, totalizando 255 dados. Na rodada binomial, os grupos descartados foram: tonicidade do ditongo, posição do ditongo na palavra, tamanho da palavra e sexo do informante. A melhor rodada selecionada obteve a significância de 0,05 (quanto mais próximo esse valor estiver de zero significa que o conjunto de variáveis escolhidas possui grande significância para a ocorrência do processo) e input de 0,50 e as variáveis significantes foram: contexto seguinte, posição do ditongo na palavra e as variáveis sociais idade e escolaridade.

Em relação ao contexto seguinte, os maiores pesos relativos ficaram nos contextos de $[\mathrm{z}, \mathrm{s}](0,61)$, cuja porcentagem de aplicação do processo de monotongação foi de $64 \%$. Na Tabela 3.12 podemos verificar os demais resultados detalhados.

\begin{tabular}{cccccc}
\hline Contexto & Monotongo & Não-monotongo & Total & \%Aplicada & P.R. \\
s, z & 41 & 27 & 64 & 60 & 0,611 \\
3, $\int$ & 81 & 110 & 191 & 42 & 0,462 \\
\hline
\end{tabular}

Tabela 3.12: Aplicação da monotongação do [aI] cf. contexto fonético seguinte na segunda rodada.

Na variável posição do ditongo na palavra, observamos uma maior aplicação da monotongação quando o ditongo se encontra no meio ou no fim do vocábulo, como podemos observar na Tabela 3.13.

\begin{tabular}{cccccc}
\hline Posição & Monotongo & Não-monotongo & Total & \%Aplicada & P.R. \\
Inicial & 99 & 125 & 224 & 44 & 0,441 \\
Medial & 7 & 1 & 8 & 87 & 0,901 \\
Final & 16 & 7 & 23 & 69 & 0,826 \\
\hline
\end{tabular}

Tabela 3.13: Aplicação da monotongação do [aI] cf. contexto fonético seguinte na segunda rodada. 
Nesse ditongo, chamou-nos a atenção uma variável que não foi controlada na classificação, mas que pode influenciar nas aplicações do processo de monotongação. Apesar de termos controlado o contexto seguinte, não foi classificado se esse contexto estaria na mesma sílaba do ditongo (ou seja, se o fonema seguinte seria a coda da sílaba onde se encontra o ditongo ou o onset da sílaba seguinte ao ditongo). Baseado nos dados do nosso corpus, a monotongação ocorre mais quando o [j] se encontra na sílaba seguinte, na posição de onset, enquanto a aplicação se torna menor quando o $\left[\int\right]$ está na posição de coda, na mesma sílaba do ditongo, ou seja, a fronteira morfológica da sílaba pode estar agindo como bloqueadora do processo de espraiamento, como vemos em (30).

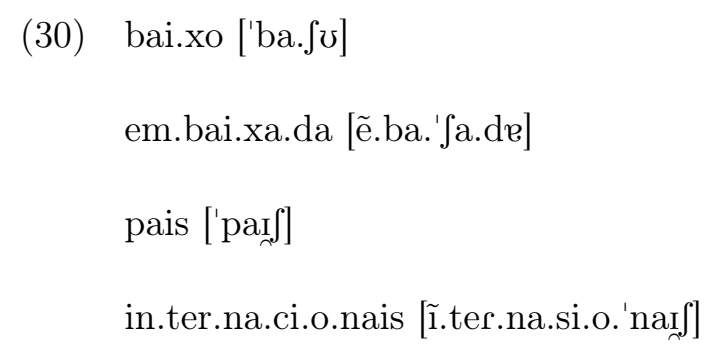

O que pudemos notar, com relação às variáveis sociais, é que a realização do ditongo [aI] possui uma curva no que diz respeito aos anos de escolarização. Vemos que, na faixa mais baixa (a), possui um peso relativo de 0,41 , ou seja, não favorece a aplicação do monotongo, enquanto esse peso sofre um aumento na faixa intermediária (b), indo para 0,59, tornando-se favorecedor da monotongação, mas torna a cair na faixa de escolaridade alta (c), atingindo 0,40, indicando um desfavorecimento, porém apontando para uma estabilização da aplicação do processo. Os detalhes podem ser vistos na Tabela 3.14

\begin{tabular}{ccccc}
\hline Escolaridade & Monotongo & Não-monotongo & Total & Peso Relativo \\
Baixa & $23(39 \%)$ & $35(60 \%)$ & 58 & 0,414 \\
Média & $74(56 \%)$ & $56(43 \%)$ & 130 & 0,586 \\
Alta & $25(37 \%)$ & $42(62 \%)$ & 67 & 0,408 \\
\hline
\end{tabular}

Tabela 3.14: Resultados da variável escolaridade do ditongo [ar]. 
Mais uma vez, a hipótese para esses resultados pode estar relacionada com a faixa etária dos falantes e a qualidade de ensino à qual foi submetido, todavia isso ainda precisa ser provado por meio de estudos que foquem a relação entre idade, anos de estudos e períodos históricos aos quais se frequentou a escola. Na Tabela 3.15, podemos observar a curva formada também na variável idade.

\begin{tabular}{ccccc}
\hline Idade & Monotongo & Não-monotongo & Total & Peso Relativo \\
Faixa 1 & $29(41 \%)$ & $41(58 \%)$ & 70 & 0,482 \\
Faixa 2 & $33(37 \%)$ & $54(62 \%)$ & 87 & 0,359 \\
Faixa 3 & $60(61 \%)$ & $38(38 \%)$ & 98 & 0,638 \\
\hline
\end{tabular}

Tabela 3.15: Resultados da variável idade do ditongo [ar].

Na Figura 3.2, vemos que a curva é totalmente diferente da vista na Figura 3.1 para o ditongo [ễ], aqui vemos como a idade não está ligada à variável escolaridade, possuindo curvas invertidas.

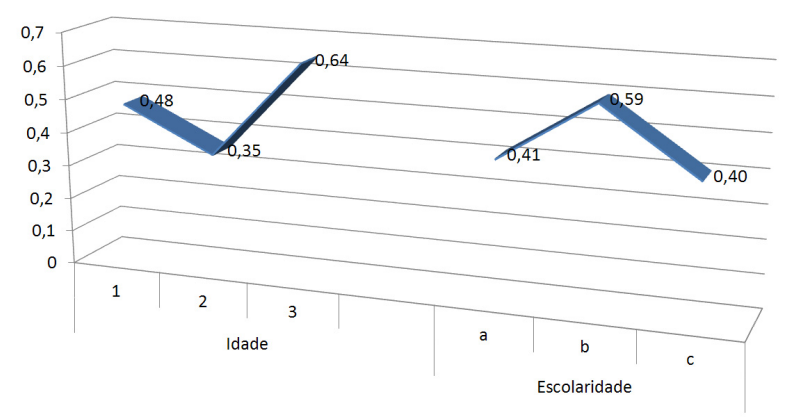

Figura 3.2: Comparação das variáveis escolaridade e idade na monotongação de [aI] (pesos relativos).

Em síntese, o ditongo [ar], diferente do que ocorreu ao ditongo [eI], tem sua taxa de monotongação aumentada quando o indivíduo possuí o nível médio de anos de escolaridade. Enquanto em relação à idade, a monotongação sobe nos indivíduos mais velhos. Quando o processo de monotongação ocorre, ele está ligado ao contexto seguinte ao ditongo, o que se mostrou bastante influente na aplicação do processo. O principal elemento fonético é o arquifonema /S/. Porém, verificamos que, quando este elemento fonético representa um morfema de plural ou está na mesma sílaba do ditongo, a taxa de monotongação é menor. 


\subsubsection{Ditongo [ev]}

No corpus, o ditongo [ev్ ] teve 387 ocorrências, com aplicação do processo de monotongação em apenas $5 \%$ dessas palavras. Dessa forma, o ditongo [eư] se apresenta como não sendo favorável ao processo de monotongação e, assim, a utilização do programa Goldvarb 2001, usado para observar variações, se mostra precária. Todavia, se faz interessante notar algumas características do comportamento de algumas realizações desse ditongo. A vocalização da lateral /1/, formando o ditongo [ew], foi verificada em apenas duas palavras, a saber, "impossível" [ĩpo'sivew] e "possível" [po'sivew]. Isso se deve ao fato de o processo de vocalização da lateral, diferente do PB, não ser amplamente aplicado, sendo mais comum a realização da lateral, em posição de coda, como uma lateral velarizada [ł]. Na língua portuguesa, o ditongo [ev ] é produtivo por causa da forma flexionada dos verbos no pretérito perfeito (correu, morreu, cedeu, etc). No corpus, 51 das 387 ocorrências (13\%) são de formas verbais, das quais nenhuma sofreu monotongação. De fato, houve apenas 22 casos de monotongação (5\%) do ditongo [ev̛], exemplos em (32c), a maioria na palavra "euro" ['erv] e no pronome possessivo "meu" ['me], esse último apresentando grande recorrência. Em Naro \& Scherre (2010), os autores afirmam que, no trabalho de Ferreira (1994: 32 apud NARO \& SCHERRE, 2010) sobre o português falado em Helvécia ${ }^{34}$, o processo de monotongação do [eṿ̛] nos pronomes possessivos seria de natureza "crioulizante", porém ressaltam que a redução de "meu", "teu", "seu" a, respectivamente, "me", "te", "se" fora documentada no português europeu não padrão (cf. LEITE DE VASCONCELLOS, 1987/1901: 109; CRUZ, 1991: 110; ALVES, 1993: 181 apud NARO \& SCHERRE, 2010). No entanto, no caso do PVS, o uso do "me" em detrimento do "meu" está possivelmente relacionado à influência do santome, cujo pronome possessivo de primeira pessoa, de origem portuguesa,

\footnotetext{
${ }^{34}$ Distrito que fica no extremo sul da Bahia, no município de Nova Viçosa, e tem aproximadamente 4 mil moradores.
} 
é "me". O que presenciamos aqui é possivelmente o caminho inverso acontecendo (léxico santome indo para a variedade oral do português), já que não há nenhum indício de que o processo ocorra devido a algum contexto favorecedor ou que ocorra nos demais pronomes possessivos.

As palavras documentadas com esse ditongo são apresentadas a seguir e estão separadas da seguinte forma: em (31), estão as palavras cuja classe gramatical é verbo; em (32a-i), os não-verbos cujo contexto seguinte é a fricativa [J]; em (32a-ii) e (32a-iii), os não-verbos cujo contexto seguinte é a fricativa [ $\left[\int\right]$ como morfema de plural; em (32b), encontram-se os não verbos com o ditongo posicionado em fim de palavra e, por fim, em (32c), as palavras que sofreram monotongação:

(31) Verbos:

deu ['deṽ]

fa.le.ceu [fa.lr.'sev్ ]

mo.rreu [mo.'rev]

a.que.ceu [a.ke.'sev্]]

(32) Não-verbos:

a. Contexto seguinte: [f]

i. deus ['devf]]

ii. pneus [pr.'nev్గ]]

iii. meus ['mevf] 
b. Contexto seguinte: fim de palavra

li.ceu [li.'sev̧]

pneu [pr.'nev]

mu.seu [mu.'zev]

seu ['sev్ ]

c. Palavras monotongadas:

eu.ro ['erซ]

eu.ro.pa [e.'คว.pe]

meu ['me]

eu.ca.li.pto [e.kwa.'li.pi.tu] ${ }^{35}$

reu.ni.ão [ве.ni.'ã $\tilde{n}]$

Assim, pudemos observar que a taxa de monotongação do ditongo [ev̛] é baixa demais para poder ser feita uma análise mais apurada pelo programa Goldvarb 2001, não transparecendo que há influência de alguma variável para a aplicação ou não da monotongação. Todavia, o pronome possessivo de primeira pessoa "meu", que contém esse ditongo, apresenta um alto índice de monotongação, o que supomos ser influência do santome no PVS.

\subsubsection{Ditongo [av]}

O ditongo [av] ocorreu em 79 das 3017 palavras com ditongos. Em 89\% dessas 79 palavras, o ditongo foi mantido, sendo monotongado nos restantes $11 \%$ (os exemplos dos casos de monotongação e não monotongação são mostrados em (33) até (36)). Mais uma vez, o

\footnotetext{
${ }^{35}$ Nesse exemplo, observamos um processo de metátese no lugar da simples monotongação. O glide antes presente na primeira sílaba se move para a sílaba seguinte.
} 
elevado número de knockouts deixou o uso do Goldvarb 2001 ineficaz. No entanto, é possível fazer algumas observações por meio do uso dos filtros da tabela onde o corpus foi organizado. Nos exemplos abaixo listados, vemos que o processo de monotongação não foi aplicado, independente se a sílaba for tônica em posição inicial (33) e final (34) ou átona, como em (35):

(33) Ditongo na sílaba tônica, posição inicial:

$$
\begin{aligned}
& \text { au.la ['avִ.le] } \\
& \text { lau.ra ['lav్n.re] } \\
& \text { cau.sa ['kav.re] } \\
& \text { aos ['av్గ]] }
\end{aligned}
$$

(34) Ditongo na sílaba tônica, posição final:

Ni.co.lau [ni.kv.'lav]

ca.cau [ka.'kav]

ba.ca.lhau [ba.ka.'Kav]

(35) Ditongo na sílaba átona:

pau.la.da [paṽ.'la.de]

au.tor [avn.'tor]

(36) Ditongo formado por vocalização da lateral /l/

cal.da ['kaw.de]

No exemplo (36), vemos o processo da lateral sendo realizado como glide posterior, como acontece em muitas regiões do Brasil, no entanto, esse processo não está estabelecido no PVS. Efetivamente, é mais comum ${ }^{36}$ encontrar a realização da lateral velarizada na

\footnotetext{
${ }^{36} \mathrm{Um}$ trabalho mais detalhado sobre a aplicação do processo de vocalização da lateral /1/ em coda nas variedades do português vernacular de São Tomé e do Príncipe está sendo preparado pelo autor desta dissertação em conjunto com Ana Lívia Agostinho.
} 
posição de coda (como ocorre no PE, cf. MATEUS \& D'ANDRADE, 2000), exemplos retirados do corpus no PVS:

(37) hos.pi.tal [of.pr.'tał]

nor.mal [no.'mał]

al.ca.trão [ał.ka.'trã్̃̃ ]

Faz interessante, todavia, observar atentamente as poucas ocorrências da aplicação do processo de monotongação do ditongo [av్ ]. De forma singular em relação aos outros ditongos observados nesta dissertação, a redução do ditongo apresenta duas possibilidades. A primeira é a realização de [avn] como a vogal baixa [a], ocorrida apenas com a palavra "autor" [a'tor], a segunda, como a vogal média-alta [o], ocorridas nas palavras "Aurélio" [о'ьеlı̃ ] e "auxilia" [osi'lie] ${ }^{37}$. Esses exemplos apresentados não servem de base para apontar uma variação, uma vez que foram ocorrências únicas, todavia, existe a possibilidade de estar ocorrendo a monotongação, pois o ditongo encontra-se em contextos que favoreceram a monotongação do ditongo [eI]], visto em 3.3.1. Em um estudo sobre a redução do ditongo [ãw] postônico na morfologia verbal do PB, Silva, Fonseca \& Cantoni (2012) notaram que essa variação da redução ${ }^{38}$ do ditongo estava relacionada com questões da morfologia dos verbos e visava o nivelamento analógico de regularização das formas verbais. Todavia, os exemplos aqui apresentados não são de verbos, tampouco o ditongo se encontra em um morfema flexional. Os dados aqui apresentados são insuficientes para propor outra hipótese para essa variação da redução, assim como não se podem valer da hipótese apresentada para os verbos. Assim, os dados sugerem que são necessários mais estudos para explicar essa variação do ditongo [av్n] em não verbos.

\footnotetext{
${ }^{37}$ As palavras citadas foram realizadas múltiplas vezes por falantes distintos. ${ }^{38}$ Neste trabalho, a variação se dava entre a realização da vogal baixa [a] e a alta [u], verificou-se que a realização como vogal alta se deu pela posição átona final da palavra, contexto em que, no $\mathrm{PB}$, na maioria dos dialetos, ocorre a elevação da vogal.
} 


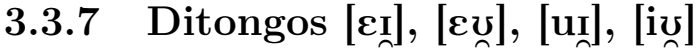

Os ditongos [eI], [عv], [uI], [iv] apareceram apenas em um grupo de palavras restrito e ocorreram apenas em seis palavras do corpus, listadas em (38), por isso ainda não é possível observar se há variação nas realizações. Nas ocorrências coletadas, não houve processo de monotongação. Em (38), estão listadas as palavras e como foram realizadas em cada ditongo citado nesse item.

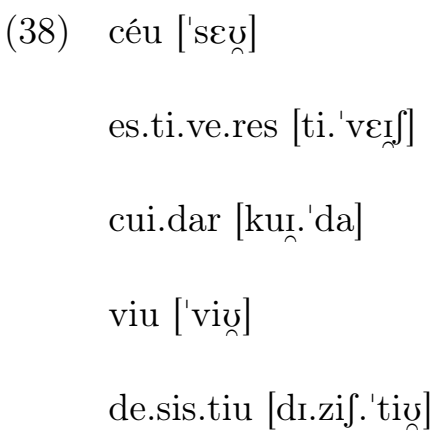

No caso da realização da palavra "estiveres", o ditongo não está na forma subjacente, porém está inserida aqui como exemplo por ter sido a única realização de [EI] até o momento observada. Também foi documentada a palavra "bacharel" [ba.fa.'rew], que, por causa da variação da aplicação da regra de vocalização da lateral na coda, formou o ditongo [عw].

Não ocorreu um exemplo para o ditongo [ơֵ]. Câmara Jr. (1995 [1970]) já observara que esse ditongo só ocorre quando há a vocalização da lateral. Como esse processo não é dominante no PVS, sua formação é mais rara. No corpus, temos o registro da palavra "sol", porém ela foi realizada como ['solv], tendo sido aplicado outro processo fonológico, a paragoge, ou seja, a inserção de uma vogal no final de palavras terminadas com sílabas fechadas, no caso do PVS, mas que também ocorre no PE, com a lateral, como nos exemplos em (39). A paragoge pode ser vista ainda como influência do santome ${ }^{39}$, já que essa língua

\footnotetext{
${ }^{39}$ Porém, como vimos no capítulo 2, a paragoge não é a única opção para a resolução da sílaba fechada em santome.
} 
evita sílabas fechadas. Abaixo são listados exemplos encontrados no corpus do PVs de Christofoletti (2011):

$$
\begin{array}{ll}
(39) \text { sol ['sə.lv] } \\
\text { Por.tu.gal [pvr.tv.'ga.li] } \\
\text { co.lo.ni.al [ko.lo.ni.'a.li] }
\end{array}
$$

Dessa forma, os ditongos apresentados nesta subseção, além de serem pouco frequentes na fala, não apresentam taxas representativas de variação. Esse fator nos impede de fazer análises estatísticas mais detalhadas para observarmos quais variáveis poderiam influenciar na aplicação ou não do processo de monotongação. Por outro lado, outros processos ligados aos ditongos formados pelo glide posterior, como a vocalização da lateral e a paragoge na sílaba final fechada por [1], trazem dados interessantes para outros estudos na área da fonética e fonologia dos ditongos do português. 


\section{Capítulo 4}

\section{Considerações finais}

O português vernacular são-tomense apresenta diversas características singulares, assim como similitudes com a variedade europeia e até mesmo com a brasileira, como se pode observar nos resultados do presente trabalho e por meio dos estudos já efetuados (FIGUEIREDO, 2008, 2009, 2010; GONÇALVES, 2010a, 2010b; CHRISTOFOLETTI, 2011; SANTOS \& CHRISTOFOLETTI, 2011). Por esse motivo, reforçamos a importância do estudo de variedades de português na África, em especial as que vivem em um ambiente de contato com outras línguas.

Observamos que alguns processos fonológicos, como a monotongação, a vocalização, a síncope, a paragoge e outros ${ }^{40}$, são documentados no PVS, assim como nas outras variedades de português. Em especial, os dados sobre o ditongo [eI] nos trouxeram resultados que justificam a pesquisa sobre a influência das línguas autóctones no português, uma vez que, nessas línguas, não são encontrados ditongos decrescentes e há uma restrição fonotática que evita o preenchimento da coda, assim, isso faz com que os glides, em determinados contextos, possam ser elididos. Também pudemos observar que a escolarização atua na realização dos ditongos, pois os dados mostraram que aqueles falantes com mais anos de escolaridade tinham porcentagens menores de aplicação da regra de monotongação, o que

${ }^{40}$ Nos trabalhos apresentados sobre as vogais do PVs, (cf. CHRISTOFOLETTI, 2010, 2011), pôde-se observar processos como elevação e harmonia vocálica, além da preferência em preservar a estrutura silábica em detrimento do apagamento da vogal nuclear da sílaba, como ocorre no PB. 
já foi atestado em outros trabalhos sobre realizações de ditongos em variedades regionais brasileiras (cf. LOPES, 2002; AMARAL, 2005; SIMIONI, 2005; CABREIRA, 2006, entre outros). O contexto singular do processo de monotongação do ditongo [eI] diante de [t] foge das explicações atuais sobre possibilidade de monotongação, pois, de acordo com Bisol (2009), as palavras "direito" e "azeite" conteriam um "ditongo verdadeiro" e, portanto, impedido de ser monotongado, assim, a hipótese possível seria a influência do contato com o santome.

Uma das variáveis que influenciam na aplicação do processo de monotongação está ligada à quantidade de anos de escolarização do falante, a qual evita a aplicação do processo quanto maior o tempo em que frequentou a escola. A exceção é o ditongo [oun], cuja aplicação do processo de monotongação é categórica, fenômeno observado em diversas variedades de português (cf. MENEGHINI, 1983; PAIVA, 1996; CABREIRA, 1996 e MOLLICA, 1998), independentemente do contexto ou número de anos de escolaridade. Contudo, cada variável linguística influencia de maneira particular cada ditongo, como podemos ver na Figura 4.1, a qual demonstra que nos níveis mais baixos de escolarização, os ditongos [eI] e [aI] possuem diferentes níveis de aplicação da monotongação, que se aproximam na faixa medial e depois caem juntos nos níveis mais altos.

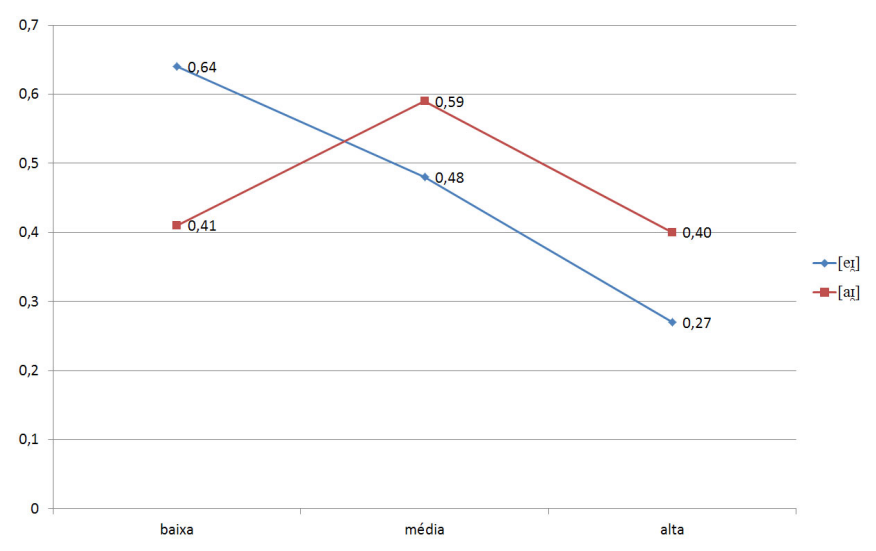

Figura 4.1: Atuação da variável escolaridade para a monotongação de [eI] e [aI] (pesos relativos). 
A seguir, retomamos os resultados detalhados no capítulo anterior. Assim, os dados aqui apresentados fornecerão maior arcabouço para o estudo da fonologia não só dessa variedade de português africano, como da língua portuguesa como um todo.

A respeito do ditongo [eI], o mais produtivo nos dados desse trabalho, verificamos que o processo de monotongação é influenciado principalmente pela presença de alveolares no contexto seguinte, pois, nessa variável, quando o ditongo é seguido por uma consoante do grupo rótico ou das fricativas alveolares, a aplicação da monotongação é próxima da categórica, resultando uma harmonia com os estudos de Paiva (1996) e Lopes (2002) para variedades brasileiras de português; contudo, quando o ditongo precede plosivas alveolares, o processo se encontra em variação estável, com peso relativo de 0,50 , resultado diferente de outras variedades do português tanto brasileiro quanto europeu, nas quais a monotongação é bloqueada diante desses fonemas. A partir dos dados desse ditongo, pudemos ainda verificar que a teoria sobre os ditongos verdadeiros e falsos propostos por Bisol (1999) é limitada, já que palavras que seriam consideradas possuidoras de ditongos verdadeiros e, portanto, não possíveis de serem monotongados, como a palavra "direito", em PVs elas monotongam. Além disso, a monotongação do [eI], diante de /t/, além de possível, está em variação estável.

No ditongo [oI], observamos que a variação na aplicação da monotongação ocorre apenas quando o ditongo é seguido pela consoante [S], a qual é a responsável pelo espraiamento do nó vocálico criando o glide [I] . Nas demais variedades do português, a monotongação de [oI] não é comum, mesmo no contexto diante de [J], a exceção encontrada foi no falar da região de Algarve, Portugal (MAIA, 1975 apud RUA, 2005).

A aplicação de monotongação do ditongo [oữ] no PVs é categórica, assim como nos estudos apresentados sobre variação na realização de ditongos de outras variedades de 
português mostradas neste trabalho no capítulo 2. A monotongação não depende sequer de anos de escolaridade e é amplamente aplicada.

O ditongo [aI] sofreu variação no processo de monotongação fundamentalmente diante da palatal, nos demais contextos, sua ocorrência foi pouco produtiva. Em final de palavra, a monotongação foi categoricamente bloqueada, assim como diante de vogais e nas formas verbais. Verificamos ainda que os resultados sobre a influência dos anos de escolaridade como inibidores do processo de monotongação ocorre também no PVs. Observamos que a fronteira morfológica influencia na aplicação do processo de monotongação, já que o processo tende a ser aplicado quando a palatal não é um morfema de plural.

O ditongo [ev̛] teve baixo índice de ocorrência de monotongação, sendo mantido em quase todos os contextos. Nos dados documentados, a monotongação ocorreu apenas no pronome "meu", o qual foi realizado como ['me]. Atribuímos esse fato a um possível processo de transposição do pronome "me" do santome, segunda língua com maior número de falantes em STP, para o português.

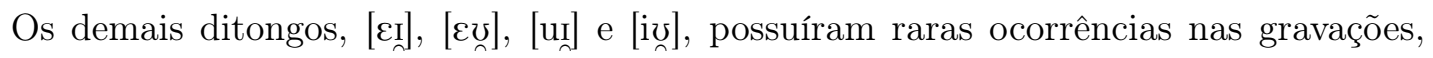
e foi impossível observar variações em suas realizações e por isso não foram analisados estatisticamente neste trabalho.

A seguir, apresentamos um quadro demonstrativo dos ditongos, se são monotongados, quais as variáveis linguísticas (VL) e extra-linguísticas (VEL) relevantes:

O que podemos observar a partir dos resultados alcançados é que os ditongos formados com glide [I] têm grandes chances de variar quando antecedem uma consoante palatal devido ao nó vocálico presente nessa consoante, assim como verificamos nos ditongos [eI], [aI] e [oI]. Nesses casos, vimos ainda que a escolaridade é a principal responsável por manter esses ditongos. Por sua vez, os ditongos formados pelo glide [ $]$ ] se comportam de formas 


\begin{tabular}{|c|c|c|c|}
\hline $\begin{array}{l}\text { Ditongo } \\
\text { [eI] }\end{array}$ & $\begin{array}{l}\text { Monotonga } \\
\text { sim }\end{array}$ & $\begin{array}{l}\text { VL } \\
\text { contexto seguinte, classe de } \\
\text { palavra, posição do ditongo, } \\
\text { tamanho da palavra }\end{array}$ & $\begin{array}{l}\text { VEL } \\
\text { escolaridade, } \\
\text { idade }\end{array}$ \\
\hline [aI] & sim & $\begin{array}{l}\text { contexto seguinte, posição do } \\
\text { ditongo }\end{array}$ & $\begin{array}{l}\text { escolaridade, } \\
\text { idade }\end{array}$ \\
\hline [OI] & $\operatorname{sim}$ & contexto seguinte & não se aplica \\
\hline [ov] & $\operatorname{sim}$ & não se aplica & não se aplica \\
\hline [ev]] & não & não se aplica & não se aplica \\
\hline [av] & não & não se aplica & não se aplica \\
\hline$[\varepsilon v],[\varepsilon \mathrm{I}],[\mathrm{i} v],[\mathrm{uI}]$ & não & não se aplica & não se aplica \\
\hline
\end{tabular}

Quadro 2: Quadro indicador das variáveis ligadas a monotongação.

distintas, podendo ser monotongados categoricamente, como o ditongo [ov], ou mantidos, como o ditongo [eṽ], sem sofrerem influência da escolaridade.

Por fim, esperamos que os resultados alcançados neste trabalho venham contribuir para ampliar não só o conhecimento das realizações dos ditongos no português de São Tomé e Príncipe e a relação deste com as demais línguas autóctones, mas principalmente abrir possibilidades de novos estudos nas variedades do português falado no continente africano como alçamento, vocalização, lateralização e outros, além de um estudo mais amplo que englobe a fonologia prosódica dessa variedade de português. 


\section{Capítulo 5}

\section{Referências bibliográficas}

AFOnsO, Beatriz. A Problemática do Bilinguismo em S. Tomé e Príncipe. In MATA, Inocência e GROSSO, Maria José (org.). Pelas Oito Partidas da Língua Portuguesa (Homenagem ao Professor João Malaca Casteleiro). Macau: Universidade de Macau/Instituto Politécnico de Macau/Departamento de LCP da FLUL, pp. 107-120. 2007.

. A problemática do bilinguismo e ensino da língua portuguesa em S. Tomé e Príncipe. Dissertação de Mestrado, Universidade Nova de Lisboa. 2008.

AGOStinho, Ana Lívia dos Santos. em preparação. Gramática Pedagógica do Principense. USP, São Paulo.

ALEXANDRE, Nélia; GONÇALVES, R.; HAGEMEIJER, T.. A formação de relativas de PP no português oral de Cabo Verde e de S. Tomé. In COSTA, Armanda; FALÉ, Isabel; BARBOSA, Pilar (org.) Textos Seleccionados do XXVI Encontro Nacional da Associação Portuguesa de Linguística. Lisboa: Edições Colibri, pp. 17-34. 2010.

AMARAL, Marisa Porto do. Ditongos variáveis no sul do Brasil. Letras de Hoje. Porto Alegre. V. 40, n. 3, p. $101-116,2005$.

ANÇÃ, Maria Helena (2002) A Língua Portuguesa em África. Revista Internacional de Língua Portuguesa, 2: 14-24, 2002.

ARAUJO, Gabriel Antunes de. Hand-outs da Disciplina de Fonologia das línguas crioulas, 2010.

Três textos em Papiamentu Clássico. Tese de Livre-docência. Universidade de São Paulo. 2011.

ARAÚJO, M. F. Ribeiro de. A alternância /ei/ - /e/ no português falado na cidade de Caxias, MA. Dissertação de Mestrado. Campinas: UNICAMP, 1999.

ARENDS, J.; MUYSKEN, P.; SMITH, N. Pidgins and Creoles: An Introduction. Amsterdam/Philadelphia: John Benjamins, 1995.

BACELAR DO NASCIMENTO, Maria Fernanda et al. The African varieties of Portuguese: compiling comparable corpora and analyzing dataderived lexicon. In: Proceedings of the Fifth International Conference on Language Resources and Evaluation, LREC 2006, pp. 1791-1794, Genoa, Italy, 22-28 May 2006. ELRA. paper.pdf: CD. 2006.

BAXTER, Alan Norman. Semicreolization? The restructured Portuguese of the Tongas 
of São Tomé, a consequence of L1 acquisition in a special contact situation. Journal of Portuguese Linguistics 1. 7-39. 2002.

The development of variable NP plural agreement in a restructured African variety of Portuguese. In: ESCURE, Geneviève; SCHEDLER, Armin (eds.). Creoles, contact and language change: Linguistics and social implications, 97-126. Amsterdam: John Benjamins. 2004.

BISOL, Leda. O ditongo em português. Boletim da ABRALIN, n. 11, p. 51-58, jun.1991.

, Leda. Ditongos derivados. DELTA, v. 10, n. especial, p. 123-140, 1994.

(Org.). Introdução a estudos de fonologia do português brasileiro. $2^{\text {a }}$ ed. Revista e ampliada. Porto Alegre: EDIPUCRS, 1999.

. A Neutralização das Átonas. Revista Letras. Curitiba: UFPR, n.61, especial, p. 273-283. 2003.

Ditongos derivados: um adendo. Slides apresentados no II SIS Vogais, Belo Horizonte 2009, disponível em: http://www.relin.letras.ufmg.br/probravo/program.htm. Acesso em: dezembro de 2012.

BONILHA, Giovana Ferreira Gonçalves. Aquisição Dos Ditongos Orais Decrescentes: Uma Análise À Luz Da Teoria Da Otimidade. Dissertação de Mestrado. Universidade Católica de Pelotas. 2000.

CABREIRA, Sílvio Henrique. A monotongação dos ditongos orais decrescentes em Curitiba, Florianópolis e Porto Alegre. Dissertação de Mestrado. Porto Alegre: PUCRS, 1996.

CÂMARA JR., Joaquim Mattoso [1970]. Estrutura da Língua Portuguesa. 23. ed. Petrópolis: Vozes. 1995.

CARDoso, M. Cabo Verde e S. Tomé e Príncipe: Educação e infra-estrutura como factores de desenvolvimento. Porto: IPAD, 2007.

CHRISTOFOLETTI, Alfredo. O sistema vocálico do português vernacular de São Tomé e Príncipe. (Relatório final) Iniciação Científica, Processo FAPESP 2010/07263-9, 2010.

Algumas observações sobre o sistema vocálico do português vernacular são-tomense. (Apresentação de Trabalho/Comunicação) III - SIS - Vogais, Porto Alegre, 2011

CINTRA, Luís F. Lindley. Estudos de dialectologia portuguesa, Editora Sá da Costa, Lisboa, 1983.

COLlischonn, Gisela. Análise prosódica da sílaba em Português. 1997. 233 fl. Tese (Linguística Aplicada) - Curso de pós-graduação em Letras, Pontifícia Universidade Católica do Rio Grande do Sul, Porto Alegre, 1997.

COUTO, H. Ditongos Crescentes e a ambissilabicidade em Português. Letras de Hoje, Porto Alegre, v.29, n. 98, p. 113-127, Dez. 1994.

EMILIANO, António. Fonética do Português Europeu: Descrição e Transcrição. Lisboa: Guimarães Editores. 2009.

ESPÍRITO SANTO, Carlos. Situação actual da língua portuguesa nas ilhas de S. Tomé 
e Príncipe. In: Congresso sobre a situação actual da língua portuguesa no mundo - Lisboa 1983. Vol. I. Lisboa: Instituto de Língua e Cultura Portuguesa, pp. 253-260. 1985.

FERGUSON, Charles A. [1959]. Diglossia. In: Language in Culture and Society, D. Hymes (ed.), 429-439. New York: Harper and Row. 1964.

FERRAZ, L.I. The Creole of Sao Tomé, Johannesburg: Witwatersrand U.P. 1979.

The liquid in the Gulf of Guinea creoles, African Studies, 46, 287-295. 1987.

FIGUEIREDO, Carlos Filipe Guimarães. A concordância variável no sintagma nominal plural do português reestruturado de almoxarife (São Tomé). PAPIA 18, p. 23-43. 2008.

A configuração do SN do português reestruturado da comunidade de Almoxarife São Tomé. Revista de Crioulos de Base Lexical Portuguesa e Espanhola, 1(1), pp. 28-55. 2009.

A concordância plural variável no sintagma nominal do português reestruturado da comunidade de almoxarife, São Tomé. Dissertação de Doutoramento, Universidade de Macau(download). 2010.

Variável extralinguística escolaridade: influência na marcação plural do sintagma nominal do português reestruturado de almoxarife, São Tomé. PAPIA 22(1). 2012.

GUY, G. R. \& ZILLES, A. Sociolingüística quantitativa. Instrumental de análise. São Paulo: Parábola, 2007.

GÜNTHER, Wilfried. Das portugiesische Kreolisch der Ilha do Príncipe. Marburg an der Lahn: Im Selbstverlag. 1973.

GONÇALVES, R. M. G. Propriedades de subcategorização verbal no português de São Tomé. Dissertação de mestrado, Universidade de Lisboa, 2010a.

A preposição a no português de S. Tomé. In Ana Maria Brito; Fátima Silva; João Veloso e Alexandra Fiéis (org.). Textos Seleccionados do XXV Encontro Nacional da Associação Portuguesa de Linguística 2009. Lisboa: Edições Colibri, pp.475-486, 2010b.

GOVERNO DE SÃO TOMÉ E PRÍNCIPE. Sobre o país: Factos e História do País. Disponível em: <http://www.gov.st/data/filestorage/docs/sobrestp02.htm Acesso em: 12 abr. de 2010.

GRAHAM, Steve \& GRAHAM, Trina. West Africa lusolexed creoles word list file. documentation. SIL Electronic Survey Reports 2004-012. 24, 20p. Disponivel em http://www.sil.org/silesr/abstract.asp?ref=2004-012. Acesso em: dezembro 2012.

HAGEMEIJER, Tjerk. As línguas de S. Tomé e Príncipe. In: Revista de Crioulos de Base Lexical Portuguesa e Espanhola. 1(1), (27 pgs). 2009.

Tjerk. "The Gulf of Guinea Creoles: genetic and typological relations". Journal of Pidgin and Creole Languages. 2011.

HAGEMEIJER, Tjerk; ARAUJO, Gabriel Antunes de; BHATT, Parth;(em preparação). Revisiting the liquid consonants in the Gulf of Guinea creoles. 2013.

HOLM, John; MADEIRA, Sandra. À propos des noms de variétés du portugais restructuré em Afrique. In: Féral, C. de. (ed.) Le nom des langues III. Le nom des langues 
en Afrique sub-saharienne: pratiques, denominations, catégorisations. Naming Languages in Sub-Saharan Africa: Practices, Names, Categorisations, bcill 124: 109-118. Louvain-la-Neuve: Peeters. 2009.

INSTITUTO NACIONAL DE ESTATÍSTICA, [2001]. INE: São Tomé e Príncipe em Números. Disponível em: http://www.ine.st/files_pdf/STP_numeros_2006.pdf Acesso em: 12 abr. de 2010.

[2012]. INE: São Tomé e Príncipe em Números. Disponível em: http://www.ine.st/docs/2012/Censos/2012/index.html Acesso em: 04 mar. de 2013.

LABOV, William (1972). Sociolinguistic Patterns. 11th printing. Philadelphia: University of Pennsylvania Press, 1991

LEIRIA, Lúcia L. A ditongação variável em sílabas tônicas travadas por /S/. Dissertação de Mestrado. Pontifícia Universidade Católica do Rio Grande do Sul. Porto Alegre. 1995.

LENZI, M. C.; BRENNER, T. M. Análise das vogais postônicas finais [e] e [o] nos falantes do município de Doutor Pedrinho. Work. pap. linguíst., 9 (1), Florianópolis, jan. jun., p. 55-62. 2008

LOPES, Raquel. A realização variável dos ditongos /ow/ e /ej/ no português falado em Altamira/PA. Dissertação de Mestrado. Universidade Federal do Pará. 2002 .

LORENZINO, Gerardo. A. Uma avaliação sociolinguística sobre São Tomé e Príncipe. In: DUARTE, Inês; LEIRIA, Isabel (org.), Actas do Congresso Internacional sobre o Português, Vol. II. Lisboa: APL e Edições Colibri, pp. 435-449. 1996.

LUCCHESI, Dante; BAXTER, Allan; RIBEIRO, Ilza. O português afro-brasileiro. Salvador: Editora da UFBA. 2009.

MATEUS, Maria Helena; D'ANDRADE Ernesto. The Phonology of Portuguese. New York: Oxford University Press. 2000.

MAURER, Philippe. L'Angolar. Londres: Battlebridge Publications, 1995

Principense (Lung'ie). Grammar, texts, and vocabulary of the afro-Portuguese creole of the island of Principe, Gulf of Guinea. Battlebridge. 2009.

MENEGHINI, F. O fenômeno da monotongação em lbiaça, Rio Grande do Sul. Dissertação de mestrado. Porto Alegre: PUCRS, 1983.

MOLLICA, M. C. Influência da fala na alfabetização. Rio de Janeiro: Tempo Brasileiro, 1998.

MUYSKEN, P., \& SMITH, N. The study of pidgin and creole languages. In: Arends, J.; Muysken, P.; Smith, N (eds.), Pidgins and creoles: An introduction. Amsterdam: John Benjamins, (pp. 3-14), 1995.

NARO, Anthony. O dinamismo das línguas. In: MOLLICA, Cecília; BRAGA, Maria Luiza. Introdução à sociolinguística. São Paulo: Contexto. pp. 43-50. 2003.

NARO, Anthony Julius; SCHERRE, Maria Marta Pereira. Origens do português brasileiro. São Paulo: Parábola Editorial, 2010.

PAGOTTO, Emílio Gozze. Variação e Identidade. UFAL, 2004. 
PAIVA, Maria da Conceição A. A supressão das semi vogais nos ditongos decrescentes. In: SHERRE, Maria M. P. et al. (org.) Padrões sociolingüísticos: análise de fenômenos variáveis do português falado na cidade do Rio de Janeiro. Rio de Janeiro: Tempo Brasileiro: Departamento de Lingüística e Filologia, UFRJ, pp. 218-236, 1996.

POLYCARPO, Nathaschka M. As consoantes do português vernacular sãotomense. Em preparação.

RAND, D. \& SANKOFF, D. GoldVarb: a variable rule application for Macintosh. 1990.

ROBINSON, John; LAWRENCE, Helen \& TAGLIAMONTE, Sali. GoldVarb 2001: A Multivariate Analysis Application for Windows. User's manual. October 2001.

ROUGÉ, Jean-Louis. Les langues des Tonga. In ANDRADE, Ernesto de, MOTA, Maria Antónia e PEREIRA, Dulce (eds.). Actas do colóquio sobre crioulos de base lexical portuguesa, pp 171-176. Lisboa: Colibri, 1992.

, Jean-Louis. Dictionnaire étymologique des créoles portugais d'Afrique. Paris: Karthala, 2004.

RUA, Carla Marina Amorim Tavares. Ditongos Orais no Português Europeu. Dissertação de mestrado. Universidade de Aveiro, 2005.

SAntos, E. F. \& CHRistofoletti, A. A Palavra Prosódica no Português Vernacular de São Tomé e Príncipe e no Português de Angola: Uma Análise Preliminar. (Apresentação de Trabalho/Comunicação) - II Simpósio Internacional do GELIC, Vitória - ES, 2011.

SILVA, Fabiana de Souza. O processo de monotongação em João Pessoa. Dissertação de Mestrado. João Pessoa: UFPB, 1997.

SILVA, S. M. Alçamento das vogais médias átonas finais no português falado em Rincão Vermelho-RS. Revista Língua \& Literatura. 11n. 17, Dez. pp. 211-234. 2009.

SILVA, Rosa Virgínia Mattos e. O português arcaico: fonologia, morfologia e sintaxe. São Paulo: Contexto, 2006.

SILVA, Thaïs Cristófaro. Nuclear Phenomena in Brazilian Portuguese. Tese. Universidade de Londres, Londres, 1992.

Fonética e Fonologia do Português. São Paulo: Contexto, 2010.

Dicionário de fonética e fonologia. São Paulo: Contexto, 2011.

SILVA, T. C.; FONSECA, M. S.; CANTONI, M. A redução do ditongo [ãw] postônico na morfologia verbal do português brasileiro: uma abordagem baseada no uso. Letras de Hoje, Porto Alegre, v. 47, n. 3, p. 283-292, jul./set. 2012.

SIMIONI, Taíse. A alternância entre ditongo crescente e hiato em Português: Uma análise Otimalista. Dissertação de mestrado. Porto Alegre. 2005

TEYSSIER, P [1989]. História da língua portuguesa. $2^{\mathrm{a}}$ ed. São Paulo: Martins Fontes, 2001.

TONELI, P. M. O comportamento prosódico de palavras compostas no Português Brasileiro. I Congresso Nacional de Estudos Linguísticos, Vitória-Es, 18 a 21 de Outubro, 2011.

VAUX; COOPER; TUCKER. Linguistic Field Methods. Oregon: Wipf \& Stock. 2007. 
VIGÁRIO, M. Palavra prosódica e composição no Português Europeu. In: CASTRO, R. V.; BARBOSA, P. (orgs.) Actas do XV Encontro da Associação Portuguesa de Linguística, Vol. 2. Coimbra: APL, 583-602, 1999.

M. The Prosodic Word in European Portuguese. Berlin/New York: Mouton de Gruyter, 2003. Ph.D. Thesis. Lisboa: University of Lisboa, 2001.

M. O lugar do Grupo Clítico e da Palavra Prosódica Composta na hierarquia prosódica: uma nova proposta. In: LOBO \& COUTINHO (orgs.): Actas do XXII Encontro Nacional da Associação Portuguesa de Lingüística - Textos seleccionados. Lisboa: Colibri Artes Gráficas, 673-688, 2007.

WARDHAUGH, Ronald. An introduction to sociolinguistics. Oxford: Blackwell. 1995. 


\section{Apêndice A}

\section{Corpus}

A seguir apresento um exemplo da tabela contendo os dados utilizados para a análise apresentada neste trabalho. É possível observar que nesta tabela estão presentes realizações dos ditongos nasais, pois esses dados serão utilizados futuramente para a observação desses ditongos e, portanto, foram inseridos na tabela.

\begin{tabular}{|c|c|c|c|c|c|c|c|c|c|c|c|c|c|c|c|}
\hline Palavra & T.F. & Tempo & $\#$ & $\mathbf{V}$ & G & $\begin{array}{l}\text { C } \\
\text { S }\end{array}$ & $\begin{array}{l}\text { C } \\
\text { a }\end{array}$ & Po & $\begin{array}{l}\text { P. } \\
\text { S }\end{array}$ & M & $\begin{array}{l}\mathbf{P} \\
\mathbf{F}\end{array}$ & Id. & Es & Se & Info. \\
\hline acoplação & [akopla'sãu] & $\begin{array}{r}00: 05: 5 \\
1\end{array}$ & 1 & $\mathrm{a}$ & $\mathrm{w}$ & $\mathrm{z}$ & $\mathrm{n}$ & 3 & $\mathrm{t}$ & $\mathrm{b}$ & 0 & 1 & $\mathrm{~d}$ & $\mathrm{f}$ & ASS \\
\hline cacau & [ka’kau] & $\begin{array}{r}00: 30: 1 \\
8\end{array}$ & 1 & $\mathrm{a}$ & $\mathrm{w}$ & $\mathrm{z}$ & $\mathrm{n}$ & 3 & $\mathrm{t}$ & $\mathrm{b}$ & 0 & 1 & $\mathrm{~d}$ & $\mathrm{f}$ & ASS \\
\hline calda & ['kaunde] & $\begin{array}{r}00: 28: 2 \\
5\end{array}$ & 1 & $\mathrm{a}$ & $\mathrm{w}$ & $\mathrm{z}$ & $\mathrm{n}$ & 1 & $\mathrm{t}$ & $\mathrm{b}$ & 0 & 1 & $\mathrm{~d}$ & $\mathrm{f}$ & ASS \\
\hline creio & ['kreñu] & $\begin{array}{r}00: 00: 5 \\
1\end{array}$ & 1 & $\mathrm{e}$ & $\mathrm{y}$ & $\mathrm{z}$ & $\mathrm{v}$ & 1 & $\mathrm{t}$ & $\mathrm{b}$ & 0 & 1 & $\mathrm{~d}$ & $\mathrm{f}$ & ASS \\
\hline cuidar & [kurn’da] & $\begin{array}{r}00: 55: 1 \\
6\end{array}$ & 1 & $\mathrm{u}$ & $\mathrm{y}$ & $\mathrm{z}$ & $\mathrm{v}$ & 1 & $\mathrm{p}$ & $\mathrm{b}$ & 0 & 1 & $\mathrm{~d}$ & $\mathrm{f}$ & ASS \\
\hline maior & [mar్r’or] & $\begin{array}{r}00: 00: 5 \\
2\end{array}$ & 1 & $\mathrm{a}$ & $\mathrm{y}$ & $\mathrm{v}$ & $\mathrm{n}$ & 1 & $\mathrm{p}$ & $\mathrm{b}$ & 0 & 1 & $\mathrm{~d}$ & $\mathrm{f}$ & ASS \\
\hline noite & ['norttI] & $\begin{array}{r}00: 01: 3 \\
5\end{array}$ & 1 & 0 & $\mathrm{y}$ & $\mathrm{z}$ & $\mathrm{n}$ & 1 & $\mathrm{t}$ & $\mathrm{b}$ & 0 & 1 & $\mathrm{~d}$ & $\mathrm{f}$ & ASS \\
\hline palaiê & [palarr’e] & $\begin{array}{r}00: 56: 1 \\
2\end{array}$ & 1 & $\mathrm{a}$ & $\mathrm{y}$ & $\mathrm{v}$ & $\mathrm{n}$ & 2 & $\mathrm{p}$ & $\mathrm{b}$ & 0 & 1 & $\mathrm{~d}$ & $\mathrm{f}$ & ASS \\
\hline passagem & [pa'sazẽ̃̃I] & $\begin{array}{r}00: 15: 4 \\
7\end{array}$ & 1 & $\mathrm{e}$ & $\mathrm{y}$ & $\mathrm{n}$ & $\mathrm{n}$ & 3 & $\mathrm{f}$ & $\mathrm{b}$ & 0 & 1 & $\mathrm{~d}$ & $\mathrm{f}$ & ASS \\
\hline reino & ['yemü] & $\begin{array}{r}00: 39: 5 \\
8\end{array}$ & 1 & $\mathrm{e}$ & $\mathrm{y}$ & $\mathrm{z}$ & $\mathrm{n}$ & 1 & $\mathrm{t}$ & $\mathrm{b}$ & 0 & 1 & $\mathrm{~d}$ & $\mathrm{f}$ & ASS \\
\hline alcatrão & [ałka’trãu] & $\begin{array}{r}00: 04: 4 \\
2\end{array}$ & 1 & $\mathrm{a}$ & $\mathrm{w}$ & $\mathrm{z}$ & $\mathrm{n}$ & 3 & $\mathrm{t}$ & $\mathrm{b}$ & 0 & 2 & $\mathrm{c}$ & $\mathrm{m}$ & CAS \\
\hline coiso & ['koIzu] & $\begin{array}{r}00: 04: 4 \\
1\end{array}$ & 1 & o & $\mathrm{y}$ & $\mathrm{z}$ & $\mathrm{n}$ & 1 & $\mathrm{t}$ & $\mathrm{b}$ & 0 & 2 & $\mathrm{c}$ & $\mathrm{m}$ & CAS \\
\hline coragem & [ku'razẽ İ] & $\begin{array}{r}00: 02: 3 \\
8\end{array}$ & 6 & $\mathrm{e}$ & $\mathrm{y}$ & $\mathrm{n}$ & $\mathrm{n}$ & 3 & $\mathrm{f}$ & $\mathrm{b}$ & 0 & 2 & $\mathrm{c}$ & $\mathrm{m}$ & CAS \\
\hline deu & ['deun] & $\begin{array}{r}00: 01: 4 \\
2\end{array}$ & 1 & $\mathrm{e}$ & $\mathrm{w}$ & $\mathrm{z}$ & $\mathrm{v}$ & 1 & $\mathrm{t}$ & $\mathrm{b}$ & 0 & 2 & $\mathrm{c}$ & $\mathrm{m}$ & CAS \\
\hline escorreguei & [Ifkure'ger] & $\begin{array}{r}00: 00: 2 \\
9\end{array}$ & 3 & $\mathrm{e}$ & $\mathrm{y}$ & $\mathrm{z}$ & $\mathrm{v}$ & 3 & $\mathrm{t}$ & $\mathrm{b}$ & 0 & 2 & $\mathrm{c}$ & $\mathrm{m}$ & CAS \\
\hline faleceu & [falı'seu] & $\begin{array}{r}00: 14: 0 \\
3\end{array}$ & 1 & $\mathrm{e}$ & $\mathrm{w}$ & $\mathrm{z}$ & $\mathrm{v}$ & 3 & $\mathrm{t}$ & $\mathrm{b}$ & 0 & 2 & $\mathrm{c}$ & $\mathrm{m}$ & $\overline{\text { CAS }}$ \\
\hline frio & ['friug] & $\begin{array}{r}00: 03: 3 \\
3\end{array}$ & 3 & $i$ & $\mathrm{w}$ & $\mathrm{z}$ & $\mathrm{n}$ & 1 & $\mathrm{t}$ & $\mathrm{b}$ & 0 & 2 & $\mathrm{c}$ & $\mathrm{m}$ & $\overline{\text { CAS }}$ \\
\hline morreu & [mo'reu] & $\begin{array}{r}00: 07: 4 \\
9\end{array}$ & 1 & $\mathrm{e}$ & $\mathrm{w}$ & $\mathrm{z}$ & $\mathrm{v}$ & 3 & $\mathrm{t}$ & $\mathrm{a}$ & 0 & 2 & $\mathrm{c}$ & $\mathrm{m}$ & CAS \\
\hline oitos & ['ottuf] & $\begin{array}{r}00: 04: 1 \\
6\end{array}$ & 1 & o & $y$ & $\mathrm{z}$ & $\mathrm{n}$ & 1 & $t$ & $\mathrm{~b}$ & 0 & 2 & $\mathrm{c}$ & $\mathrm{m}$ & CAS \\
\hline óleo & ['oliun] & $\begin{array}{r}00: 10: 1 \\
2\end{array}$ & 1 & I & $\mathrm{w}$ & $z$ & $n$ & 3 & $\mathrm{f}$ & $\mathrm{b}$ & 0 & 2 & $\mathrm{c}$ & $\mathrm{m}$ & CAS \\
\hline tábuas & ['taburef] & $\begin{array}{r}00: 01: 3 \\
0\end{array}$ & 1 & $\mathrm{a}$ & $\mathrm{w}$ & $\mathrm{z}$ & $\mathrm{n}$ & 3 & $\mathrm{t}$ & $\mathrm{b}$ & 0 & 2 & $\mathrm{c}$ & $\mathrm{m}$ & CAS \\
\hline violência & [vio'lẽsı̃e] & $\begin{array}{r}00: 17: 2 \\
3\end{array}$ & 1 & i & $\mathrm{y}$ & $\mathrm{z}$ & $\mathrm{n}$ & 3 & $\mathrm{p}$ & $\mathrm{b}$ & 0 & 2 & $\mathrm{c}$ & $\mathrm{m}$ & CAS \\
\hline cacau & [ka’kau] & $\begin{array}{r}00: 30: 1 \\
7\end{array}$ & 1 & $\mathrm{a}$ & $\mathrm{w}$ & $\mathrm{z}$ & $\mathrm{n}$ & 3 & $\mathrm{t}$ & $\mathrm{b}$ & 0 & 3 & $\mathrm{~b}$ & $\mathrm{~m}$ & $\mathrm{AA}$ \\
\hline
\end{tabular}

